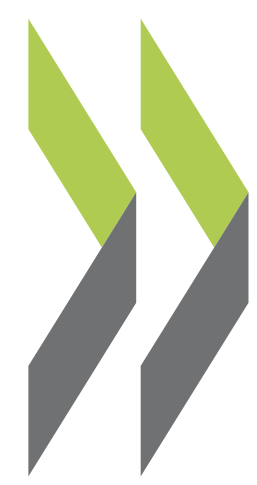

OECD Economics Department Working Papers No. 1588

$$
\begin{array}{r}
\text { Housing, wealth } \\
\text { accumulation and wealth } \\
\text { distribution: Evidence } \\
\text { and stylized facts }
\end{array}
$$

Orsetta Causa,

Nicolas Woloszko, David Leite 
HOUSING, WEALTH ACCUMULATION AND WEALTH DISTRIBUTION: EVIDENCE AND STYLIZED FACTS

\section{ECONOMICS DEPARTMENT WORKING PAPERS No. 1588}

\section{By Orsetta Causa, Nicolas Woloszko and David Leite}

OECD Working Papers should not be reported as representing the official views of the OECD or of its member countries. The opinions expressed and arguments employed are those of the author(s).

Authorised for publication by Alain de Serres Deputy Director, Policy Studies Branch, Economics Department.

All Economics Department Working Papers are available at www.oecd.org/eco/workingpapers.

JT03456124 
OECD Working Papers should not be reported as representing the official views of the OECD or of its member countries. The opinions expressed and arguments employed are those of the author(s).

Working Papers describe preliminary results or research in progress by the author(s) and are published to stimulate discussion on a broad range of issues on which the OECD works.

Comments on Working Papers are welcomed, and may be sent to OECD Economics Department, 2 rue André Pascal, 75775 Paris Cedex 16, France, or by e-mail to eco.contact@oecd.org.

All Economics Department Working Papers are available at www.oecd.org/eco/workingpapers

This document and any map included herein are without prejudice to the status of or sovereignty over any territory, to the delimitation of international frontiers and boundaries and to the name of any territory, city or area.

\section{(c) OECD (2019)}

You can copy, download or print OECD content for your own use, and you can include excerpts from OECD publications, databases and multimedia products in your own documents, presentations, blogs, websites and teaching materials, provided that suitable acknowledgment of OECD as source and copyright owner is given. All requests for commercial use and translation rights should be submitted to rights@oecd.org 


\section{ABSTRACT/RÉSUMÉ}

\section{Housing, wealth accumulation and wealth distribution: evidence and stylized facts}

This paper produces new evidence and stylised facts on housing, wealth accumulation and wealth distribution, relying on an in-depth analysis of micro-based data on household wealth across OECD countries. The analysis addresses several questions: i) How is homeownership and housing tenure distributed across the population along various socioeconomic characteristics such as income, wealth and age? What is the weight of housing in households' balance sheets and how does this vary across socio-economic groups? ii) What is the incidence of mortgage debt across households and how does this vary across socio-economic groups? What is the impact of mortgage debt on access to homeownership and wealth accumulation, and on debt overburden and financial risks among vulnerable groups? iii) Is housing a vehicle for wealth accumulation? Can it be a barrier to residential mobility? iv) Is there a link between homeownership and wealth inequality? Between inequality in housing wealth and in total wealth? A key policy issue addressed in this paper is whether and how housing-related policies affect wealth distribution. Another important issue is whether housing-related policies raise potential trade-offs between equity, or inequality reduction, and other policy objectives such as employment and productivity growth as well as macroeconomic resilience. Informed by the stylised facts and existing evidence, this paper discusses preliminary policy implications of housing reform to promote inclusiveness and social mobility, to enhance efficiency in the allocation of labour and capital and to strengthen macroeconomic resilience.

JEL codes: D14, D15, D31, D64, E21, G21, H24, J61.

Keywords: housing, wealth distribution, wealth accumulation, intergenerational wealth transfers, mortgage debt, household portfolio, inequality, mobility, taxes, progressivity, prudential regulation.

\section{Logement, accumulation de patrimoine et distribution du patrimoine : données et faits stylisés}

Ce rapport présente des données et faits stylisés nouveaux sur le logement, l'accumulation de patrimoine et la distribution du patrimoine, en s'appuyant sur une analyse approfondie de microdonnées relatives au patrimoine des ménages dans les pays de l'OCDE. Cette analyse vise à répondre à plusieurs questions : i) Comment sont répartis l'accession à la propriété et les modes d'occupation des logements dans la population selon différentes caractéristiques socioéconomiques comme le revenu, le patrimoine et l'âge ? Quelle est la charge financière représentée par le logement pour les ménages et dans quelle mesure varie-t-elle en fonction des catégories socioéconomiques ? ii) Quelle est l'incidence de la dette hypothécaire parmi les ménages et quelles sont les variations constatées à cet égard en fonction de la situation socioéconomique ? Quel est l'impact de la dette hypothécaire en matière d'accession à la propriété et d'accumulation de patrimoine, ainsi que de surendettement et de risques financiers pour les groupes vulnérables ? iii) Le logement est-il un moyen d'accumuler du patrimoine ? Peut-il constituer un obstacle à la mobilité résidentielle ? iv) Existe-t-il un lien entre l'accession à la propriété et les inégalités de patrimoine ? Et entre les inégalités en matière de patrimoine résidentiel et les inégalités au regard du patrimoine total ? L'une des principales problématiques pour l'action publique abordée dans ce rapport est la question de savoir si les politiques relatives au logement influent sur la distribution du patrimoine, et comment. Autre enjeu majeur : les politiques relatives au logement sont-elles à l'origine d'arbitrages potentiels entre les objectifs d'équité ou de réduction des inégalités d'une part, et d'autres objectifs de l'action publique d'autre part, comme la croissance de l'emploi et de la productivité ou la résilience macroéconomique. En s'appuyant sur des faits stylisés et des données existantes, ce rapport examine les premières implications pour l'action publique des réformes menées dans le domaine du logement en vue de promouvoir l'inclusivité et la mobilité sociale, d'optimiser l'efficience de l'allocation de la main-d'œuvre et du capital, et de renforcer la résilience macroéconomique.

Codes JEL : D14, D15, D31, D64, E21, G21, H24, J61.

Mots clés : logement, distribution du patrimoine, accumulation de patrimoine, transferts intergénérationnels de patrimoine, dette hypothécaire, portefeuille des ménages, inégalités, mobilité, impôts, progressivité, réglementation prudentielle. 


\section{Table of Contents}

1. Housing, wealth accumulation and wealth distribution: evidence and stylized facts .................. 7

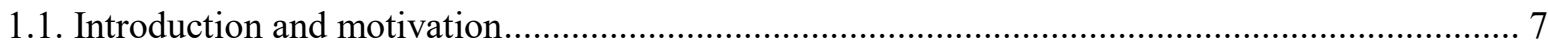

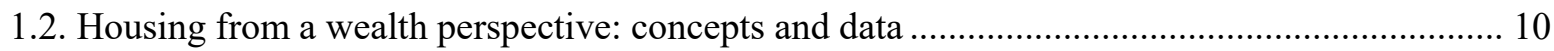

1.2.1. The framework for micro statistics on wealth and housing wealth: a brief overview.......... 10

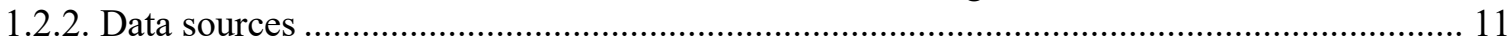

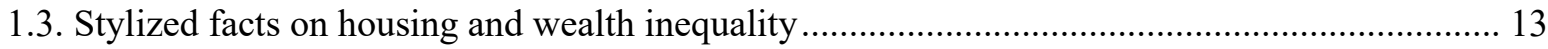

1.3.1. Prologue and motivation: wealth relative to income inequality .......................................... 13

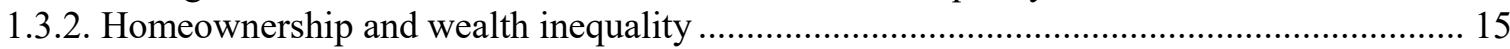

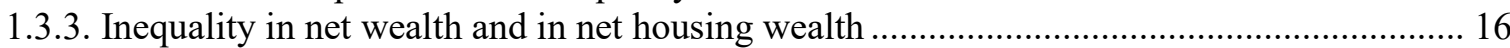

1.4. Stylized facts on homeownership, housing assets, housing liabilities and wealth accumulation 20

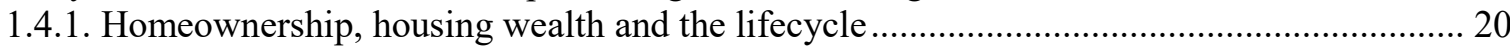

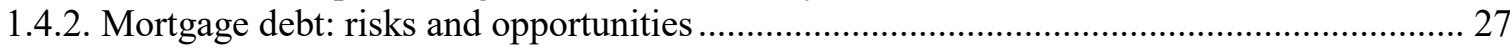

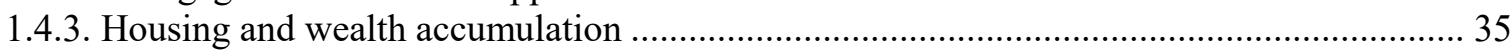

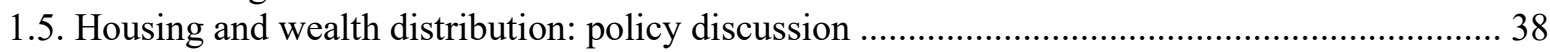

1.5.1. Reforming property taxes to make the overall tax system more progressive and efficient . 39

1.5.2. Housing policy reforms to promote resilience and labour mobility ..................................... 49

1.6. Wrapping-up: a snapshot of countries' relative positions on housing and wealth distribution .. 54

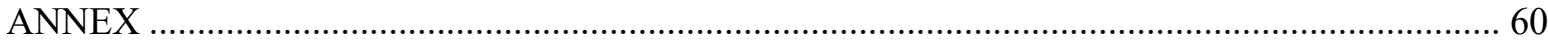

Annex A 2.1.1 Housing from a wealth distribution perspective: additional details on data and

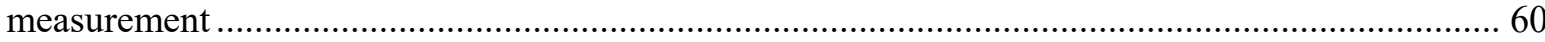

Additional details on the micro-sources used in the paper: HFCS and LWS............................... 61

A technical note on the use of semi-aggregated data for analysing household wealth and its

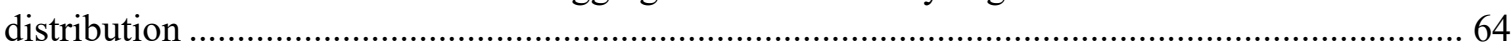

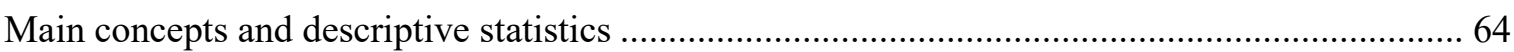

Annex B 2.1.2 Some preliminary evidence on housing and wealth inequality over time ................ 67

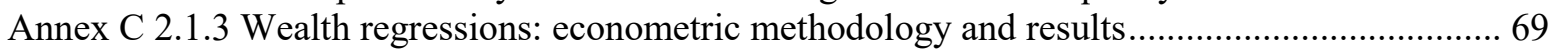

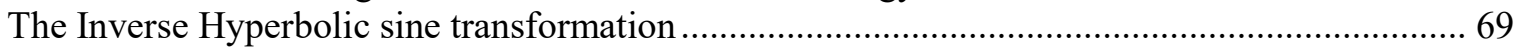

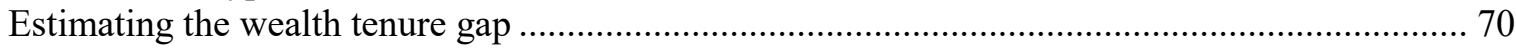

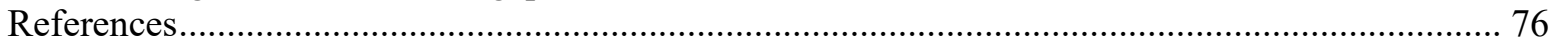

Tables

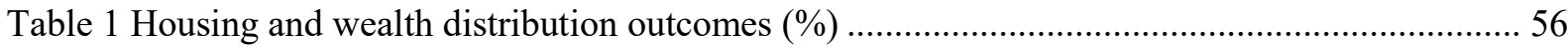

Table 2 Housing and wealth distribution outcomes pairwise correlations ............................................ 58

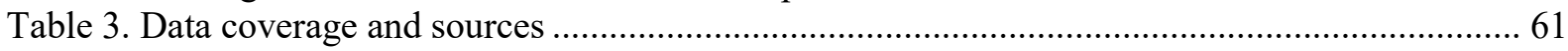

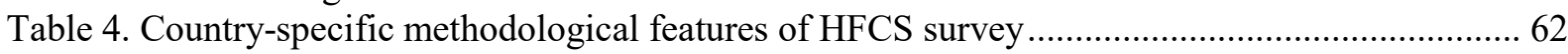

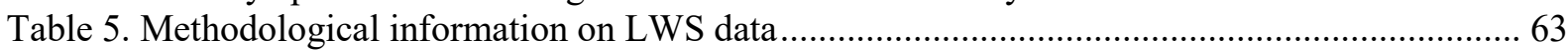

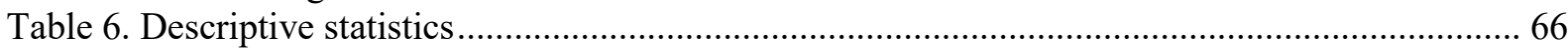

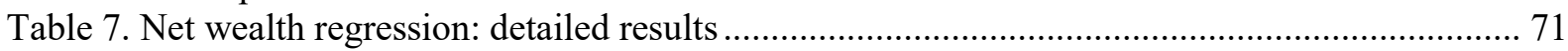

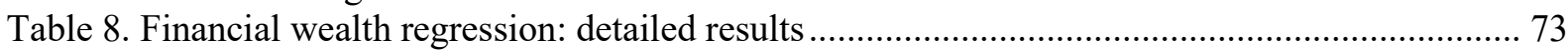

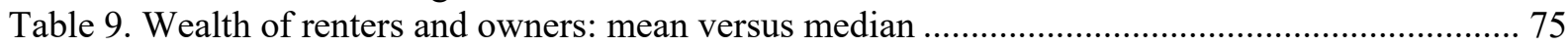

Figures 
Figure 1. Wealth inequality is much higher as well as much more dispersed across countries than income inequality..... 14

Figure 2. High-homeownership countries tend to exhibit low wealth inequality..... 16

Figure 3 . Net wealth inequality and net housing wealth inequality are highly correlated across countries

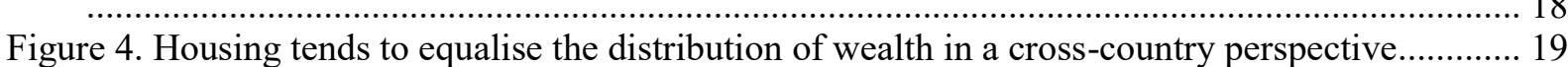

Figure 5. OECD countries exhibit great variation in the housing tenure mix ....................................... 20

Figure 6. Households' characteristics in terms of age and size are major drivers of housing tenure .... 21

Figure 7. High homeownership countries exhibit low income spread but not necessarily low wealth spread

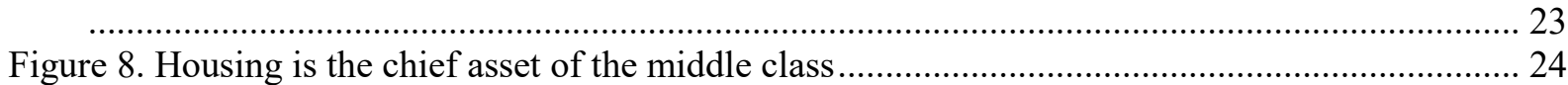

Figure 9. Housing wealth tends to be hump-shaped across the lifecycle, but with large cross-country

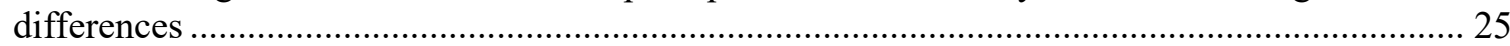

Figure 10. There is no systematic link between homeownership and public pension generosity ......... 27

Figure 11. At the macro and household level, mortgage debt is the largest part of household debt .... 28

Figure 12. OECD countries exhibit great variation in households' participation in the mortgage market, and participation increases with the level of household income

Figure 13. Participation in the mortgage market by young households tends to narrow the difference between homeownership among young and the rest of the population...... 30

Figure 14. Mortgage debt can expose households to financial vulnerability 31

Figure 15. The use of the primary house as collateral is relatively uncommon in most OECD countries 33

Figure 16. Purchasing another real estate asset tends to be a major purpose for using the primary house as collateral in European countries 34

Figure 17. Ownership of secondary houses is concentrated at the top of the distribution .................... 35

Figure 18. Homeowners tend to be wealthier than renters .............................................................. 36

Figure 19. The tenure wealth gap declines significantly in a micro-based regression framework....... 37

Figure 20. OECD countries have ample room to shift the tax burden towards property taxes ........... 40

Figure 21. Some countries could move away from taxing income to taxing immovable property and

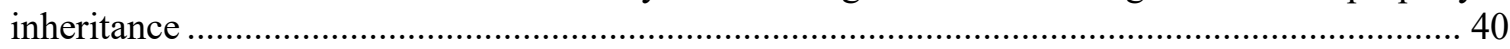

Figure 22. Owner-occupied property taxes could be made more progressive ................................... 41

Figure 23. Higher progressivity in the tax system could be achieved by raising owner-occupied property taxes at high-income levels while reducing labour taxation at low-income levels

Figure 24. Household main residence and other real estate: a tale of two inequalities .............................4 44

Figure 25. High-income households have much higher chances of inheriting other assets than the main residence. 45

Figure 26. Across European countries, housing inheritance is negatively correlated with inheritance tax revenues 46

Figure 27. Being homeowner reduces the risk of being asset-poor but not the risk of being income-poor 48

Figure 28. Homeowners are over-represented among the income-poor in some OECD countries....... 48

Figure 29. In most European countries, more than one in five low-income homeowners have inherited their house.....

Figure 30. Across European countries, high homeownership is associated with low residential mobility51

Figure 31. Owner-occupied households tend to be less mobile than renters...................................... 52

Figure 32. Excessive rental market regulation may hamper residential mobility ................................. 53

Figure 33: A snapshot of countries' relative positions on housing and wealth (normalised indicators):

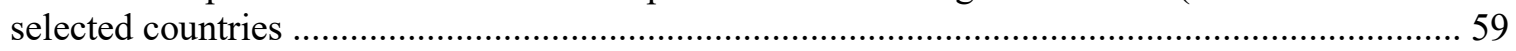

Figure 34. Developments in homeownership and house prices can affect wealth inequality ............... 68

Boxes 


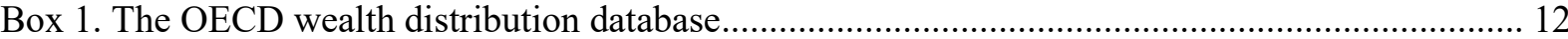

Box 2. The contribution of housing to wealth inequality: a simple illustrative exercise ...................... 19

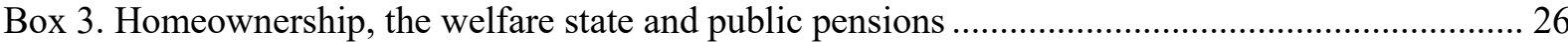

Box 4. Some insights on the use of the primary house as collateral ................................................. 32 


\title{
1. Housing, wealth accumulation and wealth distribution: evidence and stylized facts
}

\author{
By Orsetta Causa, Nicolas Woloszko and David Leite ${ }^{1}$
}

\subsection{Introduction and motivation}

Housing is important for people well-being along several dimensions such as access to affordable housing for different socioeconomic groups, the impact of housing on poverty and deprivation risks as well spatial inequalities including housing segregation in metropolitan areas. One important dimension that has been less explored is the distributional implications of housing from a wealth perspective. This paper delivers new evidence on housing and wealth distribution across OECD countries. ${ }^{2}$

Housing and wealth distribution warrants attention for several reasons. Housing is the largest asset in household portfolios. It is therefore a fundamental driver of the accumulation and the distribution of assets and wealth across the lifecycle and across generations, hence contributing to wealth inequality. Assessing housing from a wealth distribution perspective is all the more important in a context where inequality has been rising, where the capital share of income has increased relative to labour and where wealth inequality is much higher than income inequality, potentially undermining equality of opportunity and social mobility (OECD, 2018 $\left.8_{[1]}\right)$.

Housing debt is also the largest liability in household portfolios. One of the reasons why housing is a major vehicle of wealth accumulation is because it can be acquired with leverage. Housing-related debt allows households with low income and little assets, for example young households, to accumulate wealth. The benefits of leverage need to be balanced against its risks, and that is one major lesson from the 2008 financial crisis. Assessing housing from a wealth distribution perspective requires looking at housing assets and liabilities, with a particular attention to the bottom of the income and wealth distributions.

\footnotetext{
${ }^{1}$ The authors thank Asa Johannsson from the OECD Economics Department for her full engagement in this project, for the valuable discussions, for her suggestions, inputs and comments from the beginning of the analysis until the drafting of the paper. The authors wish to thank Thierry Hounsa for his key contribution to the analysis of LWS data. They thank Carlotta Balestra from the OECD Statistics Directorate for her continuous cooperation, support and advice on WDD data and for drafting Box 1. They also owe a lot to Piotr Paradowski from the Luxembourg Income Study for his generous and precious help for manipulating LWS data remotely. They thank Pierce O'Reilly, Sarah Perret and Bert Brys from the OECD Centre for Taxation policy for collaboration and valuable discussions on the tax policy assessment in the paper. They thank Sebastian Konings and Marissa Plouin from the OECD Employment, Labour and Social Affairs directorate and colleagues from the OECD Economics Department Christophe André, Alain de Serres, Luiz de Mello as well as participants in the Working Party No. 1 of the Economic Policy Committee for useful comments and suggestions.

2 The current housing project builds on a past OECD projects on housing e.g. (Andrews, Caldera Sánchez and Johansson, 2011 $1_{[11]}$ ) and (Catte et al., 2005 [60] $)$. See also for (Cournede, B. , V. Ziemman and Sarha Sakha, 2019[84] $)$ recent work on housing and resilience.
} 
A number of public policies affect the housing market and therefore wealth and its distribution. Such policies intend to repair market failures, pursue broader economic efficiency goals and promote affordable, quality housing for citizens. They include fiscal measures, macroprudential regulations on mortgage markets, the provision of social housing, regulations aimed at influencing rental markets as well as the quantity and quality of dwellings through land-use policies, urban planning and the enforcement of competition in related activities (e.g. construction, real estate). Some of these policies are designed to encourage homeownership as a vehicle for private wealth accumulation, whether stated explicitly or not as a policy objective. In particular, owner-occupied housing tends to be tax favoured in many OECD countries. ${ }^{3}$ Not surprisingly, reforms affecting housing wealth and its distribution tend to be unpopular. In this context, this paper attempts to analyse housing from a wealth distribution perspective by taking into account the political economy angle.

A key policy issue discussed in this paper is whether and how housing-related policies affect wealth distribution. Another important issue is whether housing-related policies raise potential trade-offs between equity and other policy objectives such as employment and productivity growth as well as macroeconomic resilience. This can be the case, for example, when housing-related policies reduce residential mobility and therefore labour market efficiency. To this end, the paper documents the facts about housing and wealth distribution. The analysis addresses several questions that are relevant from a policy perspective:

- How is homeownership and housing tenure distributed across the population along various socio-economic characteristics such as income, wealth and age? ${ }^{4}$ What is the weight of housing in households' balance sheets and how does this vary across socio-economic groups?

- What is the incidence of mortgage debt across households and how does this vary across socio-economic groups? What is the impact of mortgage debt on: i) access to homeownership and wealth accumulation; and ii) debt overburden and financial risks among vulnerable groups?

- Is housing a vehicle for wealth accumulation? Can it be a barrier to residential mobility?

- Is there a link between homeownership and wealth inequality? Between inequality in housing wealth and in total wealth?

The main findings are as follows:

- The contribution of housing to wealth inequality varies significantly across countries, yet the following facts stand out from the data:

- Wealth inequality is much higher and much more dispersed across countries than income inequality. On average across OECD countries, bottom $40 \%$ households receive around $20 \%$ of disposable income but only $3 \%$ of net wealth.

\footnotetext{
${ }^{3}$ Also the vast majority of OECD countries offer financial assistance to households to support the purchase of a home (Salvi del Pero et al., 2016[21]).

${ }^{4}$ Some of these issues are covered in the OECD Housing Affordability Database and in (Salvi del Pero et al., 2016 [21] $)$. Chapter 5 in (OECD, 2013 [12] $)$ focuses on housing for the old-age population.
} 
The higher level of wealth compared to income inequality partly reflects lifecycle effects.

- There is a strong negative cross-country association between homeownership and wealth inequality. Low homeownership countries exhibit high wealth inequality, even when income inequality is low.

- Housing tends to equalise the distribution of wealth from a static cross-country perspective. This is because housing is the most important and most widely-owned asset in household balance sheets, representing a much higher source of wealth among middle class households than at the top.

- The data does not lend strong support to the argument that housing acts as vehicle to encourage higher long-term savings.

- Access to mortgage markets allows credit constrained households a better chance of owning their own home, but it entails risks:

- Housing-related debt is the most important liability in households' portfolios, particularly for young homeowners and homeowners at the bottom of the distribution. OECD countries exhibit stark variation in the extent to which households hold mortgage debt, ranging from almost $50 \%$ in the Netherlands to less than $10 \%$ in Slovenia.

- Mortgage debt is both an opportunity and a risk. While it allows households, especially those with little initial assets, to accumulate wealth it could expose households, especially those at the bottom of the distribution, to economic and social vulnerabilities.

- Political economy considerations affect the design and implementation of housingrelated reforms and often make them unpopular:

- The median voter is a homeowner in many countries. Besides providing a shelter, for middle class households housing is the most important source of wealth accumulation. For low income households, it is often the only source of wealth transmission across generations through inheritance.

- One often stated challenge to housing reform is the fact that homeowners can be asset-rich and income-poor. Indeed, being a homeowner significantly reduces the risk of being asset poor, but it does not affect the risk of being income poor.

- Public policy tends to favour homeownership relative to renting, typically via the preferential tax treatment of owner-occupied housing relative to rented housing. Yet the case for departing from housing tenure neutrality in policy design is not clear, neither on efficiency nor on equity grounds.

- Informed by the stylised facts and existing evidence, this paper discusses preliminary policy implications of housing reform to promote inclusiveness and social mobility, to enhance efficiency in the allocation of labour and capital and to strengthen macroeconomic resilience:

- Making the overall tax system more progressive and efficient, for instance, by: i) shifting from income to progressive recurrent taxes on immovable property and on inheritance and gifts; and ii) phasing out the regressive features associated with the preferential tax treatment of owner-occupied housing such as mortgage interest deductibility. 
- Reducing household-level financial risks associated with mortgage debt through borrower-based prudential regulation such as loan-to-value or debt-toincome caps.

- Promoting residential mobility by: i) reducing housing transaction costs associated with taxation and the regulation of professional services; ii) curbing excessively strict rental regulations; and iii) reforming social housing programmes with a view to avoid lock-in effects and residential segregation and expanding welldesigned portable housing allowances. This requires complementary investments in public transportation and effective urban planning.

The structure of the rest of this paper is as follows. Section 1.2 briefly presents the framework and data for analysing housing from a wealth distribution perspective. Section 1.3 sets the scene and motivates the analysis with a number of stylised facts about housing and wealth inequality. Section 1.4 is the core of the paper and delivers evidence on homeownership and wealth accumulation along the asset and liability side, including by uncovering distributional patterns of over-indebtedness. Based on this new material, the policy discussion in Section 1.5 aims at identifying avenues for housing-related reforms that would have a traction on wealth distribution in the broader context of equity, efficiency and resilience objectives.

\subsection{Housing from a wealth perspective: concepts and data}

\subsubsection{The framework for micro statistics on wealth and housing wealth: a brief overview}

This section provides a short overview of the framework and basic concepts on household wealth, based on the international guidelines defined in (OECD, 2013 ${ }_{[2]}$ ) and applied in the datasets used in the analysis. It is important to stress that the empirical measurement of wealth is challenging, in absolute terms and relative to income. Statistical research is still ongoing in this area but the important progress achieved over the last decade allows a confident yet cautious analysis of wealth and housing in a cross-country perspective.

Definitions and accounting concepts. Household net wealth, following the OECD Guidelines for Micro Statistics on Household Wealth (OECD, 2013 ${ }_{[2]}$ ), is defined as the value of financial and non-financial assets net of the value of liabilities held by private households resident in the country. Unless otherwise stated, the analysis always measures wealth on a net basis: for example, the wealth quintiles refer to quintiles of the net wealth distribution. Assets consist of real assets including the value of the households' main residence (HMR) and value of other real estate property as well as financial assets (see (Balestra and Tonkin, 2018 ${ }_{[3]}$ ) and (HFCS, 2016 $6_{[4]}$ ). Household net housing wealth refers to the value of the HMR less that of HMR mortgage debt.

Unit of analysis. Wealth analysis based on micro data uses the household as unit of analysis and measures the wealth distribution across households rather than individuals, without taking account of differences in household size and composition. ${ }^{5}$ This follows international guidelines (OECD, 2013 $\left.{ }_{[2]}\right)$ and is standard practice in the literature since wealth may often be shared with others living in the same household. For analysing housing wealth, the use of the household as unit of analysis seems uncontroversial since the main home and any associated mortgage is usually jointly held by the partners in a couple.

\footnotetext{
${ }^{5}$ With the exception of asset-based poverty measures where the unit of analysis is the individual.
} 
Household reference person. The household reference person is a particular household member who is assumed to represent the household. This is needed for characterising the household according to characteristics such as education. The definition of the household reference person used in this paper follows the international standards of the Canberra Group (United Nations Economic Commision for Europe, 2011 $1_{[5]}$ ).

Non-sampling error and representativity of wealth surveys. Survey data are subject to both sampling and non-sampling errors. When sampling from a highly skewed distribution like that of wealth, most samples will underestimate inequality in the upper tail. For the majority of OECD countries, the data sources used in this paper address the top wealth issue by oversampling wealthy households, although the methods used for over-sampling vary depending on the information available (see Box 2.3 in (Balestra and Tonkin, 2018 ${ }_{[3]}$ ). For the purpose of analysing housing wealth, the issue of top wealth, underreporting and item non-response is less severe than for analysing other sources of wealth, notably financial wealth. Underreporting and non-response is most severe for financial assets whereas housing shows little bias (Davies, 2012[6]). Moreover, the focus of this paper is not on top wealth and top wealth inequalities.

The valuation of assets. The valuation of assets may have a major impact on measured wealth inequality. However, the literature shows that in a survey context, respondents' assessment of the current market value of their house is good, by contrast with the current market value of financial assets, insurance-related long-term savings and unincorporated business assets (Cowell et al., 2017 $\left[7_{[7]}\right.$ ). For the purpose of analysing housing wealth, the issue of asset valuation is unlikely to entail significant measurement error.

Pensions. Public and occupational pension plans are not included in financial assets and thus neither in household net wealth. International guidelines on micro statistics on household wealth require to maintain consistency with the definition of financial assets in the system of national accounts (SNA), which reflects the view that reliable estimates of pension entitlement in social security schemes may not be readily available. It can be argued that, even where estimates of pension entitlements in social security schemes can be derived for individual households, they would be of limited usefulness in cases where a government can change the basis on which the entitlements are determined in order to keep them within the bounds of what is feasible from a budget perspective. Estimating private wealth from public pensions is well beyond the scope of this paper and any such exercise would in any case have to rely on questionable assumptions. ${ }^{6}$

\subsubsection{Data sources}

This section provides a short overview of the data sources used throughout the paper for analysing housing and wealth distribution (see ECO/CPE/WP1(2019)1/ANN2). The first source is the OECD Wealth Distribution Database (WDD) (Box 1). It has been recently launched to provide harmonised high-quality information on household wealth across OECD countries, based on estimates from household surveys and administrative data. This source has not yet been exploited for housing analysis and is a valuable starting point to deliver a number of stylised facts about housing and wealth distribution.

\footnotetext{
${ }^{6}$ See (Cowell et al., 2017 $\left.{ }_{[7]}\right)$ for a discussion and an estimation of the effect of including public pension wealth on the level and distribution of private wealth. See also (Balestra and Tonkin, 2018[3]).
} 
The use of the semi-aggregated data from WDD is complemented with micro data. ${ }^{7}$ One main source for this paper is the Household Finance and Consumption Survey (HFCS) database from the European Central Bank. It provides individual household data collected in a harmonised way in euro area countries as well as Hungary and Poland. Although the survey does not refer to the same time period in all countries, the most common reference period for the latest available data is 2014. The main aim of the HFCS is to gather microlevel structural information on euro area households' assets and liabilities e.g. real assets and their financing, liabilities/credit constraints, private businesses, financial assets, intergenerational transfers and gifts, and consumption and saving. The survey also collects other distributional-relevant information in particular gross income, labour market status, education and demographic characteristics. The data allow to analyse the joint distribution of housing wealth, net wealth and income, while taking into account socio-demographic effects. The HFCS-based microdata analysis is complemented with the Luxembourg Wealth Study (LWS) for non-Euro area countries. The LWS is a widely-used semiharmonised dataset providing individual data on household wealth, but through a remote access procedure. The data allow to cover a number of additional OECD countries: Australia (2014), Canada (2012), Norway (2013), ${ }^{8}$ the United Kingdom (2013) and the United States (2016).

\section{Box 1. The OECD wealth distribution database}

The OECD relies on a dedicated statistical database, the OECD wealth distribution database (WDD), to benchmark and monitor wealth inequality across countries. This database is based on national sources (household surveys and administrative records) and on common definitions, classifications and data-treatments. Estimates referring to the most recent year (around 2015) are currently available for 28 OECD countries, while estimates referring to more than one year are available for 19 countries. All the indicators available through this database are based on the concept of "household net wealth" as defined in the OECD Guidelines for Micro Statistics on Household Wealth (OECD, 2013 ${ }_{[2]}$ ), i.e. the value of financial and non-financial assets net of the value of liabilities held by private households resident in the country, with no adjustment made to reflect differences in household size. Assets held in the form of "pension schemes related to employment" are reported as a separate category for some countries.

The method of data collection used for the OECD WDD aims to maximise internationally comparability as well as inter-temporal consistency of data. This is achieved by a common set of protocols and statistical conventions (e.g. on wealth concepts and components) to derive comparable estimates. For 11 countries, estimates are obtained through a questionnaire completed by contact points in national statistical offices (and central banks) that regularly collect micro-level information on household wealth; among these, estimates for Australia, Canada, Chile, Japan, Korea, New Zealand, the United Kingdom and the United States are based on household surveys, while those for Denmark, the Netherlands and Norway are based on tax and administrative records. For 17 countries (i.e. those participating in the Household Finance and Consumption Survey (HFCS) (except the

\footnotetext{
${ }^{7}$ For a number of countries, results from the microdata analysis are not directly comparable with those obtained from the WDD, because they either refer to a different data source (i.e. the Netherlands) or to previous years (i.e. Australia, Canada, Norway and the United Kingdom).

${ }^{8}$ Norway is included whenever possible but the data coverage of key variables is comparatively poor.
} 
Netherlands), estimates are computed by the OECD based on the data provided by the European Central Bank.

Despite efforts made to ensure common treatments and classifications across countries, the measures included in the OECD WDD are affected by differences that may limit their comparability. The most important are: i) differences across countries in the year when data are collected (ranging between 2012 and 2016, for the most recent year); ii) differences in the degree of oversampling of rich households across countries, which may affect comparisons of both levels and concentrations of household wealth; iii) differences in the income concept recorded: while most wealth surveys provide information on household disposable income, countries covered by HFCS rely on the concept of gross income (with the exception of Italy and Finland, for which information on disposable income is also available), which limits the cross-country comparability of estimates of the joint distribution of income and wealth; and iv) differences in institutional arrangements governing pension systems, since financial assets exclude pension wealth from public and occupational pensions, in line with current international Guidelines for Micro Statistics on Household Wealth.

For more information, see (Balestra and Tonkin, 2018 ${ }_{[3]}$ ) and http://www.oecd.org/sdd/OECD-wealth-distribution-database-metadata.pdf

\subsection{Stylized facts on housing and wealth inequality}

\subsubsection{Prologue and motivation: wealth relative to income inequality ${ }^{9}$}

Wealth inequality is much higher and much more dispersed across countries than income inequality (Figure 1). The higher level of wealth relative to income inequality in part reflects that wealth accumulates over the lifecycle (see section 1.4.1) which implies that, all else equal, in any given point in time income inequality is expected to be lower than wealth inequality. The strength of the cross-country correlation between the two measures depends on the inequality measure used. It is relatively strong when the emphasis is on the middle of the distribution and, to a lesser extent, on the top of the distribution. By contrast, wealth and income inequality are uncorrelated when the emphasis is on the bottom of the distribution. The lack of data on occupational pensions (as discussed in Box 1) likely implies an overestimation of wealth inequality in countries where such pensions are widespread such as Denmark and the Netherlands, main patterns can be summarised as follows:

- The cross-country rank correlation between wealth and income inequality is the highest when the focus is on the middle of distribution. On average across OECD countries, the share of income going to the middle $60 \%$ of the distribution ${ }^{10}$ is around $54 \%$ of disposable income, while in the case of net wealth it is $33 \%$. The cross-country dispersion in net wealth is higher than in income (Figure 1, Panel A).

- Wealth is much more concentrated at the top than income. On average across OECD countries, top $10 \%$ shares double when moving from income to wealth and

\footnotetext{
${ }^{9}$ A comprehensive analysis of wealth inequality, including a relevant discussion on the top of the distribution, is not the scope of the current paper and is covered in recent SDD work (Balestra and Tonkin, 2018 $\left.8_{[3]}\right)$.

${ }^{10}$ The middle $60 \%$ of the distribution is one standard measure of the middle class. See (Causa et al., 2014 ${ }_{[51]}$ ) and (Atkinson and Brandolini, 2011 ${ }_{[53]}$ ) for a discussion on defining and measuring the middle class.
} 
the cross-country dispersion rises. Top income shares range from less than $20 \%$ to around $30 \%$, while top wealth shares range from $35 \%$ to almost $80 \%$. The association between wealth and income inequality at the top is not very tight, as can be seen by comparing the United States and the United Kingdom (Figure 1, Panel B).

Figure 1. Wealth inequality is much higher as well as much more dispersed across countries than income inequality

Panel A. Middle $60 \%$ share

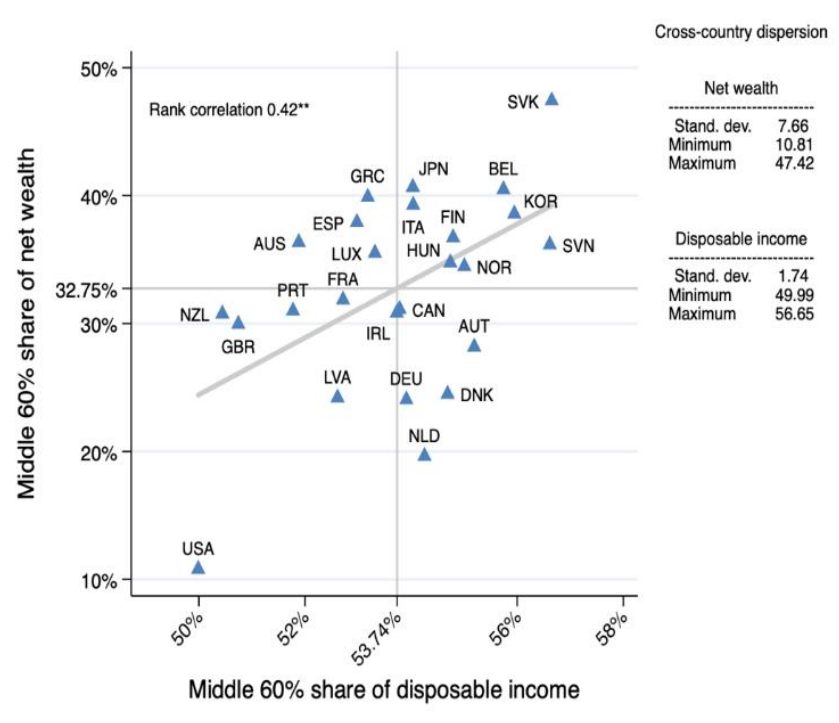

Panel C. Top $10 \%$ share

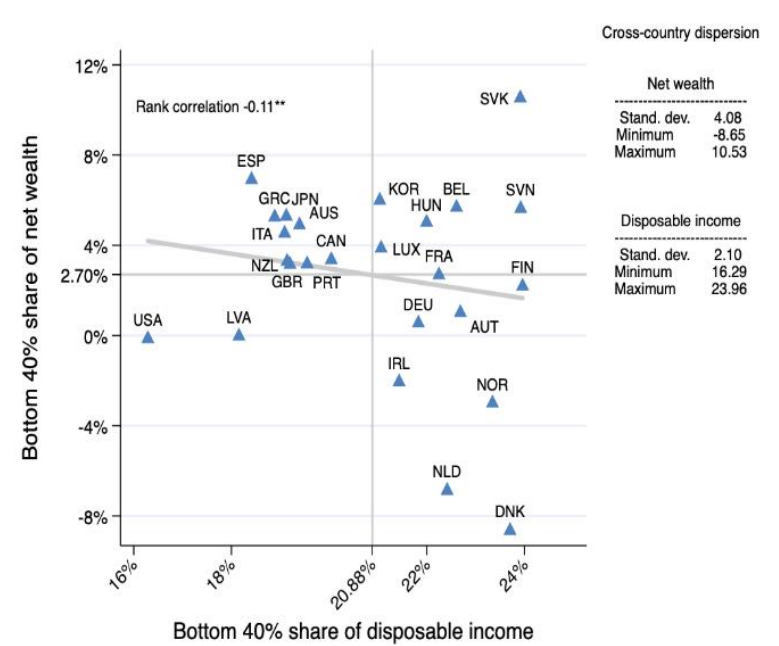

Panel B. Bottom $40 \%$ share

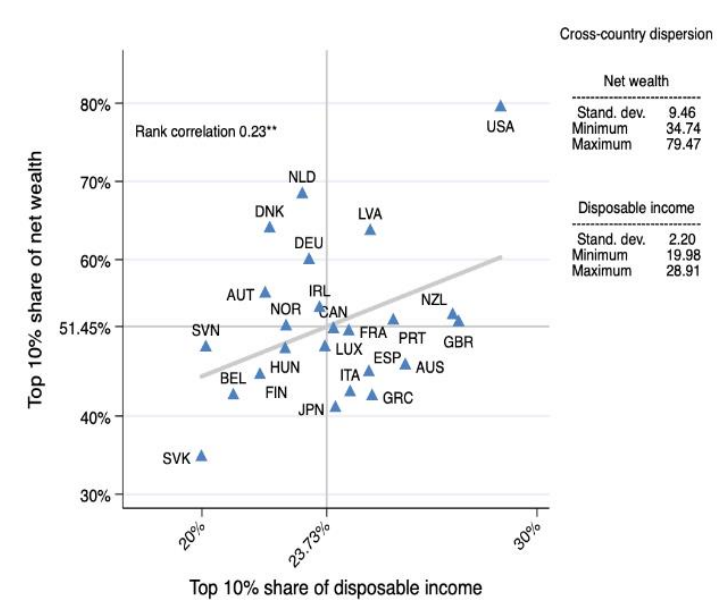

Panel D Bottom $40 \%$ shares and income redistribution

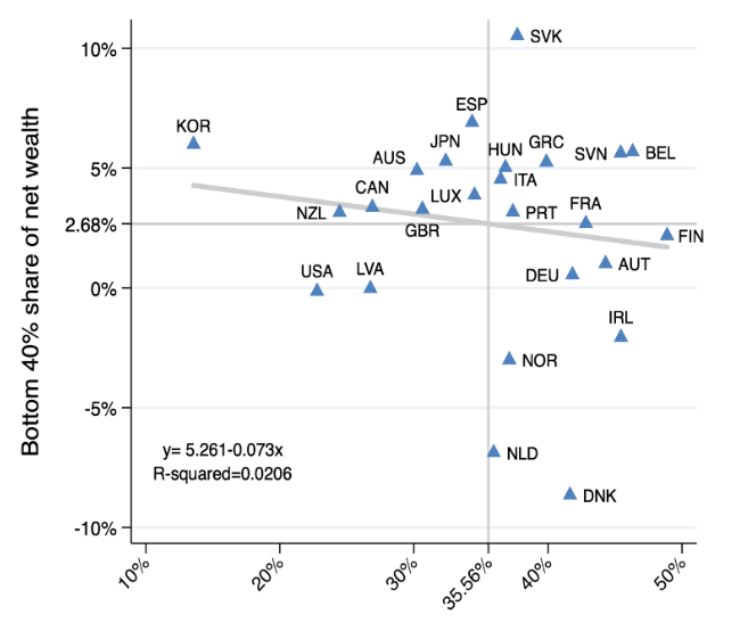

Income redistribution (\% inequality reduction by taxes and transfers)

Source: OECD Wealth Distribution Database (oe.cd/wealth), OECD Income Distribution database (https://stats.oecd.org/Index.aspx?DatasetCode=IDD).

Note: Income redistribution is defined by the degree of inequality reduction achieved by taxes and transfers (Causa and Hermansen, 2017 $[8]$ ). This is measured by the difference between the Gini indexes in market and in disposable income, normalised by the Gini index in market income. Incomes are equivalised. 
- The difference in countries' relative positions on income and wealth inequality is most pronounced at the bottom of the distribution (Figure 1, Panel C). On average across OECD countries, bottom $40 \%$ households receive around $20 \%$ of disposable income but only $3 \%$ of net wealth. The rank correlation between the two inequalities is slightly negative. One argument put forward to explain this pattern is that public insurance through the welfare state and redistribution crowds out private insurance through precautionary savings, especially among the poor. ${ }^{11}$ This is consistent with the fact that some low inequality/high redistribution countries exhibit among the highest levels of wealth inequality at the bottom. However, the correlation between income redistribution and wealth inequality at the bottom is tenuous (Figure 1, Panel D).

\subsubsection{Homeownership and wealth inequality}

As a starting point to analyse housing and wealth inequality, simple bivariate correlations suggest a strong negative association between homeownership and wealth inequality (Figure 2). High (low) homeownership countries tend to display low (high) wealth inequality. The focus on middle $60 \%$ and bottom $40 \%$ wealth shares indicates some heterogeneity among low-homeownership countries (Figure 2, Panels A and B). For instance, given similar levels of homeownership, Austria and Germany exhibit substantially higher bottom $40 \%$ wealth shares than Denmark and the Netherlands. The negative association between homeownership and wealth inequality persists at the top of the distribution, but again with some dispersion across countries (Figure 2, Panel C). In this case, the position of the United States, and, though to a lesser extent, the Netherlands stands out. For a similar level of homeownership than that observed in France, the share of wealth accruing to the top $10 \%$ is around $80 \%$ in the United States and $70 \%$ in the Netherlands while it is around $50 \%$ in France.

11 (Pham-Dao, 2016 $6_{[70]}$ ) constructs a life-cycle model with heterogeneous agents and incomplete markets and calibrates it to euro area differences in net earnings, unemployment dynamics and welfare policies. Welfare policies are found to account for $58 \%$ of the differences in net wealth Gini among the bottom $95 \%$ of the wealth distribution. 
Figure 2. High-homeownership countries tend to exhibit low wealth inequality

share

Panel A: Middle $60 \%$ share

Panel B: Bottom 40\%
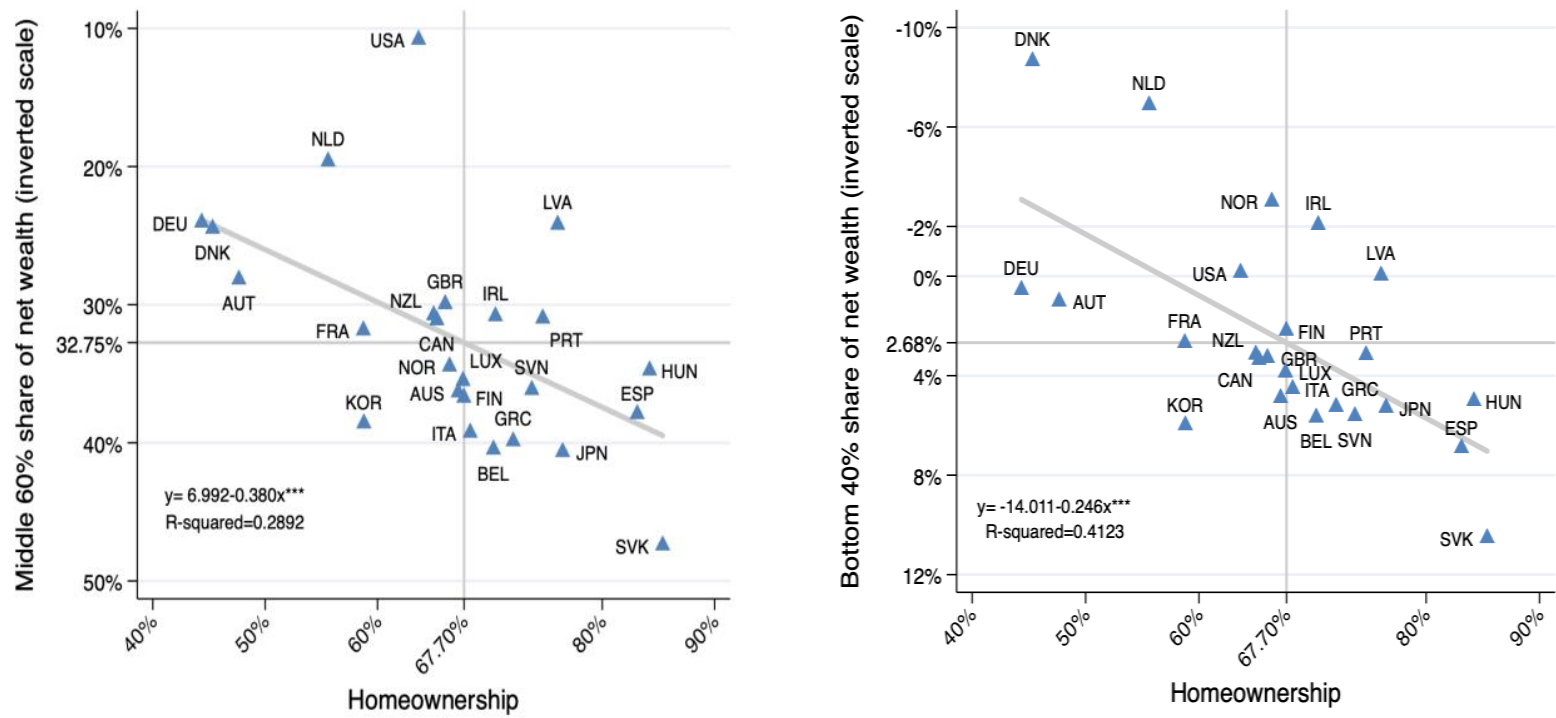

Panel C: Top $10 \%$ share

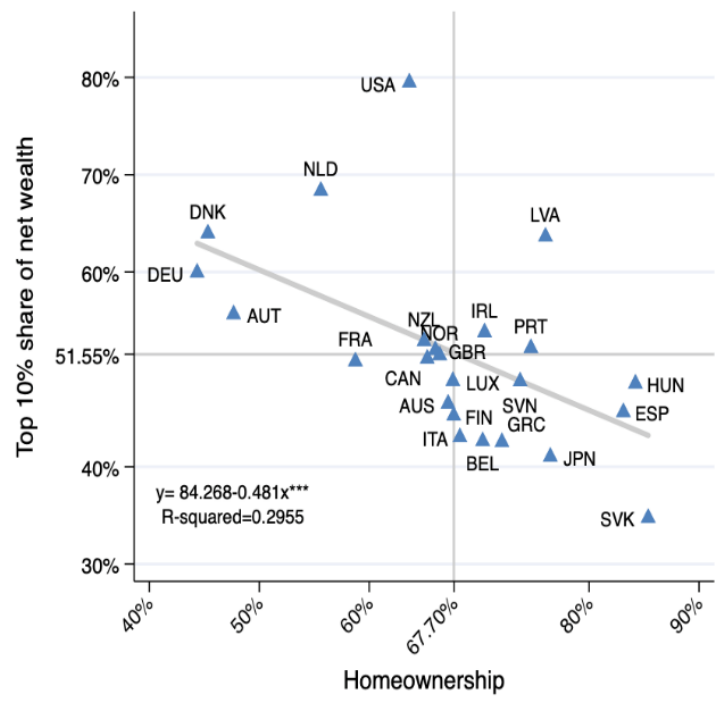

Source: OECD Wealth Distribution Database (oe.cd/wealth)

\subsubsection{Inequality in net wealth and in net housing wealth}

1. Inequality in net housing wealth and in net wealth are highly correlated across countries (Figure 3). Key insights are:

- By and large, inequality in net wealth is higher than in net housing wealth. On average across OECD countries, the middle $60 \%$ share of net wealth is around $33 \%$ while that of net housing wealth is around $46 \%$ (Figure 3, Panel A). 
- The gap between inequality in net wealth and in net housing wealth is highest at the top of the distribution. Focusing on the bottom of the distribution, the two inequality metrics almost overlap (Figure 3, Panel B). Shifting to the top of the distribution increases the difference between the two inequalities (Figure 3, Panel C). The gap between top $10 \%$ shares of total and housing wealth is larger than that of middle $60 \%$ and bottom $40 \%$ shares. This is likely to reflect that non-housing sources of wealth, such as business and financial wealth, become more important at the top of the distribution.

Given the strong association between inequality in net housing wealth and in net wealth, Box 2 sheds light on the "contribution" of housing to total wealth inequality. The results suggest that housing equalises the wealth distribution in a cross-country perspective: "removing" housing from net wealth implies a significant increase in measured wealth inequality, around one quarter on average across the countries for which the calculation can be done. The equalising power of housing is stronger in high-homeownership countries such as Eastern European countries and Spain and weaker in low-homeownership countries such as Austria and Germany.

One question is whether the equalising power of housing persists in a dynamic perspective. This question is tentatively addressed in the Annex by looking at developments in homeownership, house prices and wealth inequality in the sub-sample of countries for which comparable time-series are available in the OECD Wealth distribution database. The analysis does not lead to strong conclusions because the changes refer to short time spans over recent periods. The data suggest that that in countries where homeownership is widespread, bottom households tend to be particularly sensitive to changes in house prices. 
Figure 3. Net wealth inequality and net housing wealth inequality are highly correlated across countries

Inequality in net wealth and in net housing wealth

Panel A: Middle 60\% share

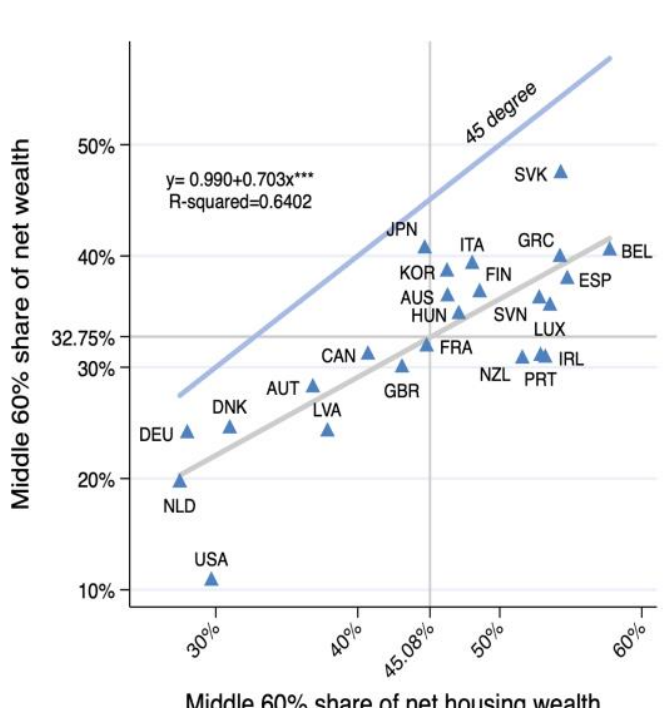

Middle $60 \%$ share of net housing wealth
Panel B: Bottom 40\% share

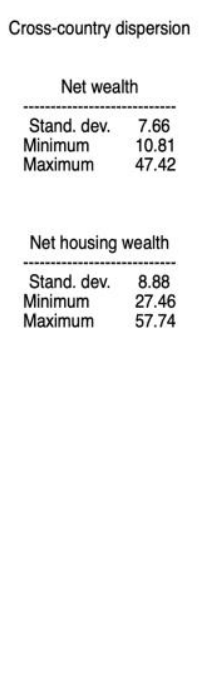

Panel C: Top 10\% share
Cross-country dispersion

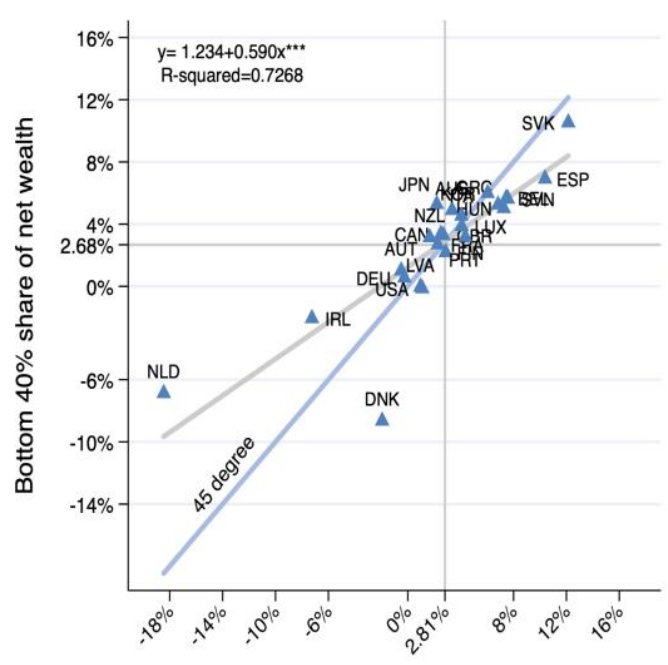

Bottom $40 \%$ share of net housing wealth

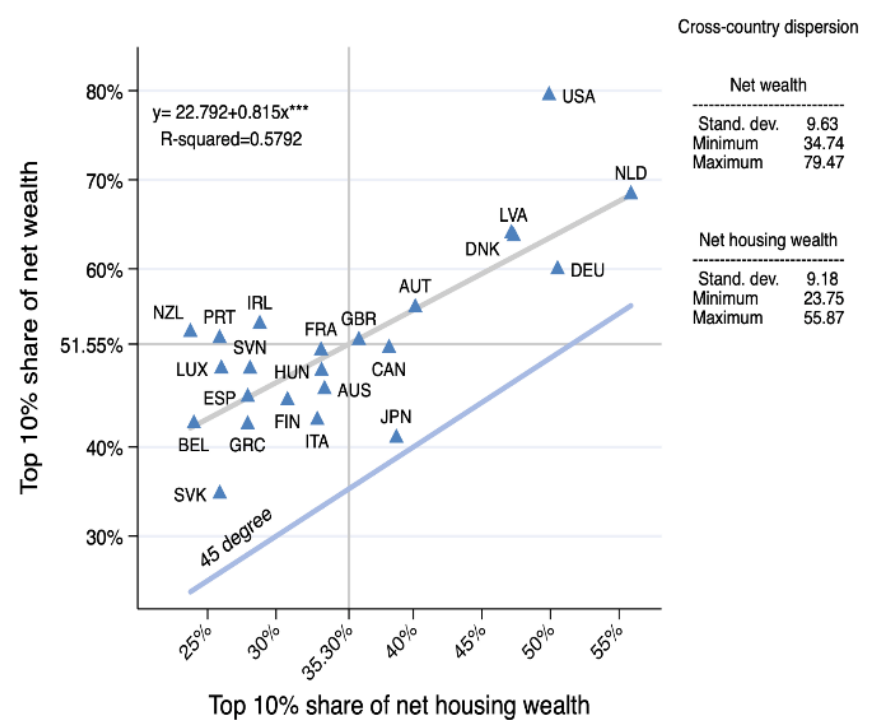

Note: Households are ranked by net wealth.

Source: OECD Wealth Distribution Database (oe.cd/wealth) 


\section{Box 2. The contribution of housing to wealth inequality: a simple illustrative exercise}

One way to measure the contribution of housing to wealth inequality is to compare wealth inequality with and without housing (see (Azpitarte, 2010[9])). This requires using micro data, subtracting net housing wealth from net total wealth for each household, then computing on this basis inequality of net wealth "without housing" measured by the Gini index and comparing this to the Gini index of net wealth. The Gini index ranges between 0 in the case of perfect equality and 1 in the case of perfect inequality. It must be recognised that in the case of net wealth this index is more difficult to interpret than in the case of income because it can in principle be higher than 1 due to the presence of 0 and negative values. That said, contrary to many other inequality indexes, the Gini can be computed in the presence of negative values, which is why it is standard in the wealth literature even though its interpretation is less straightforward than in the case of income. The interpretably issue is however not so relevant for the purpose of assessing wealth inequality with and without housing because both metrics refer to wealth.

This exercise suggests that housing equalises the wealth distribution in a cross-country perspective (Figure 4). "Removing" housing from net wealth implies a significant increase in measured wealth inequality. On average across OECD countries, measured net wealth inequality increases by around one quarter: from 0.66 (net wealth) to around 0.82 (net wealth "without housing").

Figure 4. Housing tends to equalise the distribution of wealth in a cross-country perspective

Housing and wealth inequality: removing housing from overall net wealth, Gini index

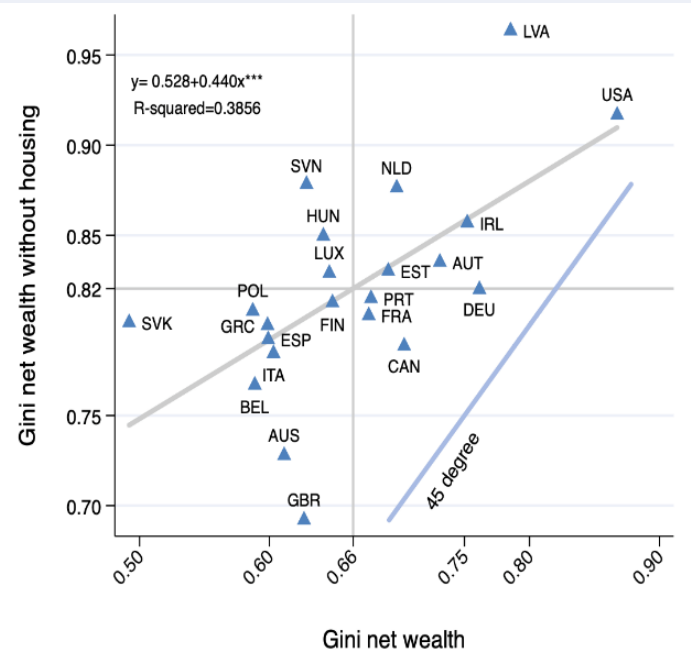

Source: Authors' calculations based on HFCS and LWS data.

One limitation of this exercise is that it is purely an accounting one as it does not address the counterfactual of a "no-housing" scenario, that is, what the composition and distribution of households' wealth would be when investing in housing wealth would not be an option. In addition, the approach is static since the comparison is across countries at a given point in time. So, the analysis gives an idea of the contribution of housing to wealth inequality in a cross-section of OECD countries, but it tells nothing of the contribution of housing to changes in wealth inequality within countries. The latter question cannot be addressed with the available cross-country data. 


\subsection{Stylized facts on homeownership, housing assets, housing liabilities and wealth accumulation}

\subsubsection{Homeownership, housing wealth and the lifecycle}

\section{Housing tenure and housing wealth across the distribution}

OECD countries exhibit great variation in the housing tenure mix, i.e. in homeownership rates and in the relative proportion between outright owners and owners with mortgage (Figure 5). ${ }^{12}$ Homeownership rates vary from around $80 \%$ in the Slovak Republic, Hungary and Spain to around $40 \%$ in Germany, Denmark and Austria, with an average at around $60 \%$. Part of cross-country differences reflect historical legacies, in particular high homeownership rates in Eastern European countries as a result of mass privatisation at submarket prices to sitting tenants (e.g (Huber and Schmidt, 2016 $\left.{ }_{[10]}\right)$ ). A number of studies have suggested that cross-country differences in aggregate homeownership rates are due to differences in policies and institutions that affect housing demand and supply such as e.g. regulations of mortgage markets, of rental markets, the provision of social housing, taxation and land-use policies (e.g. (Andrews, Caldera Sánchez and Johansson, 2011 $\left.{ }_{[11]}\right)$ ). Some of these policies are also likely to affect the mix between outright owners and owners with mortgage. For example, the Netherlands and France exhibit similar homeownership rates, but the proportion of owners with a mortgage is much higher in the Netherlands than it is in France (Figure 5).

Figure 5. OECD countries exhibit great variation in the housing tenure mix

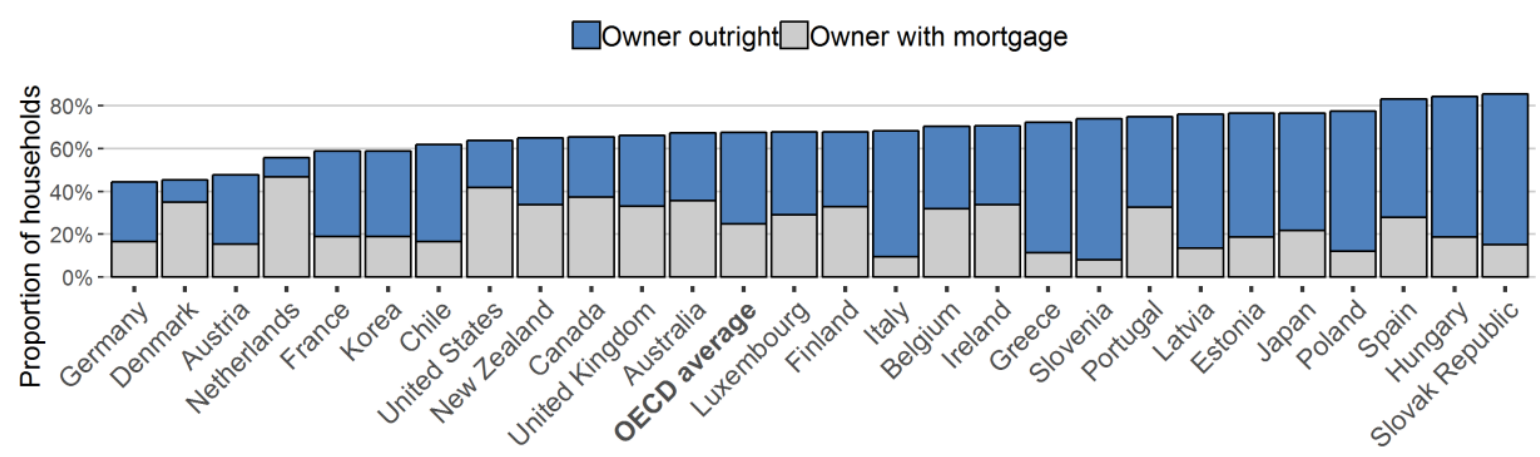

Source: OECD Wealth Distribution Database (oe.cd/wealth)

Cross-country differences in the housing tenure mix partly reflect differences in households' socio-demographic characteristics notably the structure of households in terms of age and size.$^{13}$ In the vast majority of countries, households composed of retirement age members and larger households are more likely to be owners while households composed of younger members and single person households are more likely to be renters (Figure 6). Among owners, households composed of retirement age members are more likely to be outright owners relative to younger households. One implication is that part of observed

12 Homeownership rates from the WDD may differ from those based on the OECD Housing Affordability Database as the latter relies on the national data sources.

${ }^{13}$ For a comprehensive analysis of the impact of households' structure on differences in households' holding of various assets, hence housing, alongside some wealth distribution implications, see (Fessler, Lindner and Segalla, 2014 $[82]$ ). 
cross-country differences in the tenure mix are not amendable to policy intervention. This implication should be nuanced: i) OECD countries exhibit large differences in housing tenure mix within socio-demographic groups ${ }^{14}$ especially among young households which is likely to partly reflect differences in policy settings, in particular access to mortgage finance (see next section); and ii) evidence suggests that household formation decisions can be influenced by housing-related policies on top of economic e.g. labour market conditions. 15

Figure 6. Households' characteristics in terms of age and size are major drivers of housing tenure

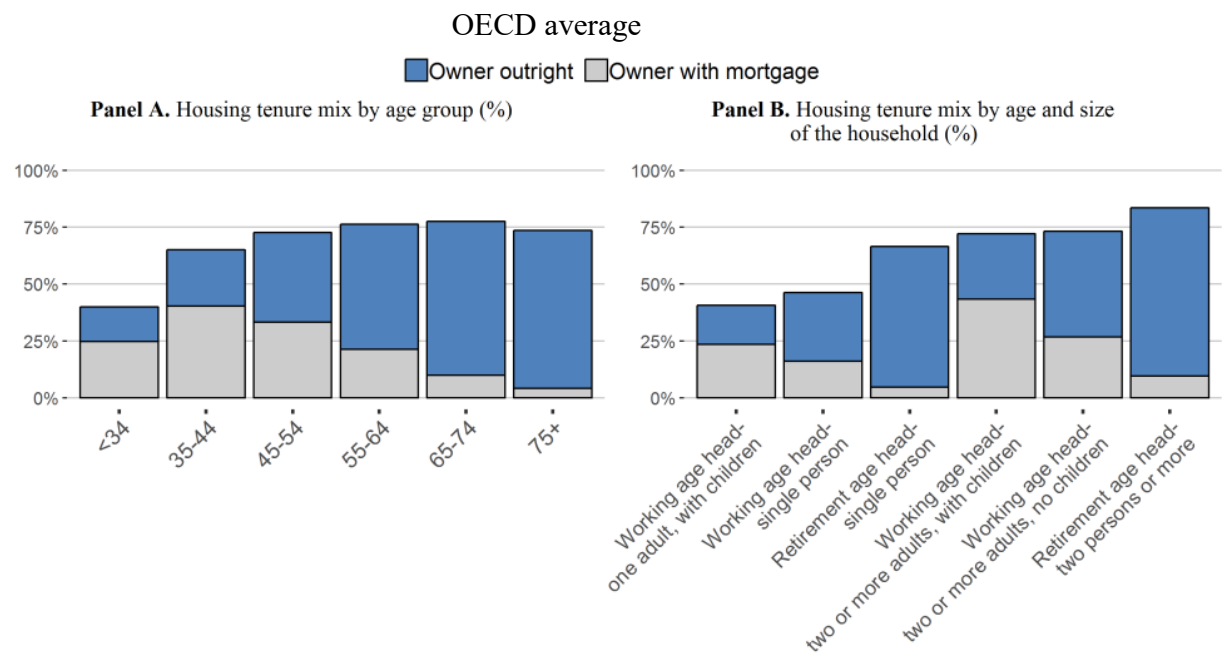

Source: OECD Wealth Distribution Database (oe.cd/wealth).

Patters in homeownership rates across the income and wealth distribution deliver new insights on the distributional implications of housing and the potential role of public policies (Figure 7). Starting with the income distribution, the data show that high homeownership countries generally exhibit a low difference in homeownership between low and high income households, while the reverse tends to apply to low homeownership countries (Figure 7, Panel A). By contrast, there is no systematic cross-country link between overall homeownership rates and the difference in homeownership between low and high wealth households (Figure 7, Panel B). For instance, the largest differences in homeownership between households at the top and bottom of the wealth distribution are in high homeownership countries, Italy and Poland, while the smallest ones are in low homeownership countries, the Netherlands and Denmark. Cross-country differences in homeownership among households at the bottom of the net wealth distribution may partly reflect differences in institutional settings, in particular in terms mortgage market regulations.

Key stylised facts of the role of housing in households' assets composition are (Figure 8):

- Housing is the highest ranked asset in households' portfolios (Figure 8, Panel A) as it represents on average around half of total assets, ranging from around $70 \%$ in the Slovak Republic to around 25\% in Germany. The weight of secondary houses

15 For example, empirical evidence suggest that lack of access to credit delays the age at which individuals leave the family house to become homebuyers, with Italy being an example (Chiuri and Jappelli, $2003_{[50]}$ ). 
("other real estate") tends to be relatively high, for instance higher than that of financial assets in a number of countries, further highlighting the importance of immovable property for household wealth.

- Housing is the chief asset of the "middle class" (Figure 8, Panel B). The share of housing in total assets of the "middle class" (proxied by households in the middle three quintiles of the income or wealth distribution) is larger than $60 \%$ in the majority of OECD countries.

- Housing is a relatively less important asset at the very top of the distribution (Figure 8, Panel C).${ }^{16}$ On average across the OECD, it represents around one quarter of total assets among households at the top $1 \%$ of the net wealth distribution. Average figures mask substantive cross-country heterogeneity, part of which may reflect policy factors, e.g. tax incentives to invest in housing relative to other assets and their effects on developments in house prices relative to prices of other assets.

- Cross-country differences in the importance of housing for household wealth are most pronounced at the bottom of the distribution (Figure 8 , Panel D). While the share of housing in total assets among bottom income households is relatively high in high-ownership countries and relatively low in low-ownership countries, this stylised fact does not hold among households at the bottom of the net wealth distribution.

\footnotetext{
${ }^{16}$ The reported share of housing in total assets at the very top of the wealth distribution should be taken with care due to small sample size in some countries. Also, some of the cross-country difference in top wealth asset composition could be driven by variation in oversampling rates and by the use of different data sources (administrative as opposed household surveys).
} 
Figure 7. High homeownership countries exhibit low income spread but not necessarily low wealth spread

Panel A. Homeownership across the income distribution

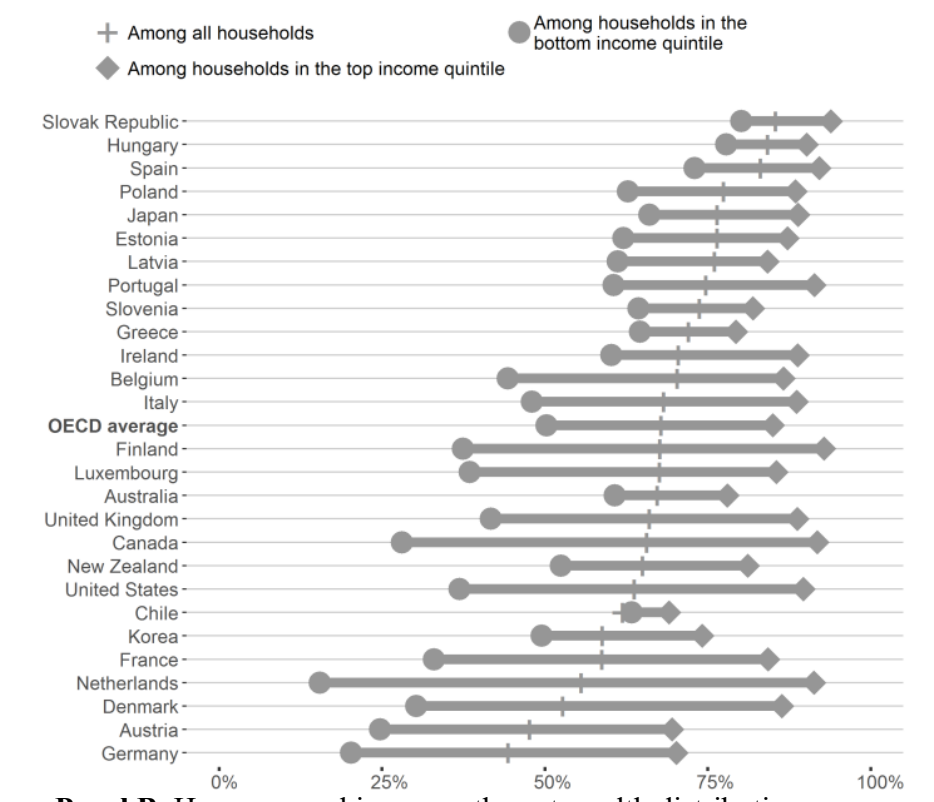

Panel B. Homeownership across the net wealth distribution

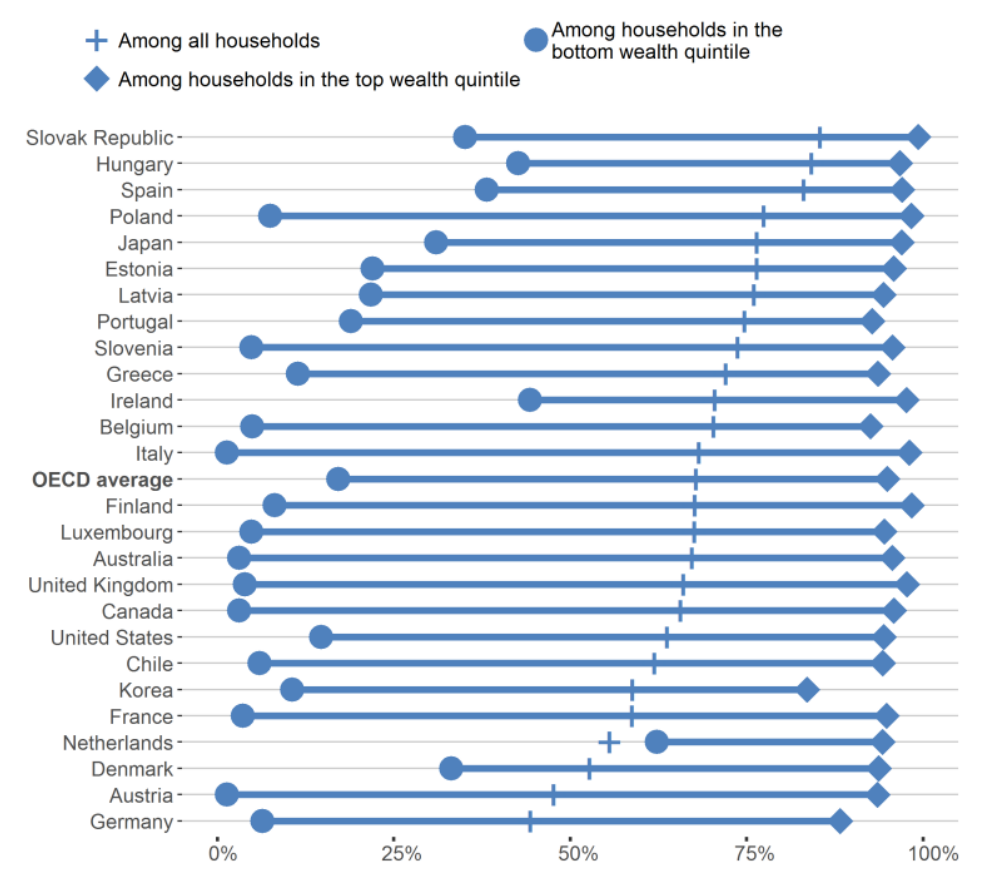

Source: OECD Wealth Distribution Database (oe.cd/wealth). Household Economic Survey database for New Zealand. Note: Homeownership among households in the bottom net wealth quintile can be higher than among all households (e.g. in the case of the Netherlands). This is the result of composition effects in the bottom net wealth quintile. Net wealth is equal to total assets minus total liabilities, the bottom net wealth quintile can thus be composed either of low asset households, or of highly-leveraged households. Countries that experienced sharp declines in house prices in the period before 2014 (such as Ireland and the Netherlands) display high homeownership in the bottom net wealth quintile because many homeowners experienced shrinking net wealth and even negative equity due to high leverage in combination with asset depreciation. This shifted the composition of the bottom net wealth quintile towards more homeowners with a mortgage. 
Figure 8. Housing is the chief asset of the middle class

Panel A. Asset decomposition of households' portfolio
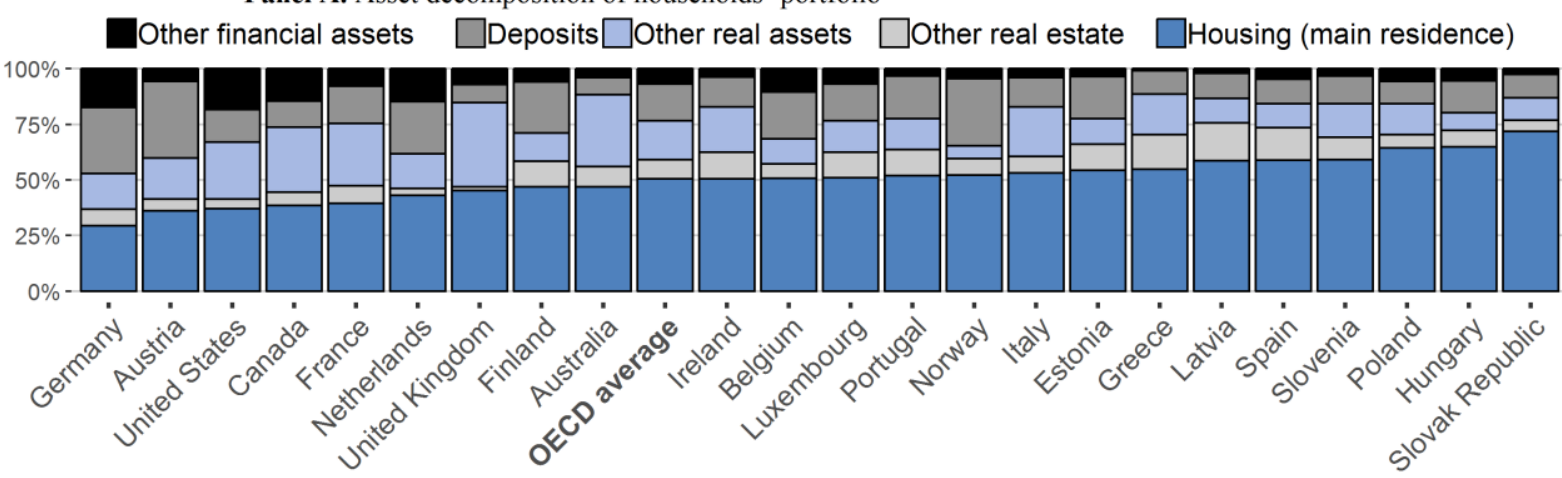

Panel B. Housing as a share of total assets among households in the middle of the distribution

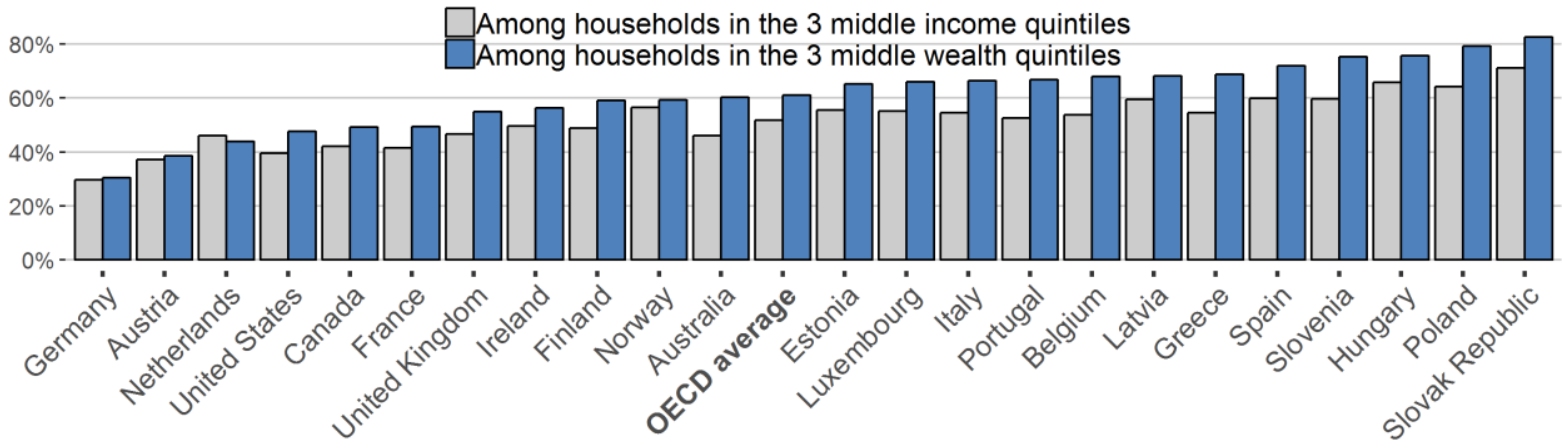

Panel C. Housing as a share of total assets among households at the top of the distribution

$\square$ Among households in the top quintile of the wealth distribution

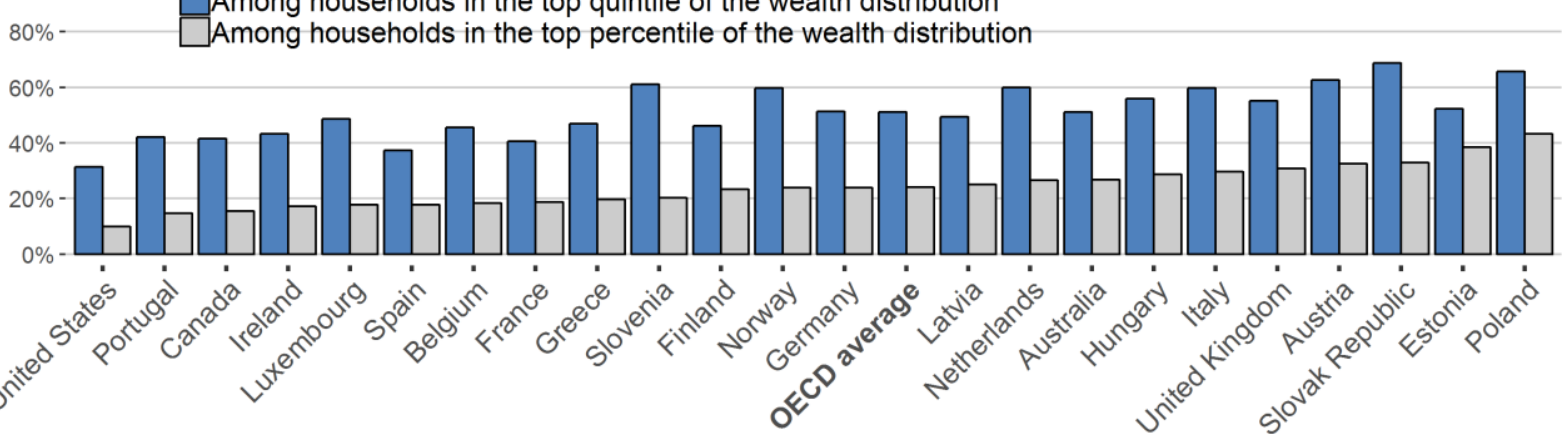

Panel D. Housing as a share of total assets among households at the bottom of the distribution

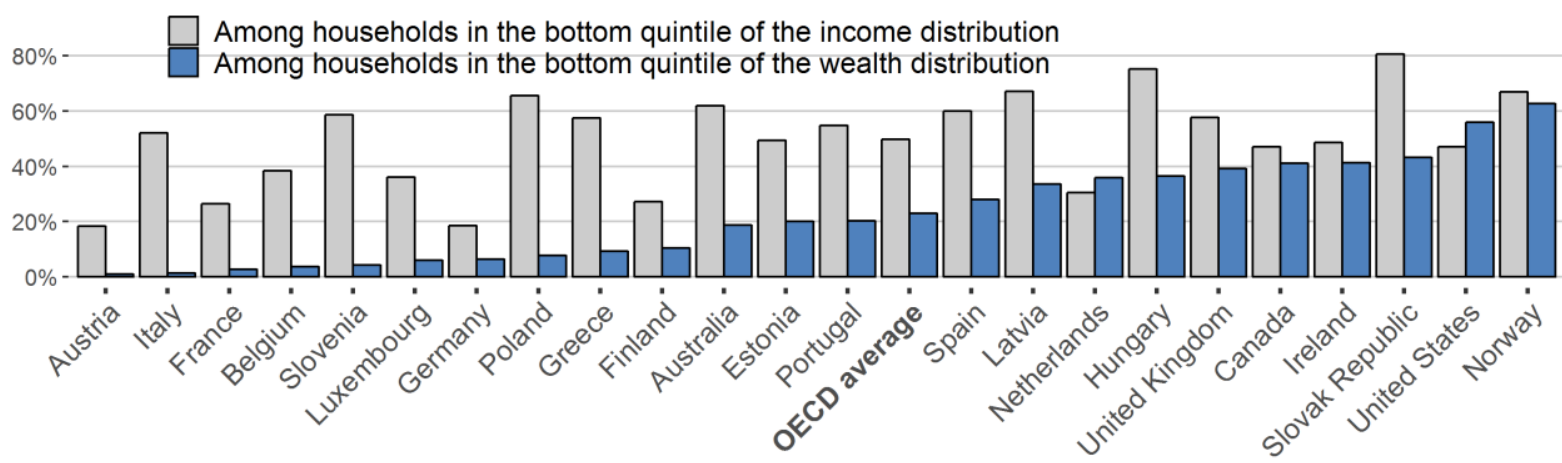

Source: Data from HFCS and LWS. 


\section{Housing wealth and the lifecycle}

Wealth accumulates over the lifecycle and the evidence suggests that this process is strongly associated with housing (Figure 9). On average across OECD countries, housing wealth and overall wealth exhibit a hump-shaped curve across the lifecycle. So does income but with major differences: i) wealth picks-up later in the lifecycle than income; and ii) wealth accumulation is much steeper than income accumulation, but wealth decumulation is much flatter than income. As people age, their income decreases much more than their wealth, especially than their housing wealth. Towards the end of their lives, people tend to have not consumed their housing wealth, which remains relatively close to its peak level.

This broad picture conveyed by the OECD average masks large cross-country differences in lifecycle effects. For instance in the United States net housing wealth is not hump-shaped over the lifecycle as it continues rising with age, while income declines steeply from age group 55-64. This analysis should be taken with caution as it is based on wealth and income comparisons of different age groups at a given point in time, not on longitudinal data following individuals over time. As a result, differences across age groups may reflect cohort effects as opposed to lifecycle effects, for example insofar as given cohort has benefitted relatively more from rising house prices.

Figure 9. Housing wealth tends to be hump-shaped across the lifecycle, but with large cross-country differences

Net wealth, net housing wealth and income across the lifecycle, OECD average and selected countries

- Gross income $=$ Net housing wealth - Net wealth

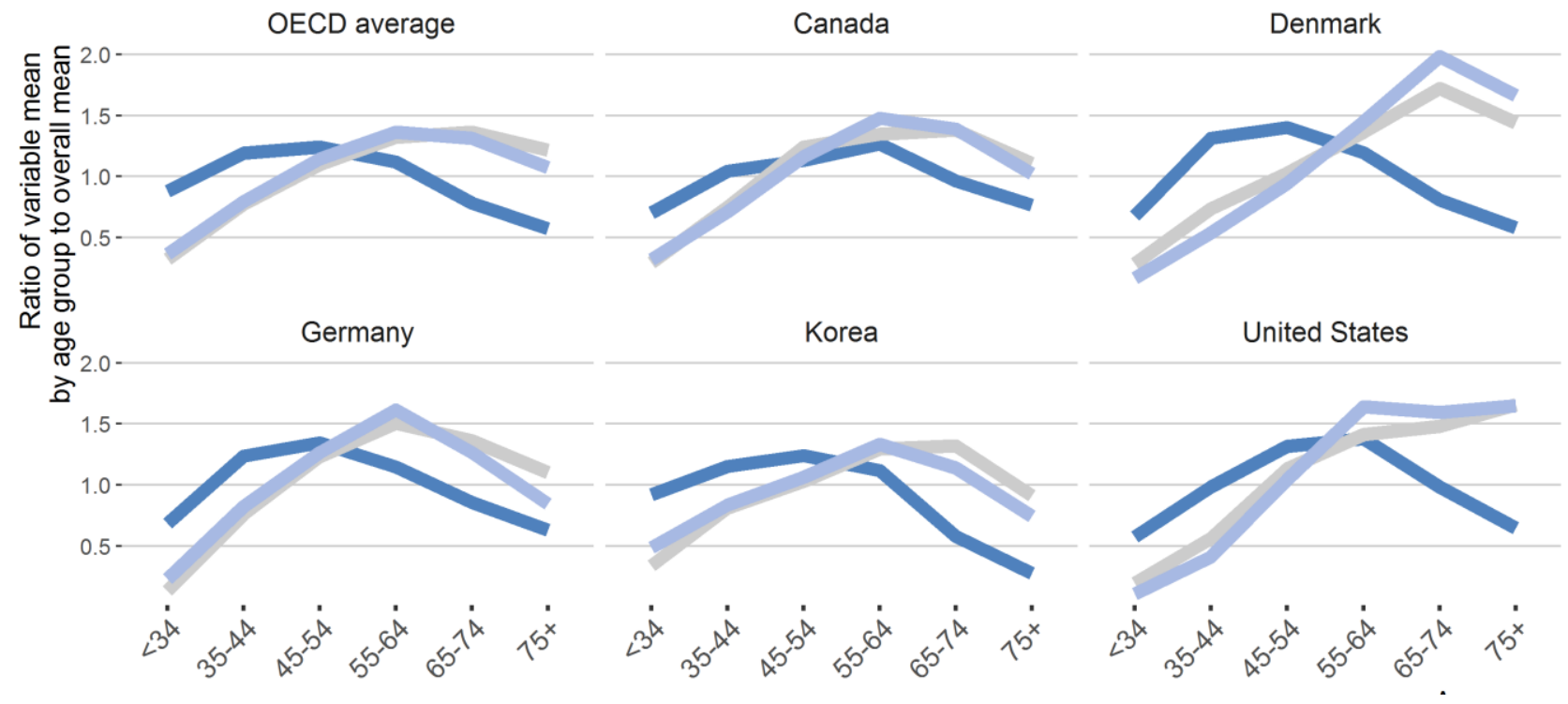

Note: How to read this figure: in Canada, mean net wealth among the 35-44 age group is 0.7 times that of overall population while mean net wealth among the 55-64 age group 1.5 times that of overall population. Mean net wealth among the $75+$ age group is close to being equal to that of the overall population.

Source: OECD Wealth Distribution Database (oe.cd/wealth).

Cross-country comparisons of housing wealth across the lifecycle raise relevant policy questions, for instance on the link between housing and living standards in old-age. One question is how the generosity of the welfare state through the pension system may interact with homeownership: do people invest in housing as a form of social protection in countries 
where public pension generosity is relatively low? Box 3 tentatively investigates the link between homeownership among the elderly and various metrics of public pension generosity. The conclusion is that there is no clear nexus between housing and pensions, in line with the tenuous link found between income redistribution and wealth inequality. The inference is that other factors are likely more decisive in homeownership than retirement considerations and what people can expect to receive from pension systems. It also points to the difficulty of making housing wealth an important factor in retirement income policy.

\section{Box 3. Homeownership, the welfare state and public pensions}

A number of studies have argued that high levels of owner-occupation reduce the need for generous pensions. Accordingly, in less generous welfare states, people might invest in housing as a form of social protection to secure future retirement income (see Chapter 2 in (OECD, 2013 $\left.{ }_{[12]}\right)$. Figure 10 identifies clusters of countries with respect to public pension generosity, poverty, and homeownership. Public pension generosity is measured by net pension wealth, defined as the present value of the flow of pension benefits, taking into account the taxes and social security contributions that retirees have to pay on their pensions estimates (OECD Pensions at a Glance database). The main conclusion from this exercise is that there is no systematic link between homeownership and public pension generosity. Alternative indicators of pension generosity, such as net pension retirement rates, deliver qualitatively similar conclusions.

Countries in the top-left quadrant of Figure 10 - Belgium, Estonia, Hungary, Japan, Poland, Slovenia and the Slovak Republic - show below-average levels of public pension generosity and above-average rates of homeownership among the elderly. However, the rates of poverty among the elderly differ substantially across these countries. Countries in the top-right quadrant, Ireland, Greece, Spain and Portugal boast above-average levels of both homeownership and public pension generosity. Their poverty rates tend to be low and similar. Countries in the bottom-left quadrant, Canada, Chile, France, Korea, the United Kingdom and the United States, feature below-average levels of public pension generosity and homeownership. With the exception of France and Canada, the rates of poverty among the elderly tend to be relatively high. Finally, countries in the bottom-right quadrant, Austria, Germany, the Netherlands and Denmark show below-average levels of homeownership among the elderly combined with aboveaverage public pension generosity. These countries, particularly Denmark and the Netherlands, stand out for relatively low poverty rates among the elderly. 


\section{Figure 10. There is no systematic link between homeownership and public pension generosity}

Net pension wealth at half the average wage and homeownership in age group 65+

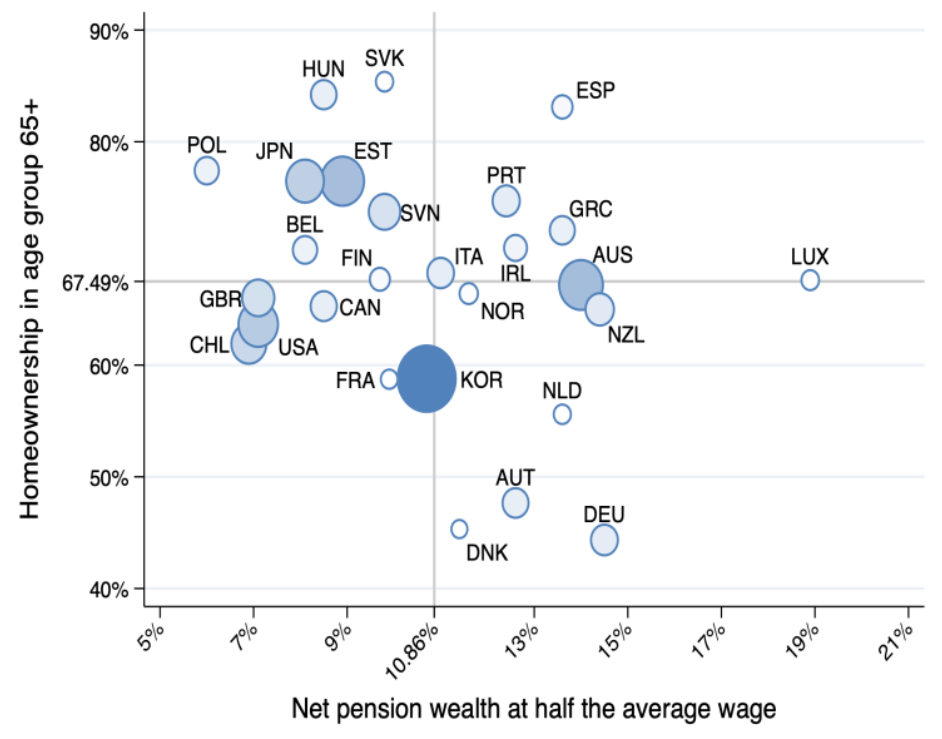

Note: Net pension wealth is the present value of the flow of pension benefits, taking account of the taxes and social security contributions that retirees have to pay on their pensions. It is expressed as a multiple of net annual individual earnings in the respective country. The size of the bubbles in the graph represents the scale of old-age poverty rates. The poverty threshold is set at $50 \%$ of median disposable income in each country. The income-based poverty rates exclude lump-sum payments which are frequent in the retirement schemes of some countries (e.g. Australia). Data refer to 2014.

Source: OECD Wealth Distribution Database (oe.cd/wealth), OECD Income Distribution database (https://stats.oecd.org/Index.aspx?DatasetCode=IDD), OECD Pensions at a Glance database.

\subsubsection{Mortgage debt: risks and opportunities}

One major reason why housing is the principle vehicle of wealth accumulation for the typical household is because it can be acquired with debt. ${ }^{17}$ Indeed, mortgage debt is the most important component of household debt (Figure 11). At the macroeconomic level, that is, considering all households in the population whether indebted or not, mortgage debt represents more than half of total household debt in almost all OECD countries. At the household level, that is, among households that hold mortgage debt, mortgage debt represents more than $80 \%$ of their total debt.

From a policy perspective, this makes it clear that monitoring household debt and housing market developments require a careful focus on mortgage debt. One lesson from the financial crisis is that mortgage debt entails opportunities but also risks, particularly for vulnerable households. This section sheds new evidence on the distributional incidence of mortgage debt..

${ }^{17}$ In line with the definition of housing as household main residence, mortgage debt refers to principal residence debt throughout the paper unless otherwise stated. 
Figure 11. At the macro and household level, mortgage debt is the largest part of household debt

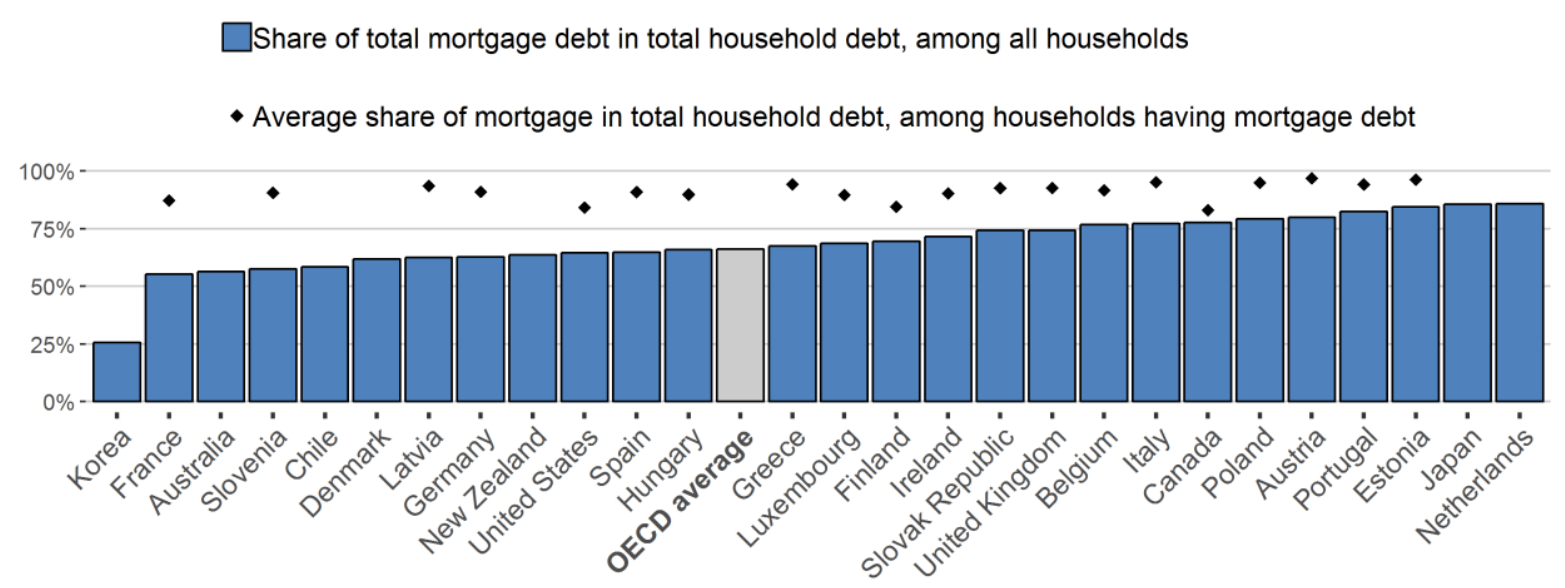

Note: How to read this figure: in France, at the macro level, that is, summing among all households whether indebted or not, mortgage debt represents $55 \%$ of total household debt; at the micro level, that is, among households having mortgage debt, mortgage debt represents on average $87 \%$ of their total debt. The numbers refer to principal residence debt only. Source: OECD Wealth Distribution Database (oe.cd/wealth), HFCS database.

The proportion of households that hold a mortgage varies significantly across OECD countries (Figure 12, Panel A). On average across the OECD, around 25\% of households have mortgage debt, ranging from around $10 \%$ in Slovenia and Italy to between 40 and $50 \%$ in the United States and the Netherlands. One key stylised fact is that the participation in mortgage debt increases broadly monotonically with household income (Figure 12, Panel B). This is not surprising as mortgage markets are regulated and bank lending is conditional on household repayment capacity, measured primarily by their level of income. Yet the link between household income and mortgage debt is somewhat steeper in some countries than in others. This may be indicative of differences in prudential regulation of mortgage markets on the borrower and on the lender side, in addition to housing affordability.

Access to mortgage debt for young household is likely to be one key driver of homeownership for this group, given their relatively low current wealth and income. Indeed, across OECD countries, the higher the participation in mortgage markets among young households, the lower is the difference in homeownership between young and the rest of the population (labelled homeownership age spread) (Figure 13). The literature shows that young households are relatively more sensitive than other groups to policy settings affecting homeownership, in particular mortgage market regulations (Andrews, Caldera Sánchez and Johansson, $\left.2011_{[11]}\right) .{ }^{18}$ Cross-country differences in homeownership age spreads are also likely to reflect differences in the dynamics of housing affordability. This has been emphasised recently in countries with large house price increases, such as the United Kingdom with the so called "broken housing market" and generational divide

\footnotetext{
${ }^{18}$ The literature is largely consensual on finding that young households are overly sensitive to mortgage market design and regulation in terms of e.g. loan-to-value and loan-to-income ratios. See e.g. (Chiuri and Jappelli, 2003 $3_{[50]}$ ) (Xiong and Mavropoulos, 2018[37]) (Andrews and Caldera Sánchez, $2011_{[22]}$ ). Young households are also overly sensitive to access to stable jobs, which largely condition access to (mortgage) credit.
} 
in homeownership whereby young households have been priced out of the market (IFS, $\left.2018_{[13]}\right)$.

Figure 12. OECD countries exhibit great variation in households' participation in the mortgage market, and participation increases with the level of household income

Panel A. Proportion of households with mortgage debt across OECD countries (\%)

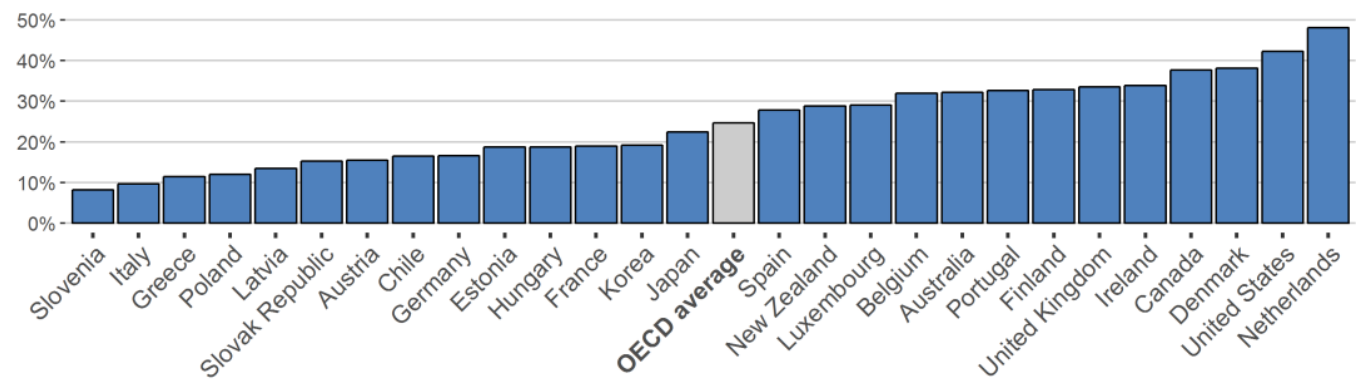

Panel B. Proportion of households with mortgage debt across the income distribution, OECD average and selected countries $(\%)$

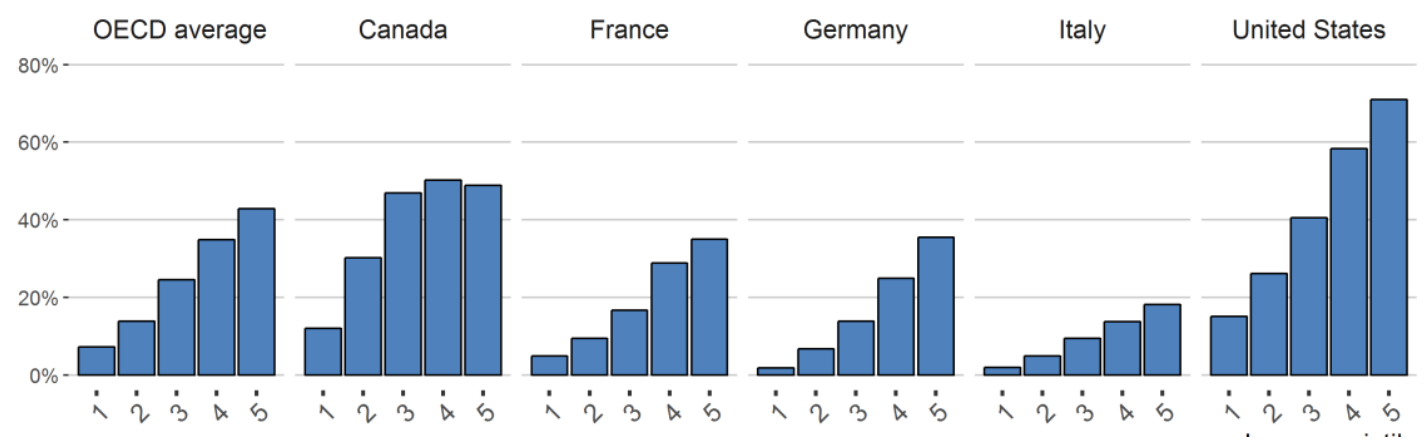

Note: The numbers refer to principal residence debt only.

Source: OECD Wealth Distribution Database (oe.cd/wealth).

Information on the distribution of mortgage debt across socioeconomic groups is important for determining vulnerabilities associated with the sensitivity of households to income losses, declines in house prices and increases in interest rates. Figure 14 analyses financial vulnerability associated with mortgage debt by focusing on three complementary prudential indicators $\left(\mathrm{ECB}, 2009_{[14]}\right)$ : the debt-to-income ratio, the loan-to-value ratio and the debt-to-service income ratio. These indicators are based on micro data, which allows for a focus on bottom income and wealth households as relevant at-risk population groups. The numbers should be taken with caution, given that samples are sometimes relatively small and may not be fully representative of the whole population. ${ }^{19}$ Still, these indicators provide a broad picture of financial vulnerability associated with mortgage debt.

Over the last decades, and in particular prior to the financial crisis, the strong expansion in mortgages led to an increase in the debt-to-income ratios for households with mortgage debt. This ratio is well above $100 \%$ in most OECD countries and it exceeds $200 \%$ in some of them such as Portugal, Spain and the Netherlands (Figure 14, Panel A). This is likely to partly reflect, at least for the Netherlands, the prevalence of interest-only and contractual savings mortgages which delay repayment of the principal (ECB, 2009 $\left.9_{[14]}\right)$. Households at

${ }^{19}$ The calculation is not performed for income and wealth groups in countries where underlying subsamples are considered as too small. This happens mostly in countries where a relatively low share of households hold mortgage debt (because the calculation is conditional on having mortgage debt). 
the bottom of the income distribution are particularly vulnerable, with debt-to-income ratios exceeding the conventional at-risk threshold value of $300 \%$. Associated risks seems to be particularly significant in some Anglo-Saxon countries (e.g. Canada and Australia). This may reflect the strong increase in house prices over the last decade, especially in Canada, triggering an increase in mortgage debt.

Figure 13. Participation in the mortgage market by young households tends to narrow the difference between homeownership among young and the rest of the population

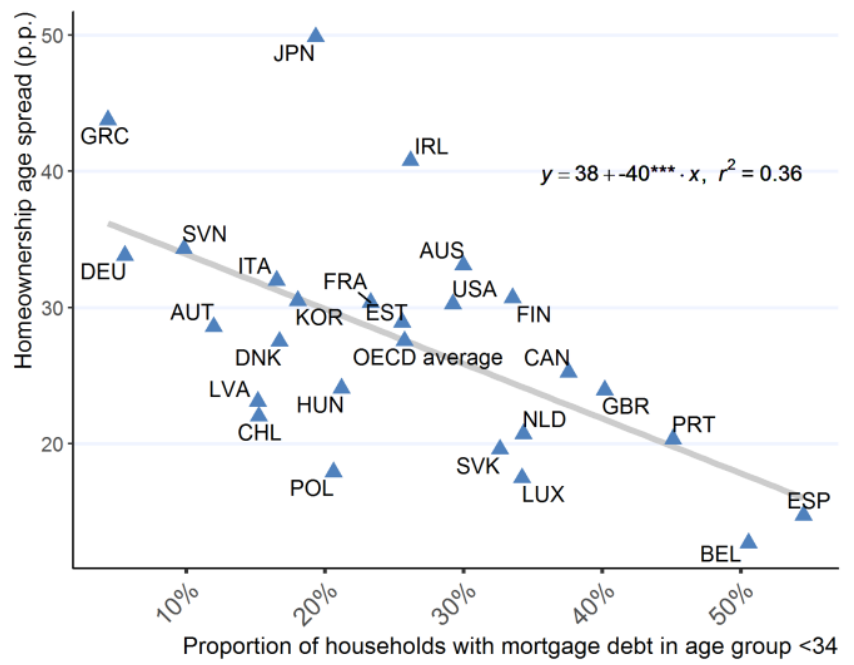

Note: Homeownership age group spread refers to the difference in homeownership rates between young households and all households. The numbers refer to principal residence debt only.

Source: OECD Wealth Distribution Database (oe.cd/wealth).

The loan-to-value ratio can be considered as a solvency risk indicator. It tracks households' ability to pay back their mortgages, assuming that their house can be sold at prevailing price if the household faces serious difficulties in repaying its debt. The highest values of this ratio, more than 50\%, are in Ireland, Portugal and the Netherlands (Figure 14, Panel B), potentially reflecting recent declines in house prices in these countries. The loan-tovalue ratio is highest at the bottom of the net wealth distribution, especially in countries characterised by widespread participation in mortgage debt. For indebted households in the bottom quintile of the net wealth distribution, loan-to-value ratios exceed the conventional at-risk threshold value of $75 \%$. While this is somewhat definitional as households at the bottom of the net wealth distribution are often the most indebted and/or those that experienced asset price depreciation, the conclusion is still that excessive leverage can expose vulnerable households to solvency risk in case of house price busts.

The debt service-to-income ratio can be considered as a liquidity risk indicator. It measures the amount of income that households pay for interest and to repay the principal. This indicator can be used for evaluating the vulnerability of households to changes in their capacity to reimburse mortgage debt in cases of various shocks to their income. Overall, the debt service-to-income ratio is well below the conventional at-risk threshold value of 40\% (Figure 14, Panel C). Hungary, Ireland, France, Portugal and Spain are countries where households at the bottom of the income distribution devote more than $40 \%$ of their income to service their mortgages. This could signal particular vulnerability to sudden drops in incomes and increases in interest rates when mortgages are taken out at variable rates. According to HFCS data, variables rates are prevalent in Portugal and Ireland (93.9\% 
and $86.0 \%$ respectively), slightly less so in Hungary (54.4\%), and relatively infrequent in France $(9.8 \%)^{20}$

Figure 14. Mortgage debt can expose households to financial vulnerability

$\square$ Among all households $\quad$ - Among households in the bottom income quintile
$\square$ Among households in the bottom wealth quintile

Panel A: Debt-to-income ratio, median

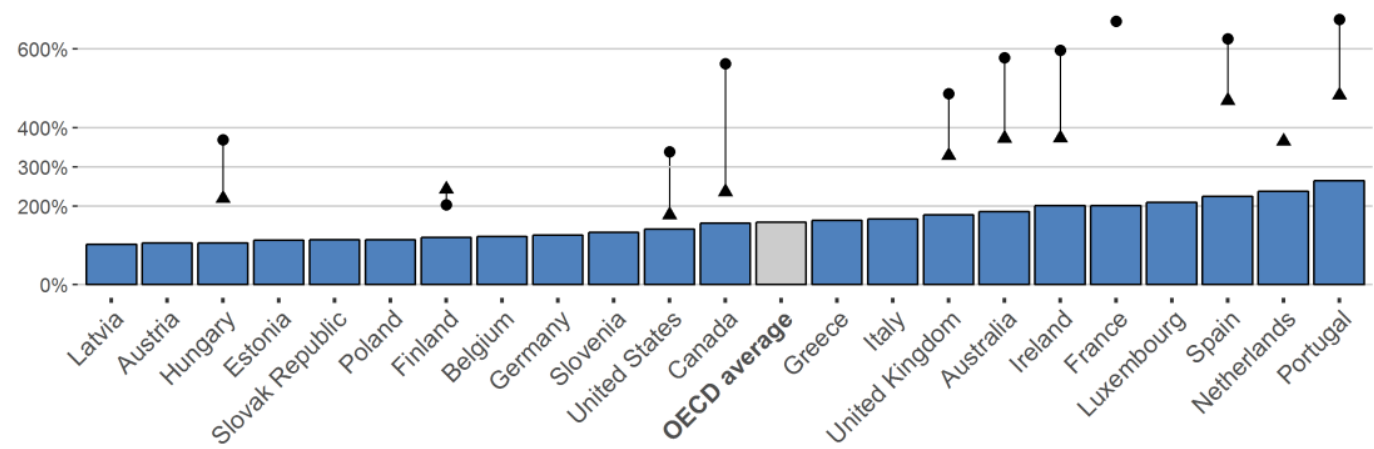

Panel B: Loan-to-value ratio, median

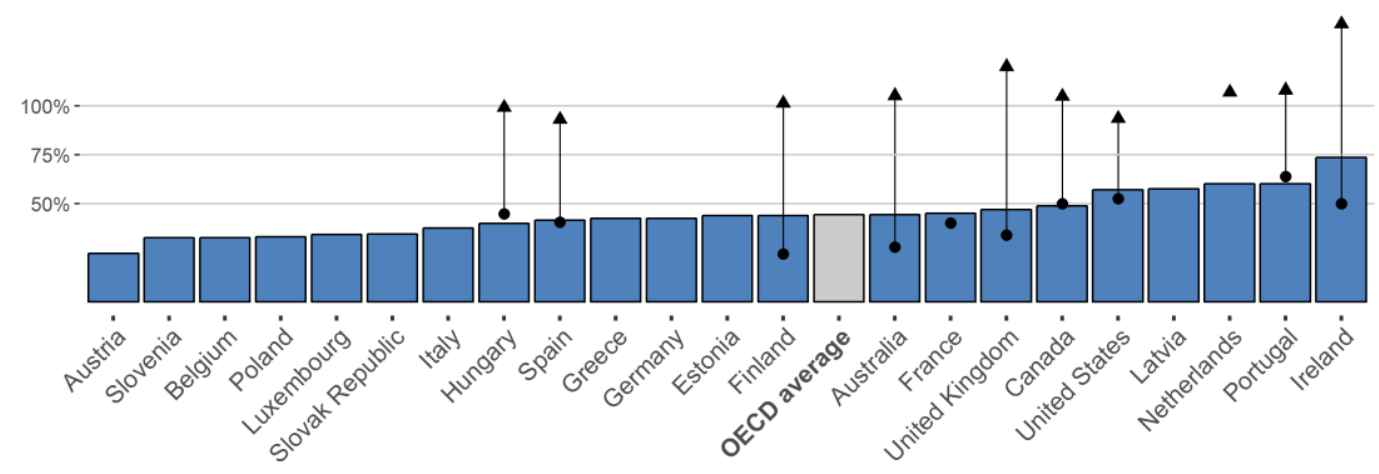

Panel C: Debt-to-service income ratio, median

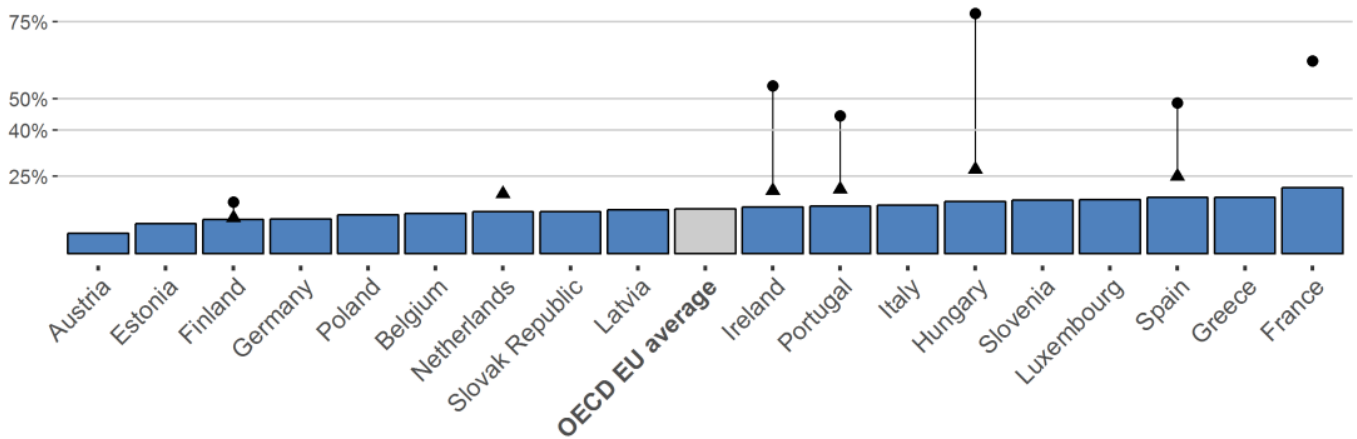

Note: The numbers refer to principal residence debt only. These ratios are calculated only for households with principal residence mortgages. The calculation is done only in cases where the number of observations exceeds 50, which is why some data is not shown for bottom income and wealth households. The debt service-to-income ratio calculation can only be calculated for European countries on the basis of HFCS data.

Source: HFCS database, LWS database.

${ }^{20}$ Nor shown for saving space, available upon request for European countries covered in HFCS. 
Another risk associated with mortgage markets is home equity-based borrowing. Mortgage instruments which allows for using the primary house as collateral for consumption purposes (mortgage equity withdrawal, reverse mortgages, etc.) were key drivers of the financial crisis. In short, US households borrowed against the rising value of their house between 2000 and 2007, expanding mortgage debt relative to income by a substantial amount. The subsequent bust in house prices amplified the contraction in consumption through the mortgage market collateral channel. Apart from the well-documented macroeconomic costs associated with mortgage equity withdrawal over the crisis period, ${ }^{21}$ loan defaults were mostly concentrated on low-income households, contributing to rising inequality and social distress, especially in areas experiencing major house price declines (Mian and Sufi, 2011 $1_{[15]}$ ). Cross cross-country evidence on the use of the primary house as collateral is scarce. ${ }^{22}$ Box 4 exploits the granular information available in wealth surveys to shed some preliminary light on this important issue.

\section{Box 4. Some insights on the use of the primary house as collateral}

Micro wealth surveys data allow to gain insights on the use of the primary house as collateral because respondents are asked what was the purpose of the primary house mortgage when they took it out. This allows for estimating the share of homeowners that use their primary house as collateral, defined as the percentage of homeowners that use primary house mortgages for purposes other than purchasing or refurbishing the primary house (Figure 15)

In the vast majority of OECD countries covered by the data, mortgages are used to buy (or renovate) the primary house (Figure 15). Less than $10 \%$ of homeowners use their primary house as collateral for non-housing purposes except in Australia and Canada. In Canada, the data suggest that more than $30 \%$ of homeowners use their house as collateral. This is likely to reflect the common use of Home Equity Lines of Credit (HELOCs) ${ }^{23}$ as documented by the Financial Consumer Agency of Canada (FCAC, 2017 ${ }_{[16]}$ ) and the data published by the Canada Mortgage and Housing Corporation ( $\mathrm{CMHC}$ ). Rising use of these instruments could partly be driven by rising house prices, that is, a collateral wealth effect on consumption.

One policy-relevant question is the extent to which the use of the primary house as collateral differ across income, wealth and age, as this could have implications in terms of vulnerability to income and interest rate shocks as well as consumption effects. The data suggest a higher tendency among high-income households to use the primary house as

${ }^{21}$ Home equity-based borrowing also has implications for the transmission of monetary policy: as housing becomes more liquid, interest rate movements are likely to result in higher wealth effects.

$22\left(\mathrm{ECB}, 2009_{[14]}\right)$ includes some analysis in section 3.2.6 of the report.

${ }^{23}$ HELOCs are revolving, and typically non-amortised, credit products secured by a lien on the borrower's residential property. The HELOC product first appeared in the late 1970s, but it was during the mid-1990s that lenders began tailoring HELOCs to appeal to a broader cross-section of consumers. Today, most HELOCs are sold as a component of readvanceable mortgages. Readvanceable mortgages combine HELOCs with amortized mortgages, and in some cases other credit products and banking services (e.g. personal loans, business loans, chequing accounts, overdraft protection and credit cards) under a global credit limit secured by a collateral charge against the borrower's property. 
collateral. Moving from income to wealth distribution delivers an opposite picture in a number of countries: in Canada, the United Kingdom, Latvia and Portugal, households at the bottom of the net wealth distribution are more likely to use their house as collateral. Finally, older households are less likely than younger households to use their house as collateral, suggesting that the use of instruments targeted at older homeowners such as reverse mortgages in the United States is not so widespread (Makoto, 2012[17]).

Figure 15. The use of the primary house as collateral is relatively uncommon in most OECD countries

Percentage of homeowners that use primary house mortgages for purposes other than purchasing or refurbishing the primary house

Panel A. The use of primary house mortgages for non-primary house purposes by income group

$\square$ Among all households

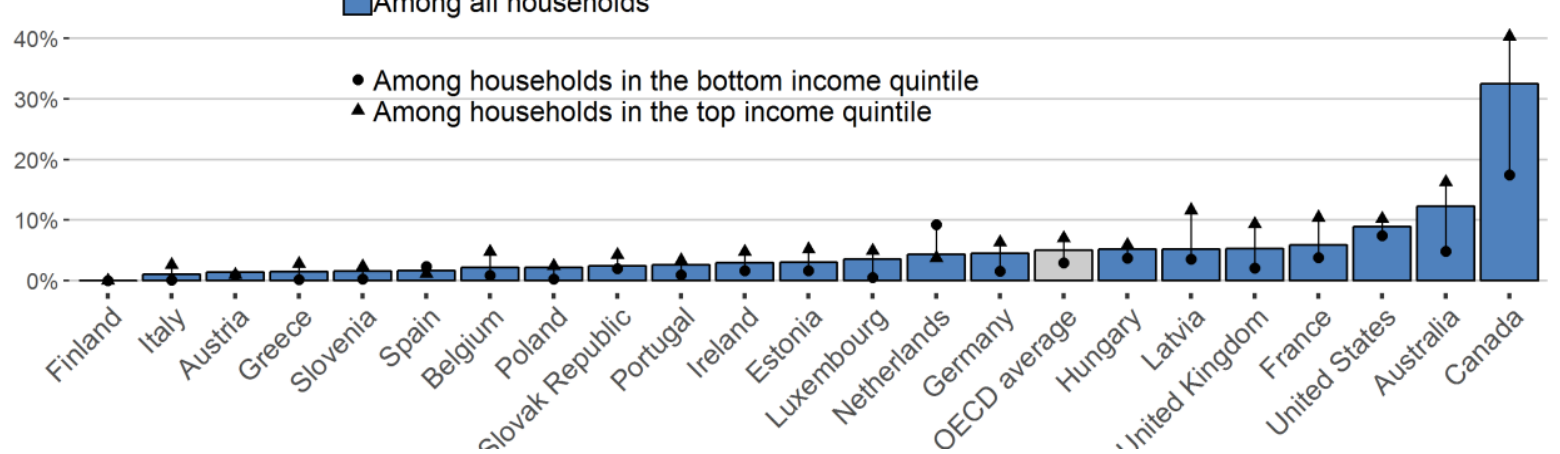

Panel B. The use of primary house mortgages for non-primary house purposes by wealth group

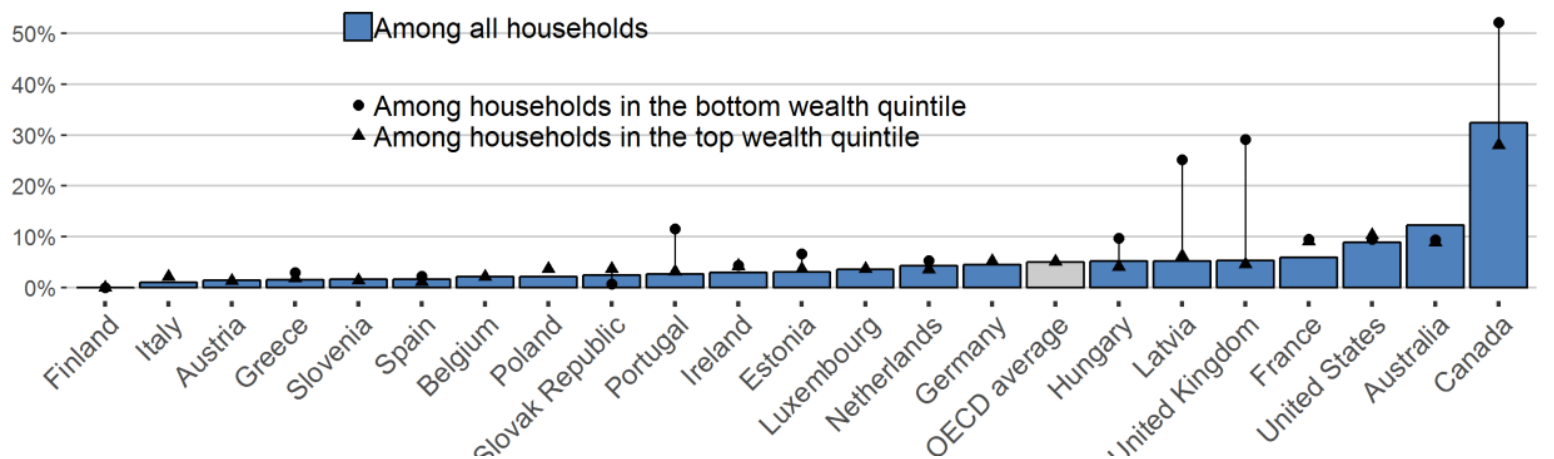

Panel C. The use of primary house mortgages for non-primary house purposes by age group

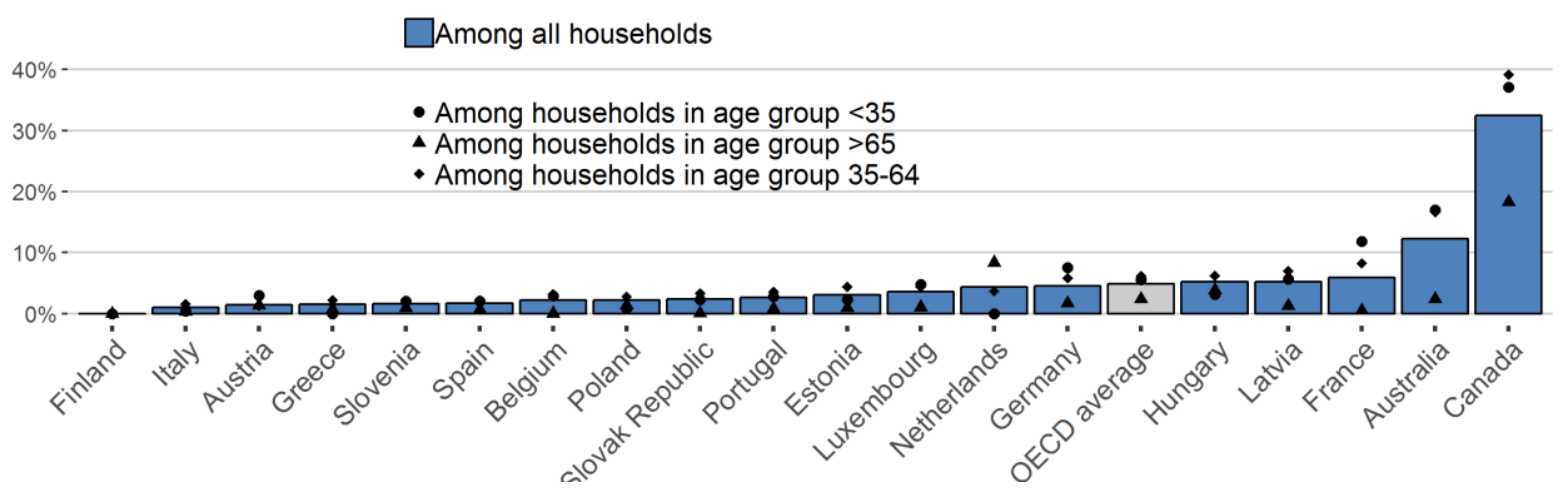

Note: The numbers refer to principal residence debt only. The figure shows the percentage of homeowners that declare to own primary house mortgages for purposes other than purchasing or refurbishing the house. This metric is not shown if the underlying sample is smaller than 50 observations. 
Source: Authors' calculations based on HFCS and LWS.

Across the majority of European countries, when households use their mortgage for nonhousing purposes, they tend to do so primarily for purchasing a secondary home (Figure 16). Another frequent purpose is to finance a business or professional activity, especially so in Italy, France, Greece and Spain (Figure 16).

Figure 16. Purchasing another real estate asset tends to be a major purpose for using the primary house as collateral in European countries

Purpose of primary house loans used for non-primary house purposes (in \%)

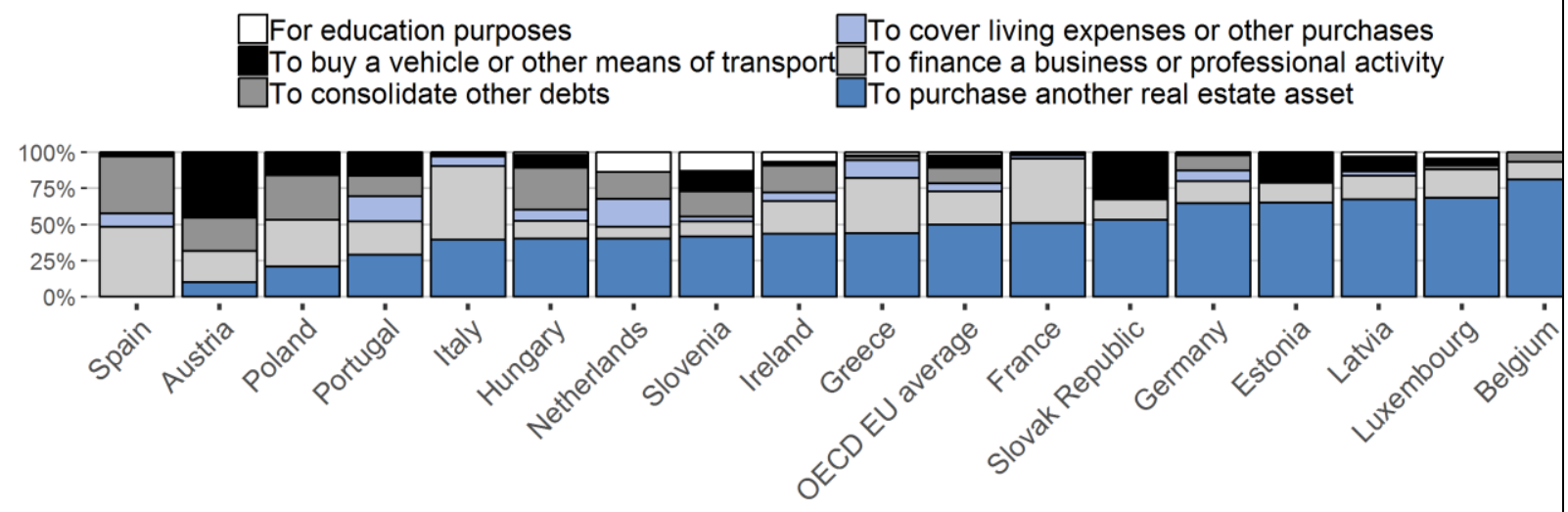

Note: The figure shows the major purpose of loans using the primary house for non-primary house purposes (i.e. among loans having a different purpose than purchasing or refurbishing the house) -- in \% of primary house mortgage loans. The information on the specific purpose of the loan is not available in LWS data.

Source: Authors' calculations based on HFCS.

The use of the primary house as collateral for buying another house may reflect leveragebased tax planning opportunities in the buy-to-rent market $\left(\mathrm{OECD}, 2018_{[18]}\right)$. In most OECD countries, mortgage interest is deductible on rental properties, while capital gains are also often taxed at reduced rates. Investing in immovable property, even in the absence of equity, can be attractive especially when housing markets are booming and investors are expecting a significant capital gain to make a positive return on investment. Such tax planning opportunities may have adverse efficiency and equity effects. They may lead to greater incentives to purchase residential property, hence capital misallocation and they may also contribute to rising leverage and house prices. Tax planning opportunities can have regressive effects. This is because tax planning are likely to benefit wealthiest households given the concentration of ownership of secondary houses at the top of the income and wealth distribution (Figure 17). Uncapped mortgage interest deductions can also play a role and are regressive as they provides a greater benefit to higher income households. 


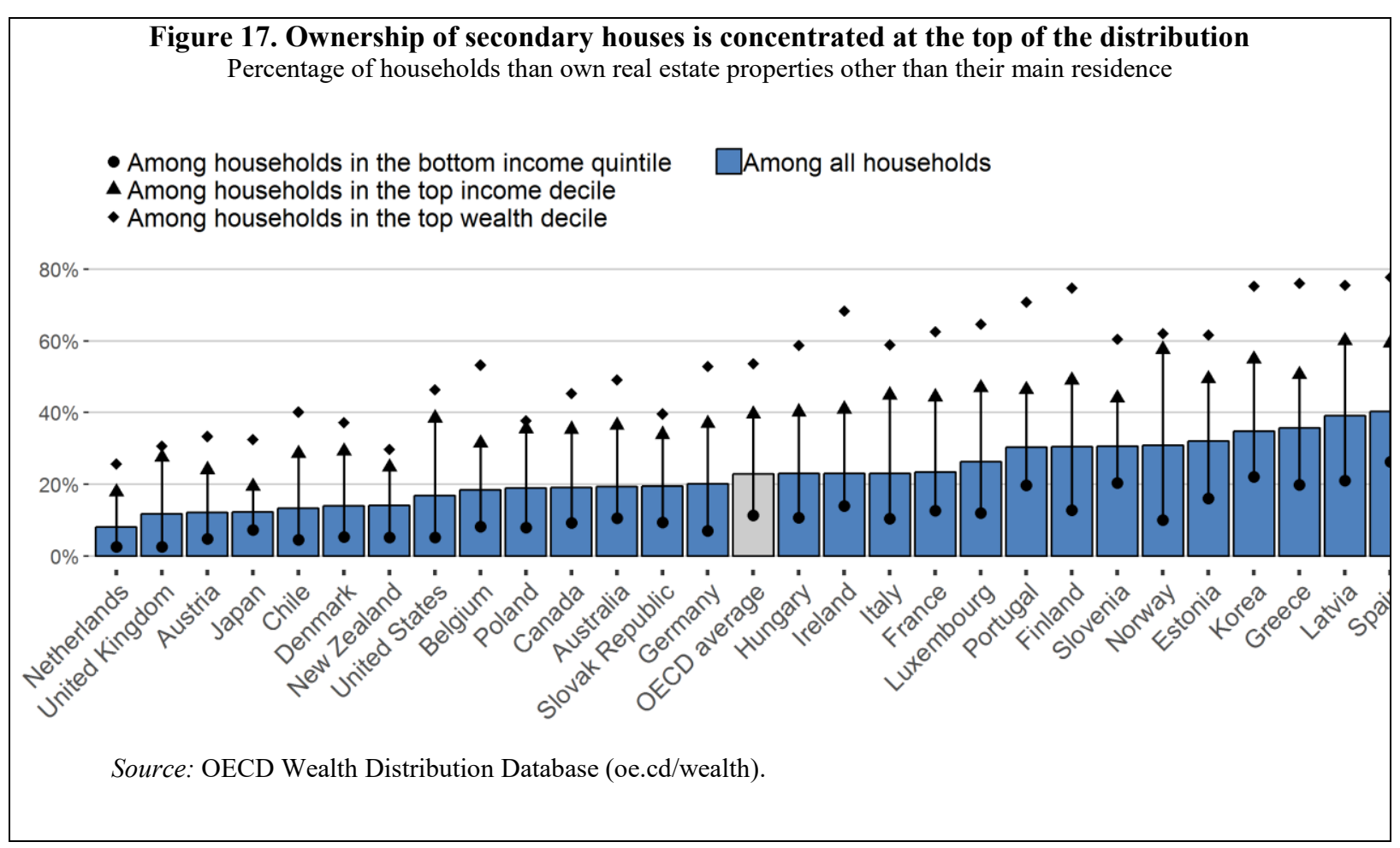

From a household perspective, mortgage debt is both an opportunity and a risk. On the one hand, it allows households, especially young households and those with little initial assets to accumulate wealth. On the other hand, it can expose households, especially those at the bottom of the distribution, to financial risks in the event of income losses, of house price declines as well as interest rates increases. The implication is that mortgage-related policies need to strike the right balance between allowing access to mortgage debt as an opportunity to accumulate wealth and preventing the building up of excessive leverage with potential large economic and social risks.

\subsubsection{Housing and wealth accumulation}

Having established the importance of housing in households' portfolios on the asset and liability side, one key question is whether housing is a vehicle for wealth accumulation. The argument that homeownership is an effective saving scheme and that it may result in a higher rate of wealth accumulation than otherwise often underpins public policy support for homeownership. This broadly reflects two mechanisms. First, a mechanical direct effect whereby housing is a major and often the only source of household wealth. Second, an indirect effect whereby becoming homeowner would stimulate the propensity to save and invest in other assets. This indirect effect is controversial, as causality from homeownership to wealth accumulation is difficult to establish. Taking into account this major caveat, one starting point to address this question is to measure the wealth gap between homeowners and renters, the so-called "tenure wealth gap". The results indicate that in all European countries covered in this analysis, homeowners have significantly higher levels of net wealth than tenants (Figure 18, Panel A). On average, the median net wealth of homeowners is almost 40 times than that of renters. The tenure gap is much lower when housing is excluded from household wealth. Yet a significant gap remains: on average across the countries considered, the median financial wealth of homeowners is around 5 times that of renters (Figure 18, Panel B). This may suggest that homeowners' and renters' 
propensity to accumulate assets likely differ systematically with respect to other factors than homeownership.

Figure 18. Homeowners tend to be wealthier than renters

Panel A. Median net wealth of homeowners relative to renters

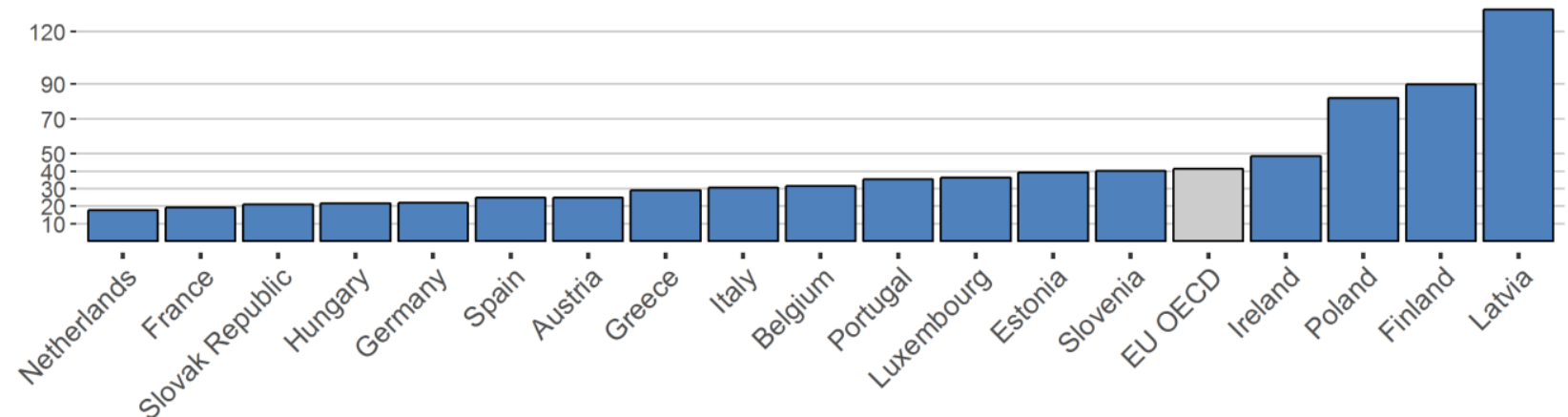

Panel B. Median financial wealth of homeowners relative to renters

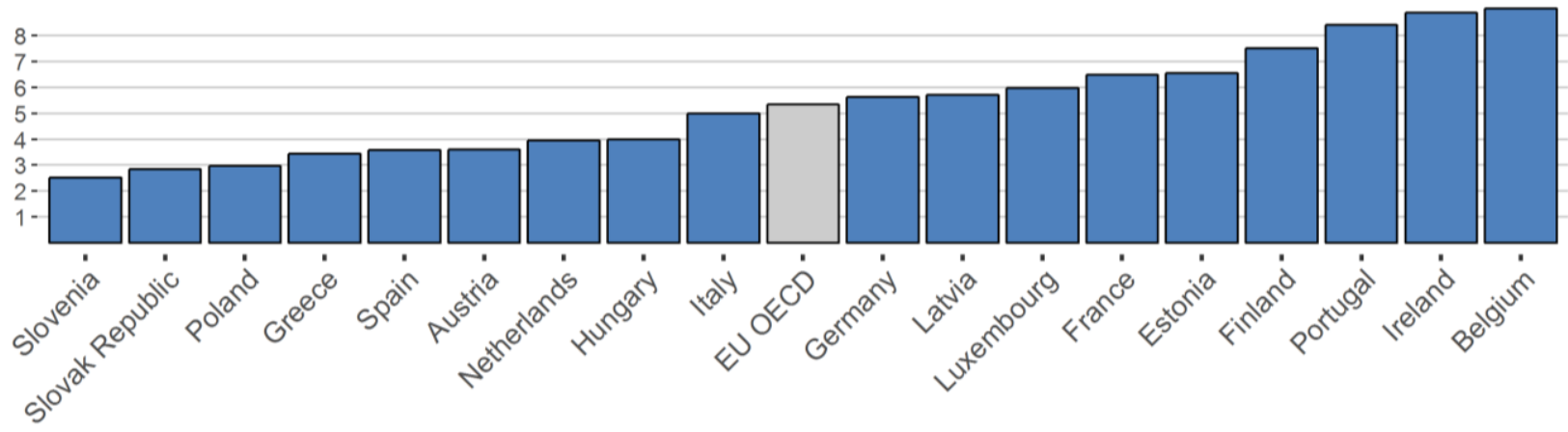

Source: HFCS.

To further dig into the question of homeownership and wealth accumulation, the analysis moves from descriptive statistics to quantile regression techniques (see Annex for detailed results) Median country-level and pooled regressions are run to estimate a model of wealth accumulation (e.g. (Arrondel et al., 2014 ${ }_{[19]}$ ) and (Wind and Dewilde, 2017 ${ }_{[20]}$ )) The estimated equation features housing tenure status and an extensive array of household-level explanatory variables such as age, household size, household income, education and labour market status of the reference person, as well as inheritance (i.e. whether a member of the household has received any gift or inheritance, whether the household main residence has been inherited). The results should be taken with care because the cross-sectional nature of the data makes it impossible to estimate a model of savings and wealth accumulation, which would require longitudinal data following households over time. The estimates suggest that the tenure wealth gap is significantly reduced in a controlled regression framework (Figure 19). The net wealth tenure gap remains higher than 10 in all European countries covered by the analysis. The financial wealth tenure gap is much lower but still significant in almost all European countries: all else equal, the median homeowner has around twice the level of financial assets than the median renter. 
Figure 19. The tenure wealth gap declines significantly in a micro-based regression framework

Panel A. Estimated net wealth tenure gap, homeowners relative to renters

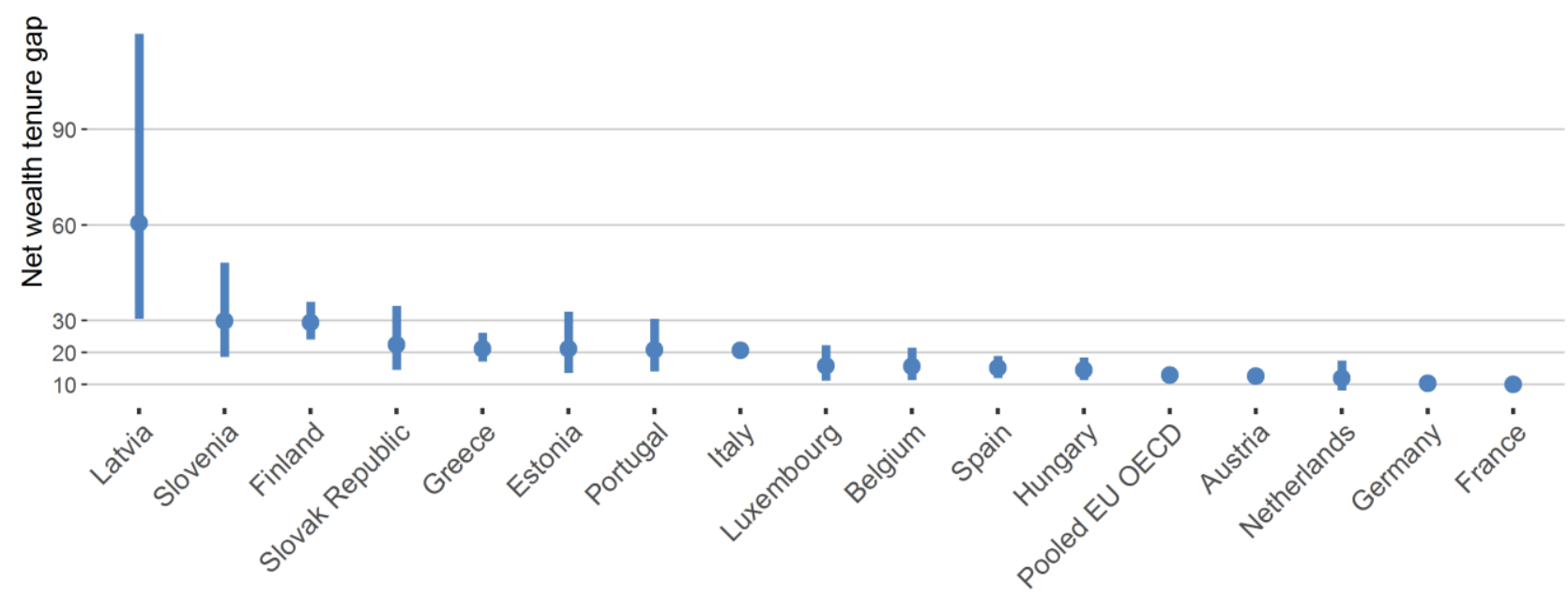

Panel B. Estimated financial wealth tenure gap, homeowners relative to renters

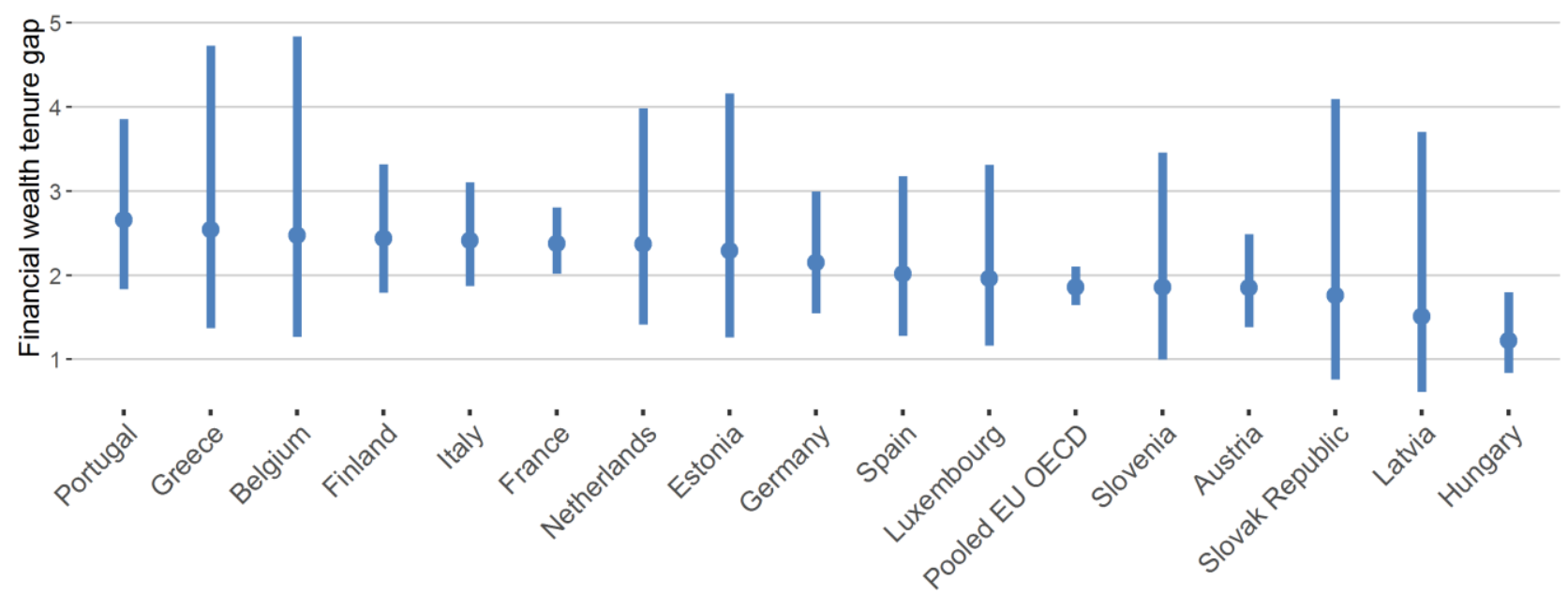

Note: How to read this figure: in the Netherlands, conditional on household socio-demographic characteristics as well as on whether one household member has received the house or other assets as inheritance, the median homeowner has 11.8 times more overall net wealth than the median renter and twice more financial wealth than the median renter. Median country-level regressions using inverse hyperbolic transformation in $\log$ form. Results adjusted for multiple imputations. Household-level control variables include age and households size, education, labour market status, income, inheritance of the house, inheritance of other assets, and housing tenure status (owner/renter). "Pooled EU OECD" refers to crosscountry fixed effects regressions. Vertical bars refer to the $90 \%$ confidence interval. See Annex for detailed results and estimates.

Source: Authors' calculations based on HFCS.

These findings do not strongly support the existence of a causal effect of homeownership on wealth accumulation to the extent that the tenure wealth gap declines significantly after the inclusion of relevant household-level controls. Rather, they are likely to reflect selfselection mechanisms. Households with an ex-ante higher propensity to save and appetite for wealth accumulation select themselves into homeownership rather than becoming homeowner making them more prone to accumulate wealth. This is supported by the 
finding that tenure wealth gaps are significant in all countries and that they decline dramatically when controlling for household characteristics.

Cross-country differences in tenure wealth gaps are likely to reflect a wide array of mechanisms which cannot be identified in the current framework. For instance, they may reflect differences in rates of return on investment in housing and other assets, hence house price dynamics affecting asset building and consumption, including the use of the main house as collateral (see Box 4). Tenure wealth gaps may also reflect differences in housingrelated policies that influence the user-cost of housing services (e.g. for tenants the rent, for homeowners property taxes, the mortgage payments and maintenance cost, minus the depreciation of the house). In countries that subsidise homeownership, homeowners would be able to accumulate more wealth than their counterparts in countries that do not subsidise owner-occupation. One cautious implication would be that the case for encouraging homeownership as a way to accumulate wealth is not so compelling, especially considering associated potential costs in terms of risks from excessive leverage, partial capitalisation of support in housing prices and reduced incentives for residential mobility.

\subsection{Housing and wealth distribution: policy discussion}

Promoting homeownership is a policy objective for many governments and public policy tends to favour ownership relative to renting and other investment, typically via the preferential tax treatment of owner-occupied housing (Salvi del Pero et al., 2016 [21] (Andrews and Caldera Sánchez, 2011 $1_{[22]}$ ). The main economic argument for favouring homeownership over renting is that it may give rise to positive spillovers for society, for instance because homeownership is a vehicle for wealth accumulation, leads to better outcomes for children, and is associated with more community engagement and voting behaviour. Empirical evidence does not consensually support the existence of these channels: a common problem is establishing causality since correlation between homeownership and a variable of interest may reflect the influence of a third omitted factor and self-selection bias, as discussed in the previous section.

Still, the argument that homeownership provides the most stable tenure arrangement to satisfy basic household needs could justify pursuing higher homeownership as a public policy goal. Yet this policy goal can conflict with other policy goals such as efficiency, by distorting labour and capital from their most productive use; unemployment reduction by slowing down labour adjustment in a downturn; and social mobility throughout the lifecycle and across generations by discouraging people to relocate and benefit from new opportunities.

Informed by the stylised facts on housing wealth, this section takes stock of existing empirical evidence to frame a preliminary policy discussion on housing and wealth distribution. The focus is on those areas that have direct implications for the outcomes documented in the analysis which implies that some important housing-related polices are not covered here. A broader set of policies will be covered in the Horizontal Housing project. 


\subsubsection{Reforming property taxes to make the overall tax system more progressive and efficient ${ }^{24}$}

\section{Shifting the tax mix towards property taxes}

Reforms to shift the tax burden towards property taxes have been increasingly advocated to switch to a more growth and equity-friendly tax system. Country-specific recommendations along these lines are often formulated in the context of Economic Surveys and Going for Growth (OECD, 2019 $\left.{ }_{[23]}\right)$. The case for shifting towards property taxes is based on vast empirical evidence showing that greater reliance on property taxes boosts growth and tend to reduce or have neutral effects on income inequality. From an efficiency perspective, recurrent taxes on immovable property (i.e. taxes levied regularly on the ownership of immovable property) have been found to be the least damaging to economic growth followed by consumption taxes, other property taxes, personal income and corporate income taxes (Brys et al., 2016[24]), (OECD, 2010[25]). Compared with recurrent taxes on immovable property, non-recurrent taxes on immovable property, e.g. property transaction taxes, can have distortionary effects, for instance by discouraging the owner of a house from moving to an area with better labour market opportunities. But, transaction taxes can have the advantage of discouraging speculative behaviour and thereby cooling down house prices. From a distributional perspective, (Akgun, Cournède and Fournier, 2017 ${ }_{[26]}$ ) have recently found that greater reliance on recurrent taxes on immovable property has no effect on disposable income inequality and that greater reliance on inheritance taxes tends to reduce disposable income inequality.

Despite their growth and equity benefits, OECD countries make little use of property taxes (Figure 20). Overall, property taxes make up slightly more than $5 \%$ of tax revenues on average, ranging from less than $2 \%$ in Estonia, Austria, the Slovak Republic and Slovenia, to around $10 \%$ in Korea, Canada and the United Kingdom. The share of property tax revenues in the OECD average tax mix has declined over time, reflecting the widespread repeal of net wealth taxes, inheritance and gift taxes as well as the failure to update property values (OECD, 2018 [27]). All in all, there is scope for shifting the tax burden towards property taxes across the OECD. Such reforms would be particularly relevant in countries where the tax mix is particularly skewed towards income relative to property (Figure 21).

24 This section relies on the principles set out on tax design for inclusive growth in (Brys et al., $\left.2016_{[24]}\right)$. 
Figure 20. OECD countries have ample room to shift the tax burden towards property taxes

Tax revenue from property taxes in $\%$ of total tax revenue

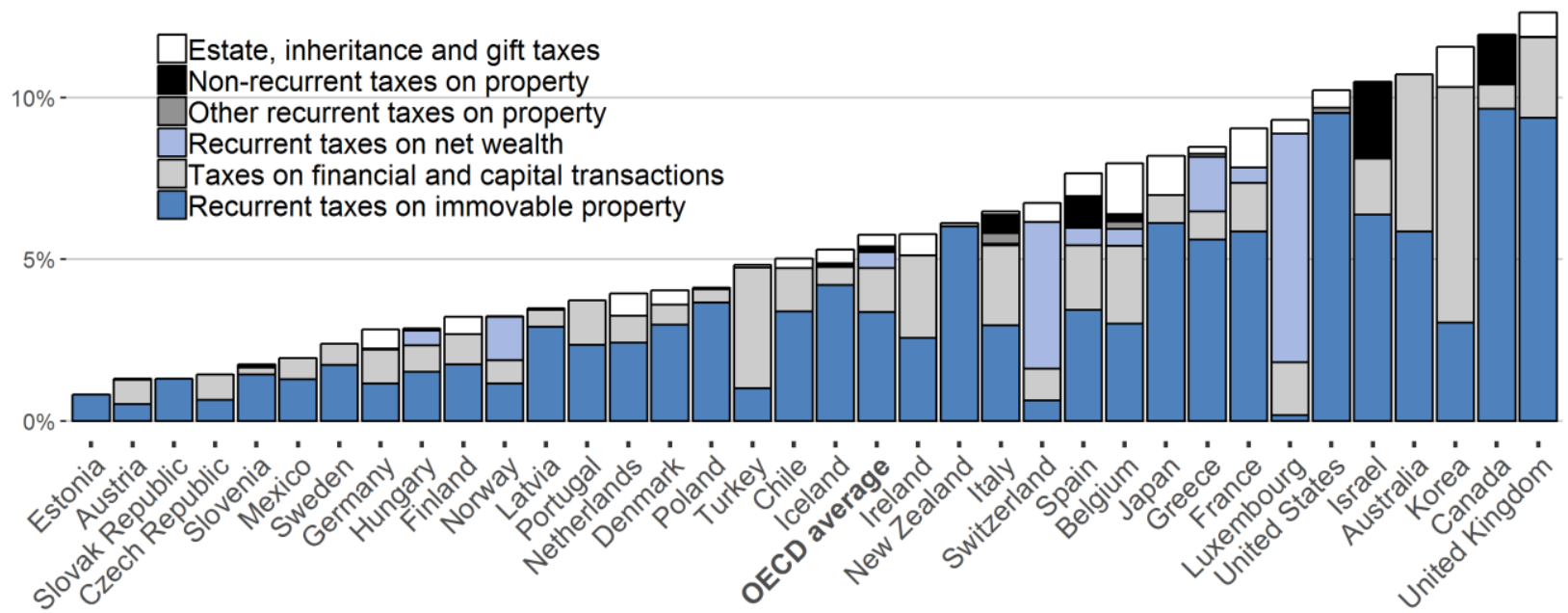

Source: OECD Tax Revenue Statistics.

Figure 21. Some countries could move away from taxing income to taxing immovable property and inheritance

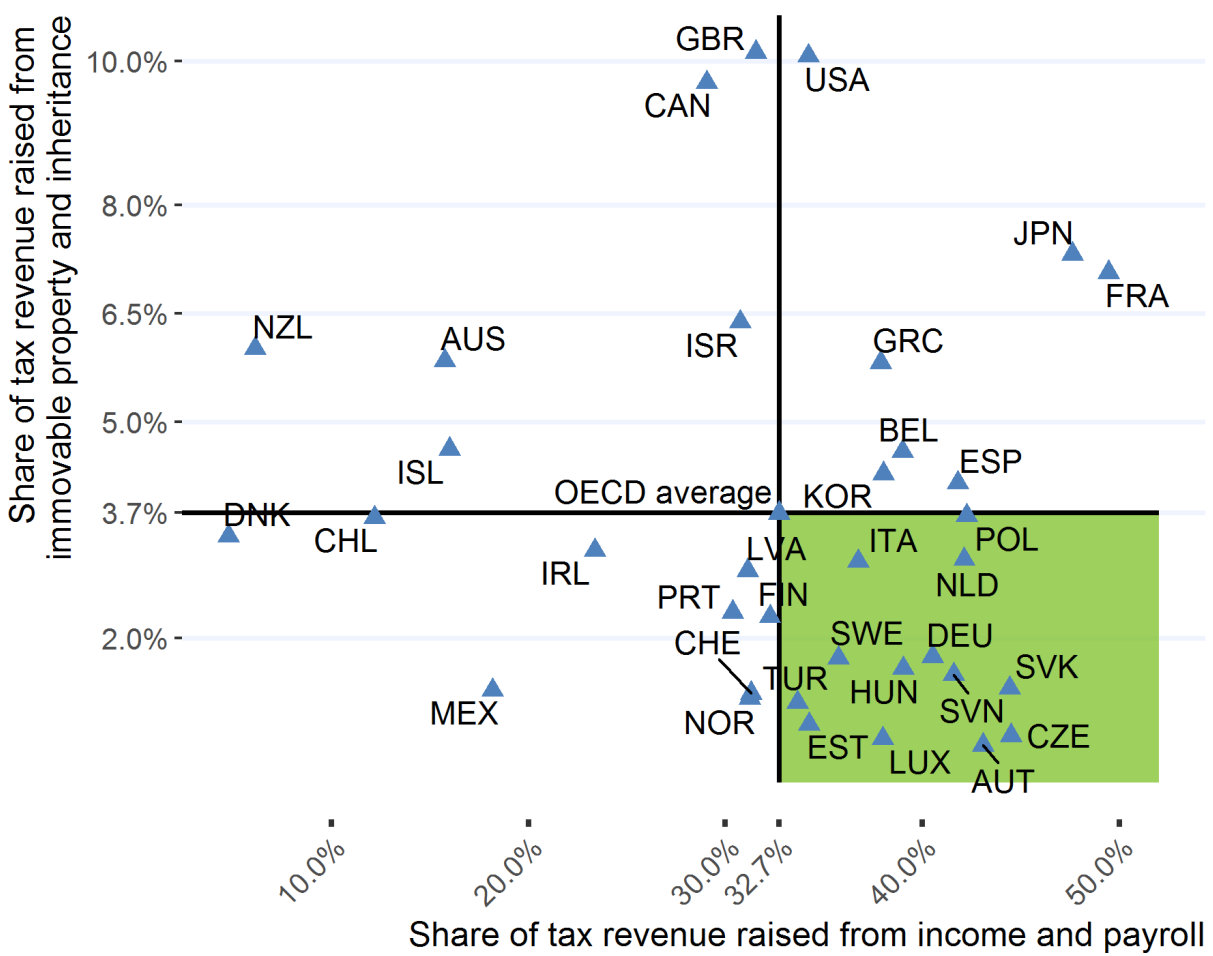

Note: Share of tax revenue raised from labour, capital income, social security contributions and payroll (categories 1000, 2000, 3000 of OECD Tax revenue statistics); share of tax revenue raised from recurrent taxes on immovable property and on estate, inheritance and gift (categories 4100, 4300 of OECD Tax revenue statistics).

Source: OECD Tax Revenue Statistics. 


\section{Enhancing the efficiency and progressivity of immovable property taxation}

Housing taxation can be made more efficient and progressive. Owner-occupied residential property is highly tax-favoured in the majority of countries compared to other forms of household savings, with the exception of retirement plans (OECD, 2018 $\left.8_{[18]}\right)$. This is due to the exemption of imputed rent and of capital gains from taxation, while mortgage interest is often deductible. This favourable tax treatment of owner-occupier property is economically inefficient by creating several distortions in terms of investment decisions, capital and labour allocation, and excessive leverage (Fatica and Prammer, 2017[28]).

Equity considerations would not either justify the favourable tax treatment of owneroccupier property which is unlikely to benefit low-income people most. In particular, the literature has shown that mortgage interest rate deductibility has in most cases a regressive impact (Fatica and Prammer, 2017 $[28]$ ). This reflects the fact that high-income households are much more likely to finance their house with mortgage debt, as documented in this paper (Figure 12). Another argument against mortgage interest rate deductibility is that generous tax relief can be capitalised in house prices, thereby redistributing income from new entrants in the housing market to insiders (Andrews, Caldera Sánchez and Johansson, $\left.2011_{[11]}\right)$.

The presumption that the favourable tax treatment of owner-occupied housing is regressive/flat is confirmed by comprehensive modelling of property taxation. New estimates of marginal effective tax rates on various components of household savings and wealth show that in most countries owner-occupied property taxes are not progressive $\left(\mathrm{OECD}, 2018_{[18]}\right)$. This is illustrated in Figure 22 which provides estimated average effective tax rates on owner-occupied housing for three income levels: 67, 100 and 500\% of the average wage. In most OECD countries the tax rates are flat across the distribution and in the United States they are even higher for low-income households.

Figure 22. Owner-occupied property taxes could be made more progressive

Marginal effective tax rates on owner-occupied residential property (\%)

- $100 \%$ of average wage $-500 \%$ of average wage $-67 \%$ of average wage

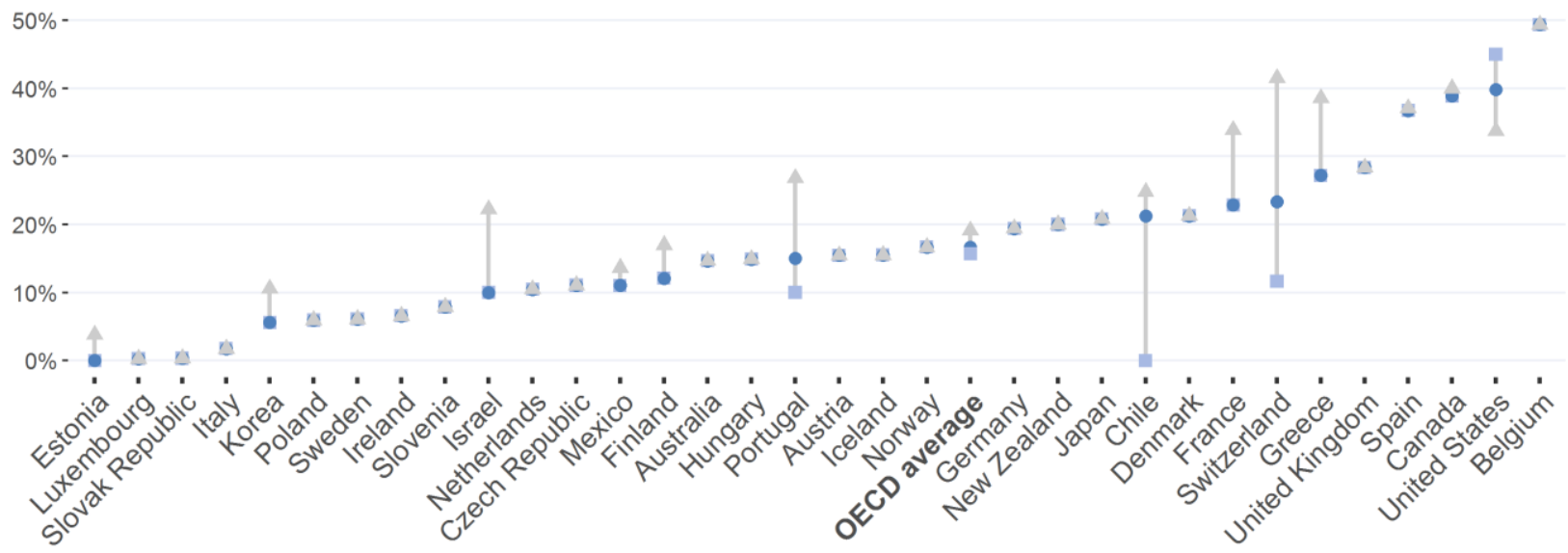

Note: Estimates from (OECD, 2018[18]). Marginal effective tax rates on owner-occupied residential property, equityfinanced. Personal tax rate: 67,100 and $500 \%$ of the average wage (AW). These taxes include recurrent taxes on immovable property, transaction taxes, possible taxes on income and capital gains taxes, when applicable. See (OECD, 2018 [18]).

Source: (OECD, 2018[18]). 
Housing should ideally be taxed in the same way as other assets, by taxing imputed rental income while allowing for mortgage interest deductibility. In practice, few countries tax imputed rental income, and using recurrent property taxes as a substitute is most often not sufficient as these taxes are not large enough to offset the mortgage subsidy. In these cases a "second best" approach is to remove mortgage subsidy or to scale up recurrent property

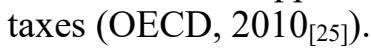

Removing or reducing mortgage interest rate deductibility would increase the progressivity of the tax burden on owner-occupied property. ${ }^{25}$ This removal should be done gradually in order to prevent a crash in house prices insofar as mortgage deductions tend to be capitalised in house prices (Andrews, Caldera Sánchez and Johansson, 2011 $1_{[11]}$ ). If removing mortgage interest rate deductibility is not an option, granting the rebate as a capped tax credit (i.e. a capped reduction of the tax liability), rather than a tax allowance (i.e. a reduction of the taxable income) is one way to make the tax relief less regressive. A more direct way to achieve progressivity in owner-occupied property taxation is to apply a progressive recurrent tax rate schedule, as well as to introduce a tax allowance or incometested property tax credit. Another approach is to allow deferral of the tax payment until death of the taxpayer or sale of the property for older taxpayers, but one major drawback in this case is the risk of lock-in effects. OECD countries have used these type of measures to increase the progressivity of their property taxes (Brys et al., 2016[24]).

Increases in recurrent taxes on immovable property need to be accompanied by regular updating of property values to market values. Denmark recently introduced a property tax reform which includes a new system for housing valuation and replaces a nominal freeze of property taxes with proportional taxation, maintaining a progressive element for the most valuable homes (OECD, 2019 [29]). Reforms in this area can be designed to address liquidity constraints for people with low incomes and non-liquid assets, for instance by making it possible to spread tax payments throughout the year or by introducing escrow accounts.

Going further, tax reforms to shift from labour to immovable property taxation are likely to enhance tax efficiency, progressivity and labour market inclusiveness in countries where the taxation of low wages is relatively high and the taxation of owner-occupied property for high-income households relatively low (Figure 23). This implies recurrent taxes on immovable property featuring generous allowances and a progressive tax schedule, especially when homeownership is widespread.

25 The current low interest environment may strengthen the case for removing mortgage deductibility. 
Figure 23. Higher progressivity in the tax system could be achieved by raising owneroccupied property taxes at high-income levels while reducing labour taxation at low-income levels

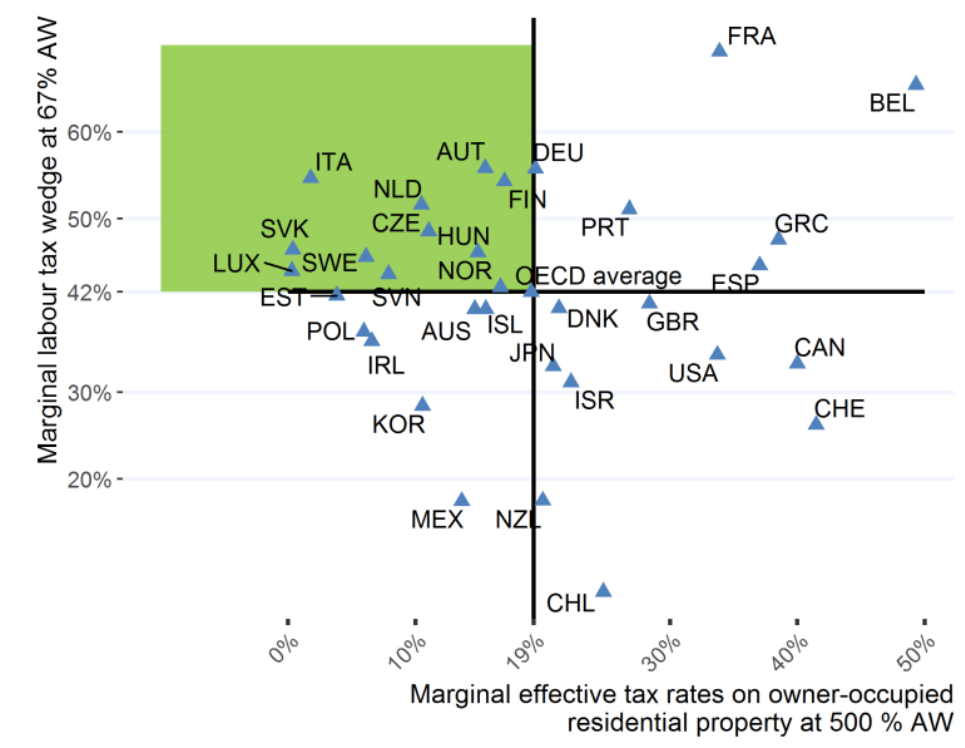

Note: Marginal labour tax wedge is defined as marginal personal income tax and social security contribution rate on gross labour income. Marginal effective tax rates on owner-occupied residential property, equity-financed.

Source: OECD Tax Database and (OECD, 2018[18]).

There is also scope to review taxation of secondary and rented residences. As already discussed, the distribution of other real estate is extremely unequal (Figure 24), with households in the top $10 \%$ of the net wealth distribution owning $34 \%$ of net housing wealth and $69 \%$ of net other real estate wealth. Available tax indicators suggest that the taxation of other real estate is higher and more progressive than that of owner-occupied residential property $\left(\mathrm{OECD}, 2018_{[18]}\right)$. Comparing the marginal effective tax rates on owner-occupied residential property relative to those on rented property suggest that: i) marginal effective tax rates on rented property are significantly higher than those for primary residences because of the non-taxation of imputed rental income as opposed to actual rental income and because most countries apply capital gains tax to rented residential property; and ii) marginal effective tax rates on rented property tend to be progressive across the income distribution because rental income is most often taxed at progressive marginal personal income tax rates.

The fact that rented property exhibits higher and more progressive taxation compared with owner-occupied property does not necessarily imply that reforms in this area are not needed. For example, Box 4 has discussed that the ability to debt-finance a property may open-up tax planning opportunities that benefit wealthier households the most. Real estate is also a potential asset class that can be attractive for hidden wealth. More broadly, how to tax the buy-to-let property market at the individual and corporate level is becoming a topical question, for instance given the increasing presence of institutional investors and buyers in globalised cities that have experienced rising house prices (see Chapter 3 in (IMF, $\left.2018_{[30]}\right)$ ). More work needs to be done to properly document the policy features at stake, but reviewing the taxation of real estate investments -- in the broader context of alternative investment vehicles -- is warranted on efficiency, equity and resilience grounds. 
Figure 24. Household main residence and other real estate: a tale of two inequalities

Share of net housing wealth and of other real estate wealth held by the top $10 \%$ of the net wealth distribution (\%)

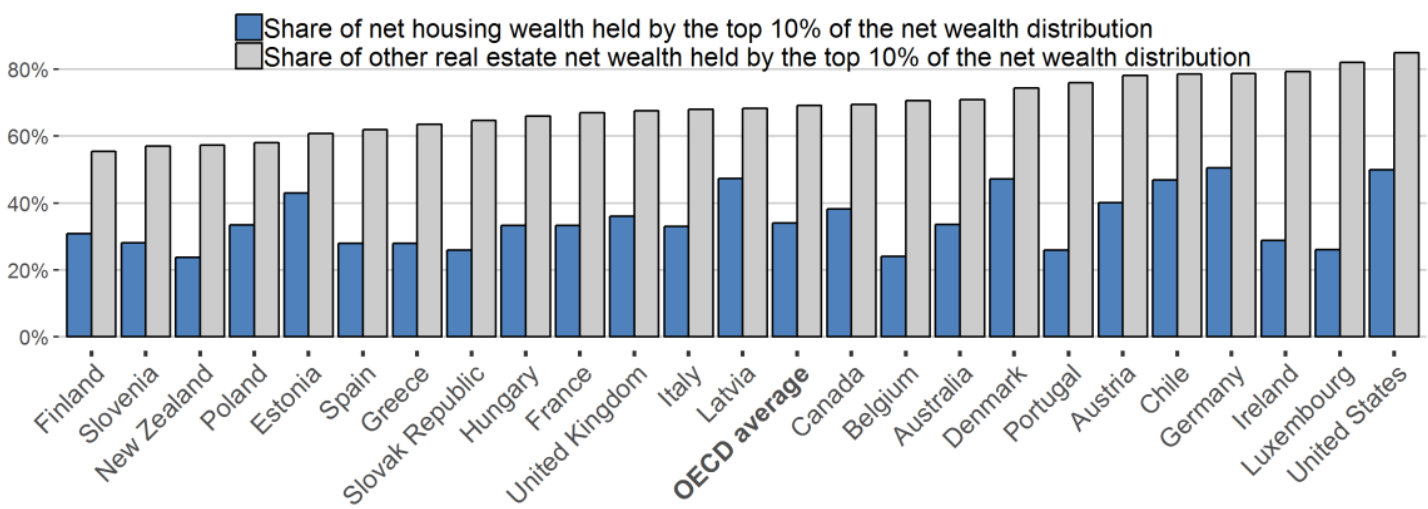

Note: Households are ranked by net wealth. Therefore, this figure shows the share of net housing /net other real estate wealth held by households at the top of the net wealth distribution.

Source: OECD Wealth Distribution Database (oe.cd/wealth).

\section{Taxing inherited wealth: the role of housing}

Taxing inherited wealth is justified on equity and efficiency grounds. From an equity perspective, well-designed inheritance taxes may increase intergenerational mobility and equality of opportunity by reducing and dispersing wealth holdings at death. Indeed, wealth transfers can be viewed as a source of opportunity that is not linked to the recipient's effort and that should therefore be taxed, regardless of whether the donor has already paid income tax or capital gains tax on the assets. In cases where the main residence is a significant portion of the estate's wealth, it may even not have faced income or capital gains taxes prior to the donor's death.

From an efficiency perspective, inheritance taxes tend to be less distortive than other forms of wealth taxation as e.g. their effects on savings are smaller than in the case or recurrent taxes on personal net wealth. ${ }^{26}$ Another argument in favour of inheritance taxes is that the double taxation argument is weaker than for recurrent taxes on net wealth, as there is no double taxation of the donor and the inherited wealth is also only taxed once in the hands of the recipient. Finally, inheritance taxes are also easy to administer and comply with as they are only levied once. A recent report on net wealth taxes argues that capital income taxes alone will most likely not be enough to address wealth inequality and suggests the need to complement capital income taxes with inheritance taxes (OECD, 2018 [27]).

Despite the strong case for wealth transfer taxes, revenues from inheritance or estate and gift taxes are very low and have been declining over time on average in OECD from 1.1\% of total taxation in 1965 to $0.4 \%$ today $\left(\mathrm{OECD}, 2018_{[27]}\right)$. Low revenues reflect the fact that inheritance/estate and gift tax bases are often narrowed by numerous exemptions and deductions, and avoidance opportunities are widely available. The decline in tax revenues also reflects the fact that a number of countries have either abandoned or scaled back their wealth transfer taxes. However, differences across countries - for instance with higher revenues collected in Belgium and France - suggest that the revenue potential of these taxes could be further exploited in many countries.

26 (Akgun, Cournède and Fournier, 2017 $[26]$ ) find net wealth taxes have a negative effect while inheritance taxes have no effect on long-term output. 
Designing efficient and fair wealth transfer taxes calls for progressive inheritance taxes. This involves taxing large inheritances but not taxing or taxing at low rates small inheritances received by poor taxpayers as well as allowing for deferred payments and instalments to address liquidity constraints. One question is whether inheritance taxes should involve a favourable tax treatment when the transmitted asset is the home in which the recipient lives. ${ }^{27}$ Such treatment could take the form of a higher exemption threshold for the home than for other assets transmitted. This may be justified on distributional grounds as low-income households tend to inherit their house while high-income households tend to inherit other assets (Figure 25).

Figure 25. High-income households have much higher chances of inheriting other assets than the main residence

Odds ratio of inheriting: high-income relative to low-income households

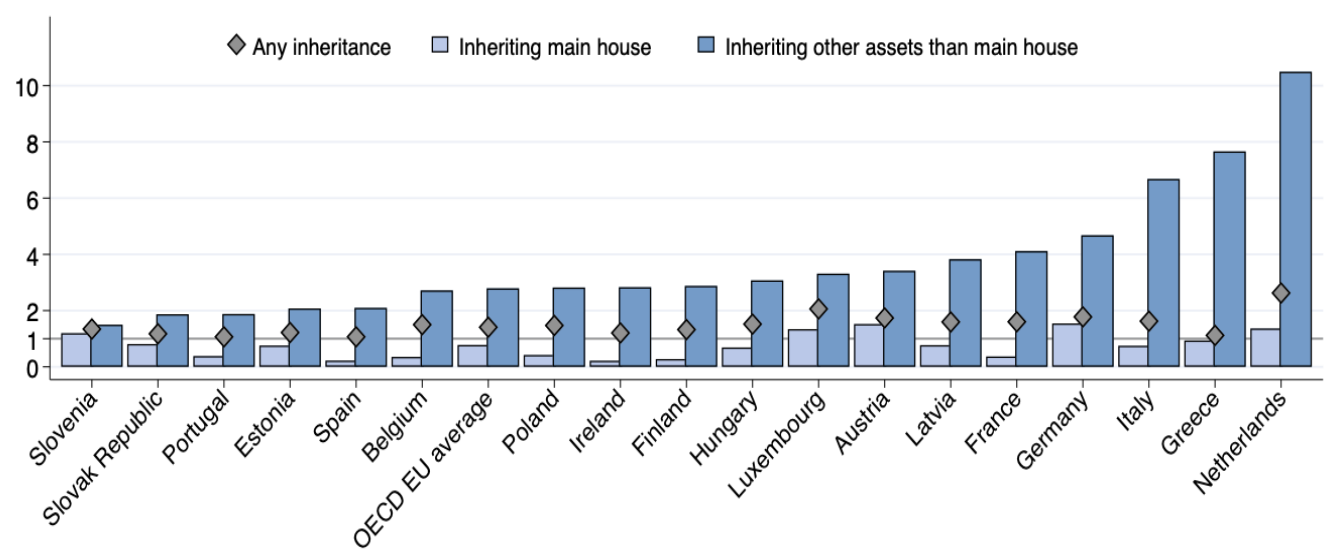

Note: High and low incomes refer to top and bottom income quintiles. How to read this figure: in the Netherlands, households in the top income quintile are 2.6 times more likely to receive any inheritance or gift than households in the bottom income quintile, households in the top income quintile are 1.3 times more likely to receive the main residence as inheritance or gift than households in the bottom income quintile, households in the top income quintile are 10.5 times more likely to receive assets other than the main residence as inheritance or gifts than households in the bottom income quintile.

Source: HFCS.

Among countries that have inheritance taxes, the main residence generally receives special treatment in the form of higher tax-exemption thresholds (e.g. the United Kingdom), preferential valuation rules (e.g. France) or even full exemptions under strict rules on usage of the home (e.g. Ireland). The level of the general inheritance tax exemption threshold is often used to ensure that small inheritances can be passed on tax-free. In addition, there can be measures to address liquidity constraints when it comes to the payment of inheritance tax on the main residence, such as allowing tax payment deferral until the property is sold for individuals who still occupy the home or allowing tax payments in instalments.

${ }^{27}$ Other important questions arise in the design of inheritance taxes, such as the treatment of familyowned business. These questions are beyond the scope of this paper. 
Figure 26. Across European countries, housing inheritance is negatively correlated with inheritance tax revenues

Inheritance/gifts of housing and non-housing assets and tax revenue raised from inheritance and gift taxes

Panel A. Proportion of households having received their house as inheritance or gift in age group $<35$ and tax revenue raised from inheritance and gift taxes,

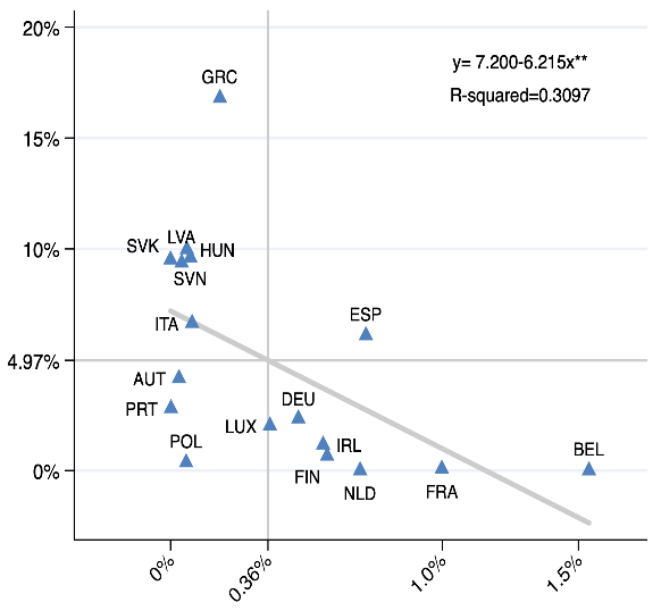

Tax revenue raised from inheritance and gift taxes ( $\%$ of total tax revenue)

Panel B. Proportion of households having received assets other than their house as inheritance or gift in age group $<35$ and tax revenue raised from inheritance and gift taxes

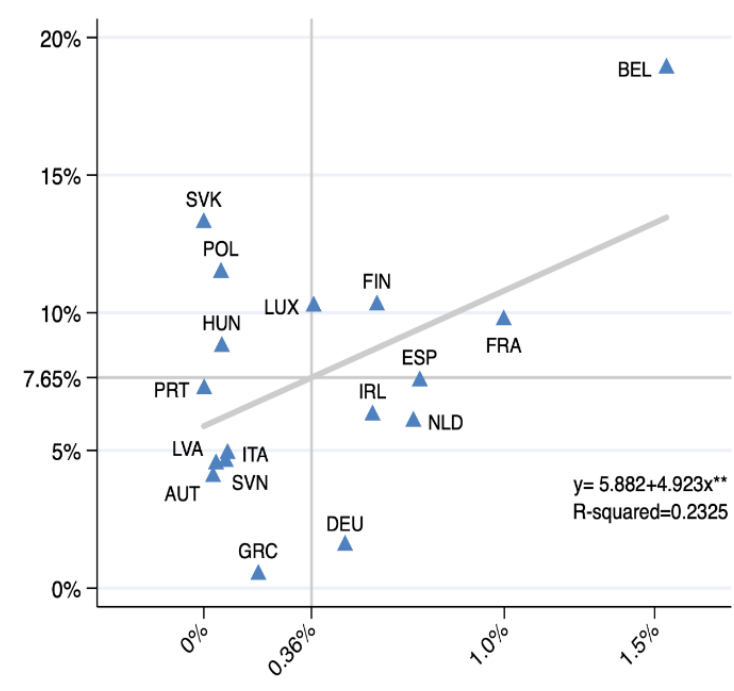

Tax revenue raised from inheritance and gift taxes (\% of total tax revenue)

Note: Tax revenue from estate, inheritance and gift taxes, average over the period 2009-2014.

Source: HFCS and OECD Tax Revenue database.

Full exemption of the main residence from inheritance taxes is likely to have regressive effects by allowing rich households to transmit expensive houses for free. It may also open up tax planning opportunities (e.g. providing incentives to hold more wealth in housing in anticipation of favourable inheritance tax treatment). Moreover, it risks locking-in recipients in their house, thereby reduce residential mobility. Indeed, the data indicate that 
households that have received their house as inheritance or gift tend to be less mobile than those that have acquired it. ${ }^{28}$ Finally, this exemption will narrow the tax base and reduce revenues from inheritance taxes on houses $\left(\mathrm{OECD}, 2018_{[27]}\right)$. In fact, across European countries, inheritance tax revenue is negatively correlated with inheritance of the main residence and positively correlated with inheritance of other assets (Figure 26).

\section{Political economy considerations in housing taxation}

Political economy considerations affect the design and implementation of housing taxation. One reason why OECD countries make little use of immovable property taxes and even less of inheritance taxes is because those taxes are highly unpopular and distributional concerns are major reform obstacles. To start with, this paper has shown that housing is the chief asset of the middle class: ${ }^{29}$ in virtually all OECD countries, the median voter is a homeowner. Concern is often raised that property taxes impose an unfair burden on middleincome families because middle-income families tend to hold a high proportion of their wealth in the family home whereas top earners may hold a significant proportion of their wealth in more liquid assets that are not subject to property taxes. Concern is also raised about the impact of inheritance taxes on asset-rich but cash-poor households, especially in the case where the house is being inherited; a substantial tax bill combined with a low income may result in a property needing to be sold in order to pay the tax. These concerns are not unjustified:

- While being homeowner drastically reduces the risk of being asset poor, it does not affect the risk of being income poor (Figure 27).$^{30}$ Going further, in a number of OECD countries, especially high-ownership ones such as Eastern European countries, Spain and Japan, homeowners are over-represented among the incomepoor (Figure 28).

- Housing is transmitted from one generation to the other and in most European countries more than one in five low-income homeowners have inherited their house (Figure 29).

\footnotetext{
${ }^{28}$ Not shown to save space. However, causality is hard to infer, as lack of mobility could reflect other confounding factors such as low education.

${ }^{29}$ For a discussion on housing and the middle class see e.g. (Wolff, 2017 [56]

${ }^{30}$ One potential limitation and explanation of this finding is that the income poverty measure used here does not include imputed rents. This definition of income poverty is in line with standard practice due to the difficulty of properly estimating imputed rents in a comparable way across countries.
} 
Figure 27. Being homeowner reduces the risk of being asset-poor but not the risk of being incomepoor

Share of individuals that are income poor, asset-poor and income \& asset poor, OECD average

\section{$\square$ owner $\square$ Renter}

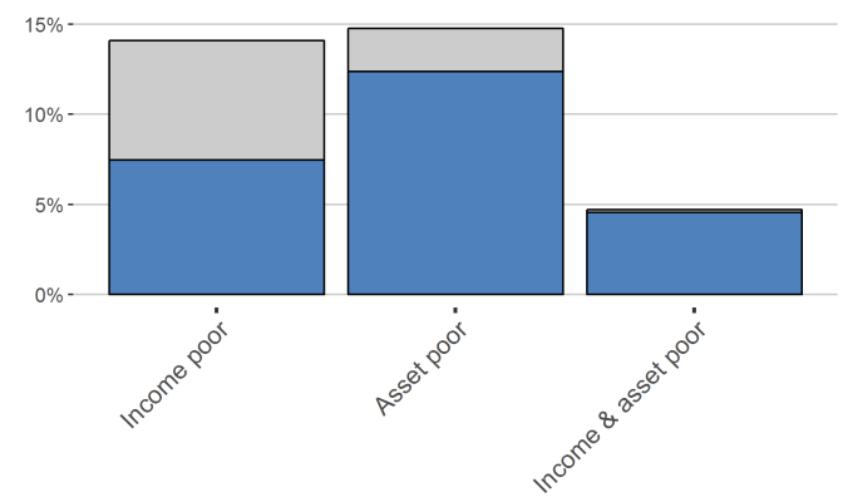

Note: For the purpose of poverty measurement, both income and wealth are equalised so that the unit of analysis is the individual. i) income-poor individuals are defined as those with equivalised annual income below the income poverty line $(50 \%$ of median); ii) asset-poor individuals are defined as those with equivalised net worth insufficient to cover 3 months of income poverty line; and iii) income and asset poor individuals as those with equivalised net worth insufficient to cover 3 months of income poverty line and with equivalised annual disposable income below the income poverty line. Different wealth concepts and reference periods can be used to derive asset poverty measures, which has an impact on the estimated poverty levels. For instance, when net wealth is used, measures of asset based poverty are around $2 / 3$ lower than those based on the liquid financial wealth concept. As expected, the share of the population identified as asset poor increases with longer reference periods, although the relative ranking of countries is insensitive to the reference period used. (See (Balestra and Tonkin, 2018[3]) for details)

Source: OECD Wealth Distribution Database (oe.cd/wealth).

Figure 28. Homeowners are over-represented among the income-poor in some OECD countries

Housing tenure mix of income-poor households (in \%)

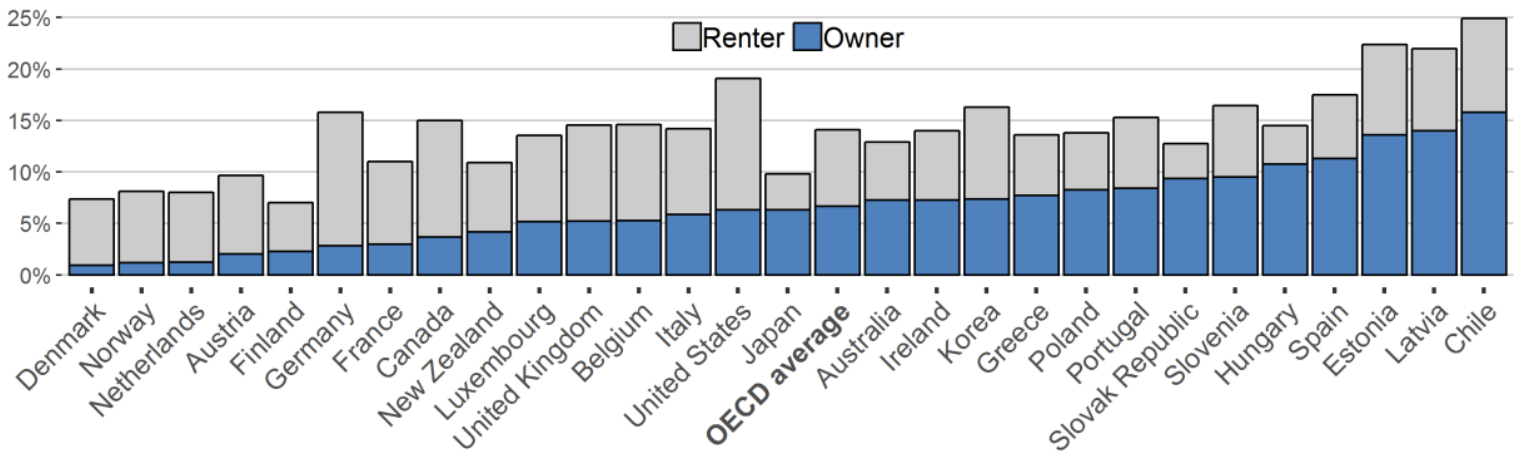

Note: How to read this figure: in Chile, $25 \%$ of individuals are income-poor, out of which $15 \%$ are owners and $10 \%$ renters.

Source: OECD Wealth Distribution Database (oe.cd/wealth). 
Figure 29. In most European countries, more than one in five low-income homeowners have inherited their house

Proportion of homeowners having inherited or received as gift their house across the income distribution

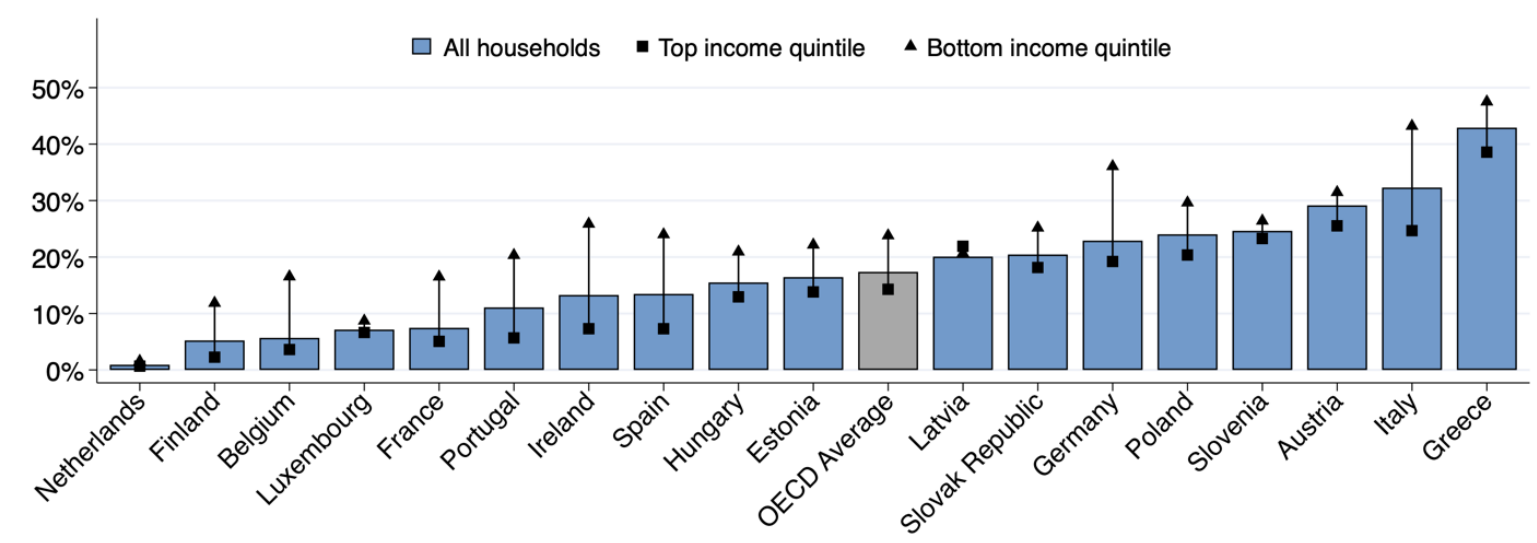

Note: How to read this figure: in Germany, $23 \%$ of homeowners have inherited their house, $36 \%$ of homeowners in the bottom income quintile and $19 \%$ of homeowners in the top income quintile have inherited their house.

Source: HFCS.

Still, as discussed, housing taxation reforms can be designed in a way that address these obstacles, ultimately producing a more efficient and more progressive tax system. There is no one-size-fits all approach and tax reform will depend on country-specific context, challenges and social preferences.

\subsubsection{Housing policy reforms to promote resilience and labour mobility}

\section{Reducing household-level vulnerabilities through prudential regulation}

This paper has shown that access to mortgage debt allows households with little assets a chance to own their own home and to accumulate wealth, but it can expose households at the bottom of the distribution to financial vulnerabilities. This section discuss preliminary policy implications focusing on borrower-based prudential policies alongside their potential differential effects across the distribution (see (Alam et al., 2019 [31] $)$ for recent evidence on the effects of loan-targeted instruments on aggregate household credit and consumption).

The implementation of borrower-based prudential regulation may raise distributional concerns. As shown in this paper, borrowers with high loan-to-value ratios are concentrated at the bottom of the wealth distribution, and borrowers with high loan-to-income ratios at the bottom of the income distribution. Subsequently, caps on loan-to-value and debt-toincome may exclude low-income and low-wealth households from the mortgage market. The down-payment constraint resulting from more restrictive caps will be particularly binding for first-time buyers and liquidity-constrained households, e.g. younger and lowincome households (see e.g. (Ortalo-Magne and Rady, 2006 $[32])$ ). Recent analysis by (Kelly, Le Blanc and Lydon, 2018 $8_{[33]}$ ) on the effect of tightening credit standards on the distribution of borrowers shows that European countries that experienced a boom-and-bust in the housing market saw the composition of buyers shifting from young and low-income to old and high-income households after 2010. 
However, distributional concerns associated with the implementation of borrower-based macroprudential policies are likely to disappear over a longer-term horizon. Excessive expansions of mortgage credit can trigger higher house price increases, which reduce housing affordability, and thus price out low-income households from the market. By curbing the joint increase of credit volume and house prices during leverage cycle booms, macroprudential caps may enhance housing affordability (see (Mian and Sufi, 2008 ${ }_{[34]}$ ), (Glick and Lansing, 2010[35]) (Kohl, 2018[36])).

The policy implication is that macroprudential policies can enhance micro resilience, especially for those households most vulnerable to price and income shocks. Even though associated credit constraints may prevent e.g. young households from accumulating wealth through homeownership, long-term positive gains are likely to outweigh short-term costs and therefore such instruments can be welfare improving by: i) preventing young households from prematurely investing in housing hence reducing vulnerability to price and income shocks, ultimately allowing better consumption smoothing (Xiong and Mavropoulos, 2018 ${ }_{[37]}$; and ii) more generally, contributing to housing affordability by curbing leverage-induced increases in house prices. The effectiveness of such instruments will ultimately depend on specific policy design: more data and work is needed to properly evaluate the micro distributional effects of macroprudential instruments.

\section{Promoting residential mobility by reducing relocation costs ${ }^{31}$}

The ease of moving residence geographically (e.g. across regions) has positive efficiency implications by enhancing the functioning of the labour market through the job-matching process and therefore the efficient allocation of human resources. It can also have positive inclusiveness implications, especially in from a dynamic perspective. Moving can be an opportunity for people from disadvantaged areas and backgrounds to find better jobs and achieve better quality of life, and available evidence tends to support this argument (Chetty, Hendren and Katz, 2016 $\left.6_{[38]}\right)$.

Ideally, housing markets and policies affecting them should not hinder residential mobility. The data used in this paper allow for shedding some light on this topical issue. Keeping in mind that the data do not allow to distinguish residential turnover within the same geographical area from geographical mobility, the evidence is that of a strong negative cross-country association between homeownership and households' mobility (Figure 30). ${ }^{32}$ In the average European country, $6 \%$ of households change their residence over a one-year period. Such mobility is low in high-ownership countries in the East and South of Europe, compared to low-ownership countries in the middle and North of Europe, where households move twice as often.

\footnotetext{
${ }^{31}$ Empirical evidence on the policy drivers of mobility reported here is based on previous OECD work by (Caldera Sánchez and Andrews, 2011 $\left.1_{[40]}\right)$ as well as on its recent extension by the World Bank in Chapter 3 of (World Bank, 2018[39]) .

${ }^{32}$ The sample is restricted to the age group 35-64 to reduce the impact of differences in demography notably in the share of older households. That said, country rankings are unaffected by using the whole sample.
} 
Figure 30. Across European countries, high homeownership is associated with low residential mobility

Homeownership and residential mobility

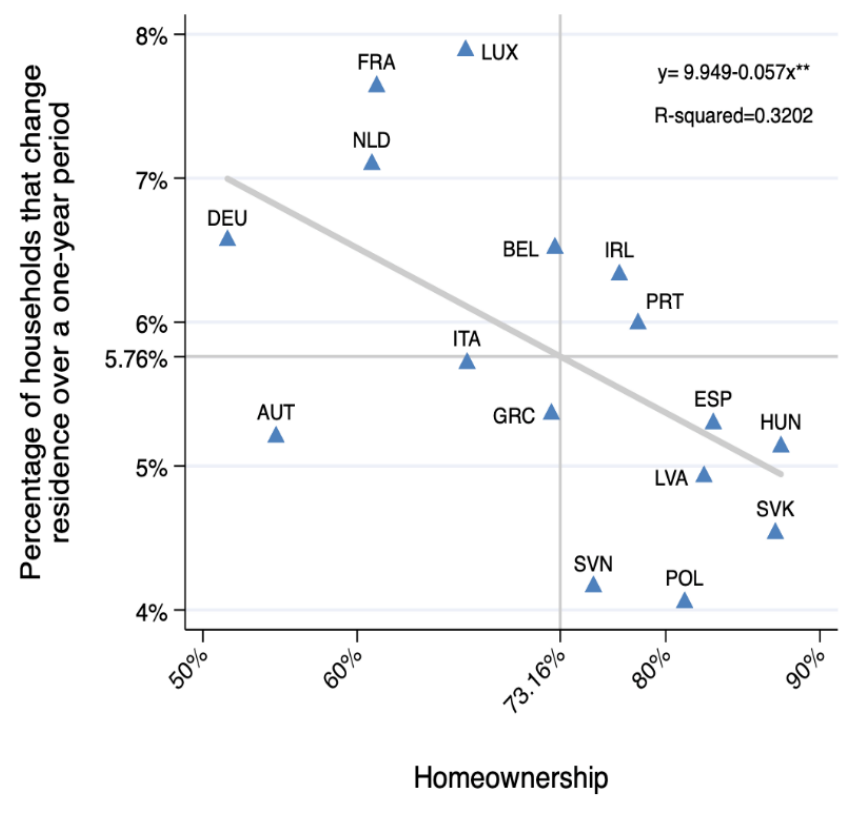

Note: Residential mobility is defined as the proportion of households that change their main residence over a one-year period. Restricted to age group 35-64.

Source: HFCS.

The negative association between homeownership and residential mobility directly reflects cross-country differences in the housing tenure mix to the extent that homeowners tend to be less mobile than private renters (Figure 31 ) ${ }^{33} \mathrm{~A}$ common conjecture is that mobility is lower among owner-occupiers than renters because owners face higher transaction costs of moving homes and therefore spend a longer time in their residence in order to spread the costs over a longer time period. Causation cannot be easily established and differences in mobility across tenure types could also reflect self-selection into various tenures. For example, some households may have a preference for stability and be more likely to choose owner occupancy. The negative association between homeownership and residential mobility can also reflect that when the tenure mix is skewed towards owner-occupancy, the size of the rental market and therefore turnover in the rental market is limited, which reduces mobility among renters. Indeed, the lowest level of mobility among renters is observed in high homeownership countries such as Eastern European countries, Portugal and Spain. One crude implication from the negative association between homeownership and residential mobility would be that there is trade-off between promoting homeownership and encouraging residential mobility.

${ }^{33}$ This finding is in line with previous papers (Caldera Sánchez and Andrews, 2011 $1_{[40]}$ ); see (Liu, 2018 [57]) and (World Bank, 2018 $\left.{ }_{[39]}\right)$ for more recent evidence. 
Figure 31. Owner-occupied households tend to be less mobile than renters

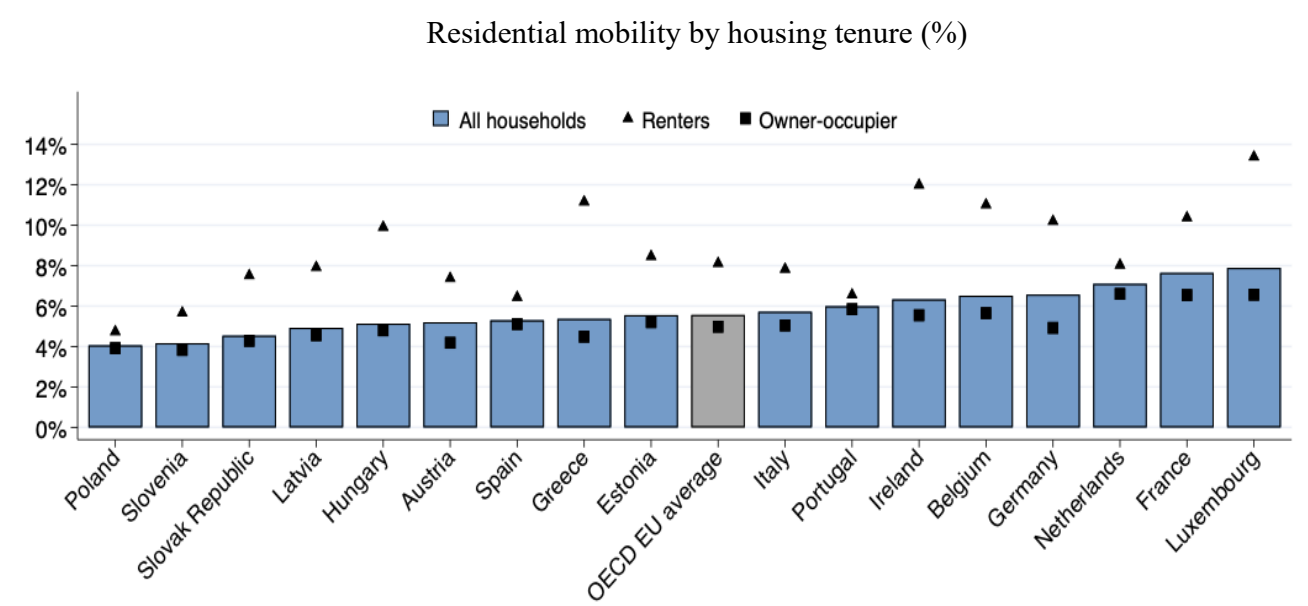

Note: Residential mobility is defined as the proportion of households that change their main residence over a one-year period. Restricted to age group 35-64.

Source: HFCS.

Reducing policy-driven residential mobility costs can help mitigating the trade-off between promoting homeownership and encouraging labour mobility. One relevant area is property transaction costs. For instance, stamp duties and registration taxes are typical transaction costs in buying and selling a property, together with real estate agent fees and legal fees, which are also influenced by government regulations. Data from Global Property Guide's in-house research published online ${ }^{34}$ and used in (World Bank, 2018 [39]) suggests that such transaction costs differ considerably across OECD countries: they are comparatively high in Belgium, France, Italy and Greece and comparatively low in the Nordic as well as AngloSaxon countries - in line with replies to the 2009 OECD questionnaire on housing. High transaction costs may discourage property transactions and thus curb the liquidity of housing markets, with potential negative repercussions for residential mobility. Empirical evidence has indeed shown that high transaction costs tend to reduce residential mobility (Caldera Sánchez and Andrews, 2011 ${ }_{[40]}$ ), (World Bank, 2018[39]).

The existing literature have suggested reforms to reduce transaction in two areas:

- Shifting from transfer taxes and stamp duties to (progressive) recurrent taxes on residential property. Reforms in this area are likely to make the housing market more liquid and efficient, but they could also make it more volatile and therefore less resilient. Governments need to seek an appropriate balance, taking into country-specific conditions since transaction taxes can be useful at curbing overheated housing markets.

- Liberalising professional services to reduce notarial, legal and real estate agency fees linked to housing transactions (see (Vitale, C. et al, 2019 $9_{[41]}$ )for recent indicators of product market regulations among notaries, lawyers and real estate agents). This can be achieved by reforming conveying procedures to allow for more competition among the providers of housing transaction services. For example, in

34 https://www.globalpropertyguide.com/home 
some countries the use of notaries is mandatory in real estate transactions. The case for reducing the role and cost of professional services in this area is all the more justified in a context of digitalisation that allow using new technologies (such as block chain) to secure property transactions.

Curbing excessively strict rental regulations can also increase residential and therefore labour mobility. Empirical evidence has shown that stricter rent controls and tenant landlord regulations significantly reduce residential mobility by discouraging the supply of

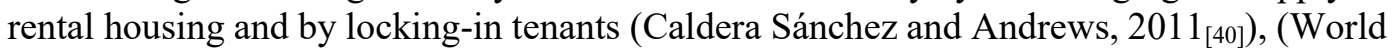
Bank, 2018[39] $)$. Recently-developed indexes of rental regulations suggest that rent control is comparatively strict in countries with a relatively large rental sector such as Denmark and Germany, possibly reflecting that in countries with large rental sectors the demand for regulation is greater. However, tenant-landlord regulation is measured as comparatively strict in both countries with large (e.g. Austria, France) and small (e.g. Italy, Spain) rental sectors (Figure 32). Reforms in the area of rental regulations need to strike a balance between landlords' and tenants' interest to create security of tenure and avoid market segmentation between sitting and new tenants (Andrews, Caldera Sánchez and Johansson, $\left.2011_{[11]}\right)$. On the one hand, absence of rent regulations can lead landlords to hold up tenants by unexpectedly raising rents. On the other hand, very strict rental regulations can hold up landlords' property and reduce incentives for investing in rental housing, maintenance and upkeep.

Figure 32. Excessive rental market regulation may hamper residential mobility

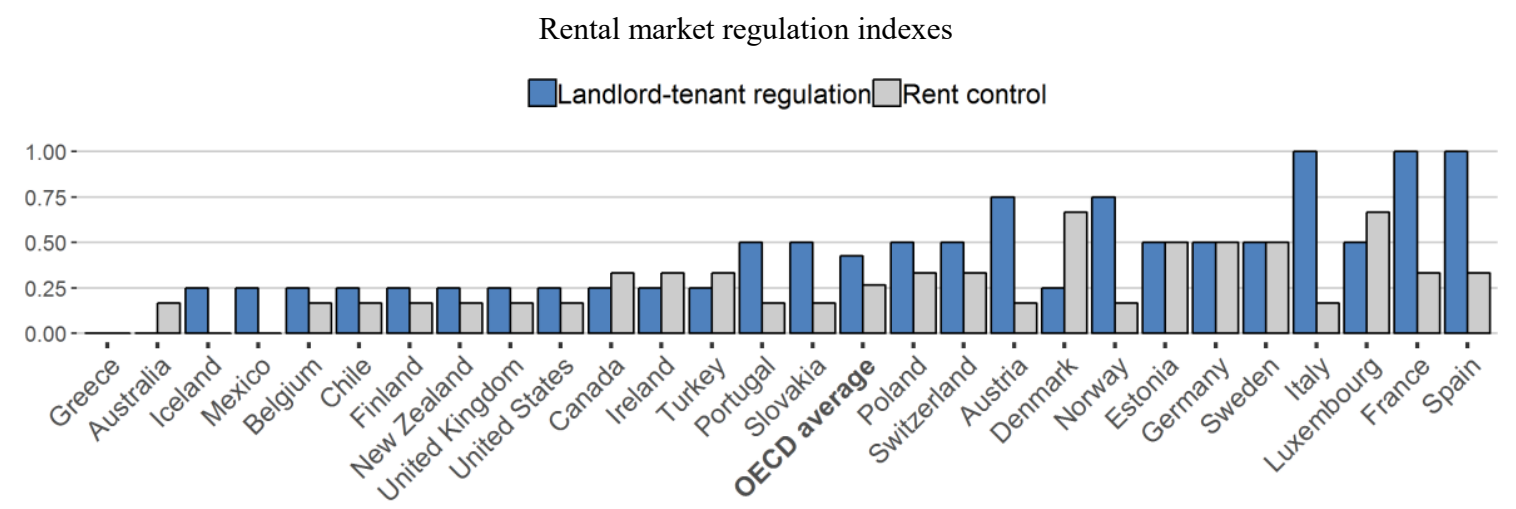

Note: The index varies between 0 and 1 and increases in the level of regulation (see (Kholodilin, 2018[42]) for details). Source: (Kholodilin, 2018[42]), Deutsches Institut für Wirtschaftsforschung (DIW).

Reforms to land-use regulations can influence housing supply and, in turn, residential mobility. In particular, where housing supply is more responsive to demand, residential mobility is higher (Caldera Sánchez and Andrews, 2011 $\left.1_{[40]}\right)$. This may reflect that higher supply responsiveness reduces housing affordability differentials and price gaps across regions, potentially easing relocation. In this context, policies to increase the responsiveness of housing supply are likely to deliver more efficient and inclusive housing markets: by curbing excessive house prices and making housing more affordable, by reducing geographical disparities and urban sprawl, and by encouraging residential mobility. Reforming land-use regulations and building restrictions is key in this respect, while balancing economic, social and environmental aspects. Security of property rights and better quality of land administration (e.g. coverage of registration system, reliability of 
administrative infrastructure, accessibility of information) have also been found to lead to higher residential mobility across European countries (World Bank, 2018 [39]).

Housing-related social transfers and subsidies aimed at addressing inclusiveness and redistributive concerns also influence residential mobility and require careful design to reconcile efficiency and equity objectives. Several studies have found that tenants in social housing are less mobile than private tenants, possibly reflecting the reluctance to give up their below-market rents and their generally more secure tenancies (Caldera Sánchez and Andrews, 2011 $1_{[40]}$ ), (World Bank, 2018 ${ }_{[39]}$ ). This has been found to be particularly the case in countries where social housing is highly targeted. However, the causality is unclear since households that are inherently less mobile to begin with - possibly due to unobserved characteristics such as cultural and or social attachment to their local area-may self-select into social housing.

Well-designed income-based portable housing allowances may be preferable to the direct provision of social housing as they do not seem to directly hinder residential mobility. ${ }^{35}$ Governments could also consider providing housing or rent subsidies for targeted groups, such as the young who are more likely to move, potentially making benefits conditional on job search responsibilities. Finally, experimenting with housing vouchers to encourage low-income households to move to higher income neighbourhood is another policy option to encourage residential and social mobility, as suggested by the "Moving to opportunity" program in the United States. That said, housing allowances have limitations as they cannot guarantee good housing and may perversely affect rent prices. They require careful design in terms of efficiency and targeting, that is, to avoid discouraging labour market participation, and to ensure take-up by households in greatest need for housing (World Bank, 2018[39]).

In this context, social housing is needed but should prevent residential segregation by ensuring that it is well integrated in the urban structure with appropriate access to transport sectors and public services (OECD, 2018 $\left.{ }_{[43]}\right)$. Urban transport planning policies are key complementary instruments and they should aim at desegregating and connecting people in disadvantaged communities. In addition, frequent reassessment of eligibility of social housing incumbent tenants with appropriate action if eligibility has changed is important as it frees up accommodation for needier households (Andrews, Caldera Sánchez and Johansson, 2011 $[11]$ ). Such reassessments may also help encouraging residential mobility, but they should be designed to avoid possible disincentives to labour market participation among incumbent tenants.

\subsection{Wrapping-up: a snapshot of countries' relative positions on housing and wealth distribution}

This paper has used a number of metrics to explore the links between housing and the distribution of wealth across households. The patterns described do not easily lead to straightforward conclusions, reflecting the high level of heterogeneity both within and across countries. As a way to summarise the material presented in the analysis, the conclusion presents a snapshot of countries' relative positions in the area of housing and wealth distribution.

\footnotetext{
${ }^{35}$ See (Whelan and Parkinson, $2017_{[80]}$ ) for a discussion and evidence on portable housing allowances in Australia.
} 
The snapshots cover indicators of homeownership and its distribution, wealth inequality, housing wealth concentration, mortgage indebtedness and residential mobility. It builds on three data sources: the OECD Wealth Distribution Database (WDD), the ECB Households Finance and Consumption Survey (HFCS) and the Luxembourg Wealth Survey (LWS). Methodological information about these data as well as reference years are provided in the Annex.

Table 1 and 2 present the result of this exercise, covering the indicators and their pairwise correlations. Figure 1 presents all country profiles, where indicators are normalised between 0 and 1 to enhance comparability across countries and indicators. For each country, the indicator is rescaled using a min-max normalisation that consists in rescaling the range of values to $[0,1]$ using the following formula:

$$
x^{\prime}=\frac{x-\min (x)}{\max (x)-\min (x)}
$$

Table 1 and Table 2 present the result of this tentative exercise, covering the indicators and their pairwise correlations. Figure 33 presents selected country profiles. The analysis leads to the following insights:

- High ownership countries tend to exhibit high ownership among low-income and young households. This pattern is associated with low wealth and housing wealth inequality, especially at the bottom of the distribution. Italy is a typical example.

- Countries characterised by high shares of households with mortgage debt tend to feature relatively high levels of wealth inequality at the bottom. This pattern is associated with a stronger prevalence of mortgage-related debt overburden. The Netherlands is a typical example.

- Residential mobility is low in countries featuring high ownership, especially among low-income households. Poland is a typical example. 
Table 1 Housing and wealth distribution outcomes (\%)

\begin{tabular}{|c|c|c|c|c|c|}
\hline Country & Homeownership & $\begin{array}{l}\text { Homeownership in } \\
\text { the } \\
\text { bottom income } \\
\text { quintile }\end{array}$ & $\begin{array}{l}\text { Homeownership in age } \\
\text { group }<34\end{array}$ & $\begin{array}{l}\text { Bottom } 40 \% \text { net } \\
\text { wealth share }\end{array}$ & $\begin{array}{c}\text { Bottom } 40 \% \text { net } \\
\text { housing wealth share }\end{array}$ \\
\hline AUS & $67.24 \%$ & $60.74 \%$ & $34.14 \%$ & $4.90 \%$ & $3.35 \%$ \\
\hline AUT & $47.66 \%$ & $24.72 \%$ & $19.07 \%$ & $1.01 \%$ & $-0.50 \%$ \\
\hline BEL & $70.32 \%$ & $44.33 \%$ & $57.60 \%$ & $5.68 \%$ & $7.45 \%$ \\
\hline CAN & $65.62 \%$ & $28.06 \%$ & $40.37 \%$ & $3.36 \%$ & $2.51 \%$ \\
\hline $\mathrm{CHL}$ & $61.91 \%$ & $63.32 \%$ & $39.89 \%$ & $0.06 \%$ & $0.34 \%$ \\
\hline DEU & $44.34 \%$ & $20.28 \%$ & $10.52 \%$ & $0.55 \%$ & $-0.26 \%$ \\
\hline DNK & $52.73 \%$ & $30.26 \%$ & $25.21 \%$ & $-8.65 \%$ & $-1.93 \%$ \\
\hline ESP & $83.12 \%$ & $73.00 \%$ & $68.36 \%$ & $6.91 \%$ & $10.38 \%$ \\
\hline EST & $76.47 \%$ & $62.04 \%$ & $47.55 \%$ & $3.77 \%$ & $4.51 \%$ \\
\hline FIN & $67.68 \%$ & $37.42 \%$ & $36.97 \%$ & $2.19 \%$ & $2.87 \%$ \\
\hline FRA & $58.74 \%$ & $32.96 \%$ & $28.37 \%$ & $2.69 \%$ & $2.27 \%$ \\
\hline GBR & $66.02 \%$ & $41.68 \%$ & $42.07 \%$ & $3.28 \%$ & $2.70 \%$ \\
\hline GRC & $72.07 \%$ & $64.62 \%$ & $28.30 \%$ & $5.25 \%$ & $6.83 \%$ \\
\hline HUN & $84.21 \%$ & $77.84 \%$ & $60.14 \%$ & $5.02 \%$ & $7.26 \%$ \\
\hline IRL & $70.49 \%$ & $60.17 \%$ & $29.71 \%$ & $-2.06 \%$ & $-7.25 \%$ \\
\hline ITA & $68.25 \%$ & $48.01 \%$ & $36.26 \%$ & $4.53 \%$ & $4.06 \%$ \\
\hline JPN & $76.47 \%$ & $66.05 \%$ & $26.61 \%$ & $5.29 \%$ & $2.20 \%$ \\
\hline LUX & $67.61 \%$ & $38.44 \%$ & $50.11 \%$ & $3.87 \%$ & $4.07 \%$ \\
\hline NLD & $55.60 \%$ & $15.45 \%$ & $34.87 \%$ & $-6.88 \%$ & $-18.45 \%$ \\
\hline NOR & $66.40 \%$ & $28.19 \%$ & $41.98 \%$ & $-3.00 \%$ & \\
\hline NZL & $65.00 \%$ & $52.45 \%$ & & $3.15 \%$ & $1.66 \%$ \\
\hline POL & $77.41 \%$ & $62.76 \%$ & $59.48 \%$ & $6.23 \%$ & $7.23 \%$ \\
\hline PRT & $74.71 \%$ & $60.57 \%$ & $54.35 \%$ & $3.17 \%$ & $4.35 \%$ \\
\hline SVK & $85.38 \%$ & $80.15 \%$ & $65.77 \%$ & $10.53 \%$ & $12.14 \%$ \\
\hline SVN & $73.73 \%$ & $64.34 \%$ & $39.40 \%$ & $5.62 \%$ & $7.57 \%$ \\
\hline USA & $63.73 \%$ & $36.90 \%$ & $33.46 \%$ & $-0.14 \%$ & $1.10 \%$ \\
\hline
\end{tabular}

Source: OECD Wealth Distribution Database, Household Finance and Consumption Survey (HFCS), Luxembourg Wealth Study (LWS). 
Table 1. Housing and wealth distribution outcomes (\%) (continued)

\begin{tabular}{|c|c|c|c|c|c|c|c|}
\hline Country & $\begin{array}{l}\text { Top } 10 \% \\
\text { net wealth } \\
\text { share }\end{array}$ & $\begin{array}{l}\text { Top } 10 \% \text { net } \\
\text { housing } \\
\text { wealth share }\end{array}$ & $\begin{array}{l}\text { Participation in the } \\
\text { mortgage market }\end{array}$ & $\begin{array}{l}\text { Participation in the } \\
\text { mortgage } \\
\text { market in the } \\
\text { bottom income } \\
\text { quintile }\end{array}$ & $\begin{array}{l}\text { Participation in } \\
\text { the mortgage } \\
\text { market in age } \\
\text { group<34 }\end{array}$ & $\begin{array}{l}\text { Mortgage- } \\
\text { overburdened } \\
\text { households }\end{array}$ & $\begin{array}{l}\text { Residential } \\
\text { mobility }\end{array}$ \\
\hline AUS & $46.48 \%$ & $33.52 \%$ & $32.16 \%$ & $9.89 \%$ & $29.96 \%$ & $18.84 \%$ & \\
\hline AUT & $55.66 \%$ & $40.15 \%$ & $15.50 \%$ & $5.03 \%$ & $11.97 \%$ & $8.91 \%$ & $4.07 \%$ \\
\hline BEL & $42.62 \%$ & $24.00 \%$ & $31.93 \%$ & $7.00 \%$ & $50.55 \%$ & $10.65 \%$ & $5.97 \%$ \\
\hline CAN & $51.09 \%$ & $38.23 \%$ & $37.62 \%$ & $12.01 \%$ & $37.56 \%$ & $23.12 \%$ & \\
\hline $\mathrm{CHL}$ & $57.77 \%$ & $46.92 \%$ & $16.48 \%$ & $7.01 \%$ & $15.22 \%$ & & \\
\hline DEU & $59.93 \%$ & $50.52 \%$ & $16.54 \%$ & $1.85 \%$ & $5.54 \%$ & $20.58 \%$ & $8.36 \%$ \\
\hline DNK & $63.98 \%$ & $47.16 \%$ & $38.09 \%$ & $15.25 \%$ & $16.71 \%$ & & \\
\hline ESP & $45.60 \%$ & $27.93 \%$ & $27.79 \%$ & $8.44 \%$ & $54.50 \%$ & $22.58 \%$ & $3.60 \%$ \\
\hline EST & $55.78 \%$ & $42.95 \%$ & $18.67 \%$ & $4.45 \%$ & $25.57 \%$ & $25.87 \%$ & $4.70 \%$ \\
\hline FIN & $45.24 \%$ & $30.83 \%$ & $32.83 \%$ & $4.41 \%$ & $33.54 \%$ & $21.82 \%$ & \\
\hline FRA & $50.82 \%$ & $33.27 \%$ & $18.97 \%$ & $4.89 \%$ & $23.29 \%$ & $20.46 \%$ & $7.55 \%$ \\
\hline GBR & $51.98 \%$ & $36.03 \%$ & $33.47 \%$ & $7.57 \%$ & $40.17 \%$ & $22.26 \%$ & \\
\hline GRC & $42.52 \%$ & $27.92 \%$ & $11.42 \%$ & $6.65 \%$ & $4.35 \%$ & $27.37 \%$ & $4.02 \%$ \\
\hline HUN & $48.53 \%$ & $33.31 \%$ & $18.76 \%$ & $10.95 \%$ & $21.19 \%$ & $22.34 \%$ & $5.83 \%$ \\
\hline IRL & $53.80 \%$ & $28.81 \%$ & $33.87 \%$ & $11.93 \%$ & $26.15 \%$ & $48.99 \%$ & \\
\hline ITA & $43.02 \%$ & $33.00 \%$ & $9.62 \%$ & $1.93 \%$ & $16.52 \%$ & $12.11 \%$ & $4.82 \%$ \\
\hline JPN & $41.02 \%$ & $38.76 \%$ & $22.36 \%$ & $3.35 \%$ & $19.33 \%$ & & \\
\hline LUX & $48.80 \%$ & $26.00 \%$ & $29.07 \%$ & $9.60 \%$ & $34.22 \%$ & $13.11 \%$ & $7.91 \%$ \\
\hline NLD & $68.35 \%$ & $55.87 \%$ & $48.10 \%$ & $10.39 \%$ & $34.30 \%$ & $38.35 \%$ & $6.64 \%$ \\
\hline NOR & $51.45 \%$ & & & & & & \\
\hline NZL & $52.90 \%$ & $23.75 \%$ & $28.77 \%$ & $10.02 \%$ & $23.43 \%$ & & \\
\hline POL & $41.98 \%$ & $33.46 \%$ & $12.00 \%$ & $2.46 \%$ & $20.60 \%$ & $17.94 \%$ & $3.01 \%$ \\
\hline PRT & $52.19 \%$ & $25.88 \%$ & $32.66 \%$ & $11.11 \%$ & $45.10 \%$ & $34.68 \%$ & $2.45 \%$ \\
\hline SVK & $34.74 \%$ & $25.89 \%$ & $15.18 \%$ & $3.57 \%$ & $32.60 \%$ & $16.44 \%$ & $3.14 \%$ \\
\hline SVN & $48.76 \%$ & $28.10 \%$ & $8.16 \%$ & $0.91 \%$ & $9.81 \%$ & $16.02 \%$ & $3.05 \%$ \\
\hline USA & $79.47 \%$ & $49.90 \%$ & $42.22 \%$ & $15.08 \%$ & $29.23 \%$ & $27.50 \%$ & \\
\hline
\end{tabular}

Source: OECD Wealth Distribution Database, Household Finance and Consumption Survey (HFCS), Luxembourg Wealth Study (LWS). 
Table 2 Housing and wealth distribution outcomes pairwise correlations

\begin{tabular}{|c|c|c|c|c|c|c|c|c|c|c|c|}
\hline & $\begin{array}{l}\text { Home- } \\
\text { ownership }\end{array}$ & $\begin{array}{l}\text { Homeownership } \\
\text { in the } \\
\text { bottom income } \\
\text { quintile }\end{array}$ & $\begin{array}{c}\text { Homeownership in } \\
\text { age group }<34\end{array}$ & $\begin{array}{l}\text { Bottom } \\
40 \% \text { net } \\
\text { wealth } \\
\text { share }\end{array}$ & $\begin{array}{l}\text { Bottom } \\
40 \% \text { net } \\
\text { housing } \\
\text { wealth } \\
\text { share }\end{array}$ & $\begin{array}{l}\text { Top 10\% } \\
\text { net } \\
\text { wealth } \\
\text { share }\end{array}$ & $\begin{array}{l}\text { Top 10\% } \\
\text { net } \\
\text { housing } \\
\text { wealth } \\
\text { share }\end{array}$ & $\begin{array}{l}\text { Participation in } \\
\text { the mortgage } \\
\text { market }\end{array}$ & $\begin{array}{l}\text { Participation in } \\
\text { the mortgage } \\
\text { market in the } \\
\text { bottom income } \\
\text { quintile }\end{array}$ & $\begin{array}{l}\text { Participation } \\
\text { in the } \\
\text { mortgage } \\
\text { market in age } \\
\text { group }<34\end{array}$ & $\begin{array}{l}\text { Mortgage- } \\
\text { overburdened } \\
\text { households }\end{array}$ \\
\hline $\begin{array}{l}\text { Homeownership } \\
\text { bottom income } \\
\text { quintile }\end{array}$ & $0.85^{\star \star \star}$ & & & & & & & & & & \\
\hline $\begin{array}{l}\text { Homeownership in } \\
\text { age group<34 }\end{array}$ & $0.80^{* * *}$ & $0.58^{* *}$ & & & & & & & & & \\
\hline $\begin{array}{l}\text { Bottom } 40 \% \text { net } \\
\text { wealth share }\end{array}$ & $0.68^{* * *}$ & $0.67^{\star * *}$ & $0.54^{* *}$ & & & & & & & & \\
\hline $\begin{array}{l}\text { Bottom } 40 \% \text { net } \\
\text { housing wealth } \\
\text { share }\end{array}$ & $0.63^{* * *}$ & $0.62^{\star \star \star}$ & $0.56^{\star *}$ & $0.85^{\star * *}$ & & & & & & & \\
\hline $\begin{array}{l}\text { Top 10\% net } \\
\text { wealth share }\end{array}$ & $-0.61^{\text {** }}$ & $-0.56^{\star *}$ & $-0.43^{*}$ & $-0.75^{\star * *}$ & $-0.65^{\star \star *}$ & & & & & & \\
\hline $\begin{array}{l}\text { Top 10\% net } \\
\text { housing wealth } \\
\text { share }\end{array}$ & $-0.60^{* *}$ & $-0.53^{\star *}$ & $-0.53^{* *}$ & $-0.68^{* * *}$ & $-0.63^{* * *}$ & $0.75^{\star \star *}$ & & & & & \\
\hline $\begin{array}{l}\text { Participation in the } \\
\text { mortgage market }\end{array}$ & -0.22 & $-0.45^{\star}$ & -0.03 & $-0.55^{\star *}$ & $-0.55^{\star *}$ & $0.53^{\star *}$ & 0.26 & & & & \\
\hline $\begin{array}{l}\text { Participation in the } \\
\text { mortgage } \\
\text { market bottom } \\
\text { income quintile }\end{array}$ & -0.11 & -0.17 & 0.04 & $-0.52^{* *}$ & -0.35 & $0.55^{* *}$ & 0.16 & $0.78^{\star \star *}$ & & & \\
\hline $\begin{array}{l}\text { Participation in the } \\
\text { mortgage } \\
\text { market in age } \\
\text { group }<34\end{array}$ & 0.36 & 0.05 & $0.64^{\star * *}$ & 0.18 & 0.11 & -0.10 & -0.30 & $0.60^{\star *}$ & 0.36 & & \\
\hline $\begin{array}{l}\text { Mortgage } \\
\text { overburdened } \\
\text { households }\end{array}$ & 0.05 & 0.04 & -0.12 & $-0.59^{* *}$ & $-0.58^{* *}$ & 0.42 & 0.22 & $0.50^{*}$ & $0.54^{*}$ & 0.12 & \\
\hline Residential mobility & $-0.58^{*}$ & $-0.67^{\star \star}$ & -0.44 & -0.49 & -0.45 & 0.45 & 0.43 & 0.30 & 0.13 & -0.10 & -0.06 \\
\hline
\end{tabular}

Source: OECD Wealth Distribution Database, Household Finance and Consumption Survey (HFCS), Luxembourg Wealth Study (LWS). 
Figure 33: A snapshot of countries' relative positions on housing and wealth (normalised indicators): selected countries

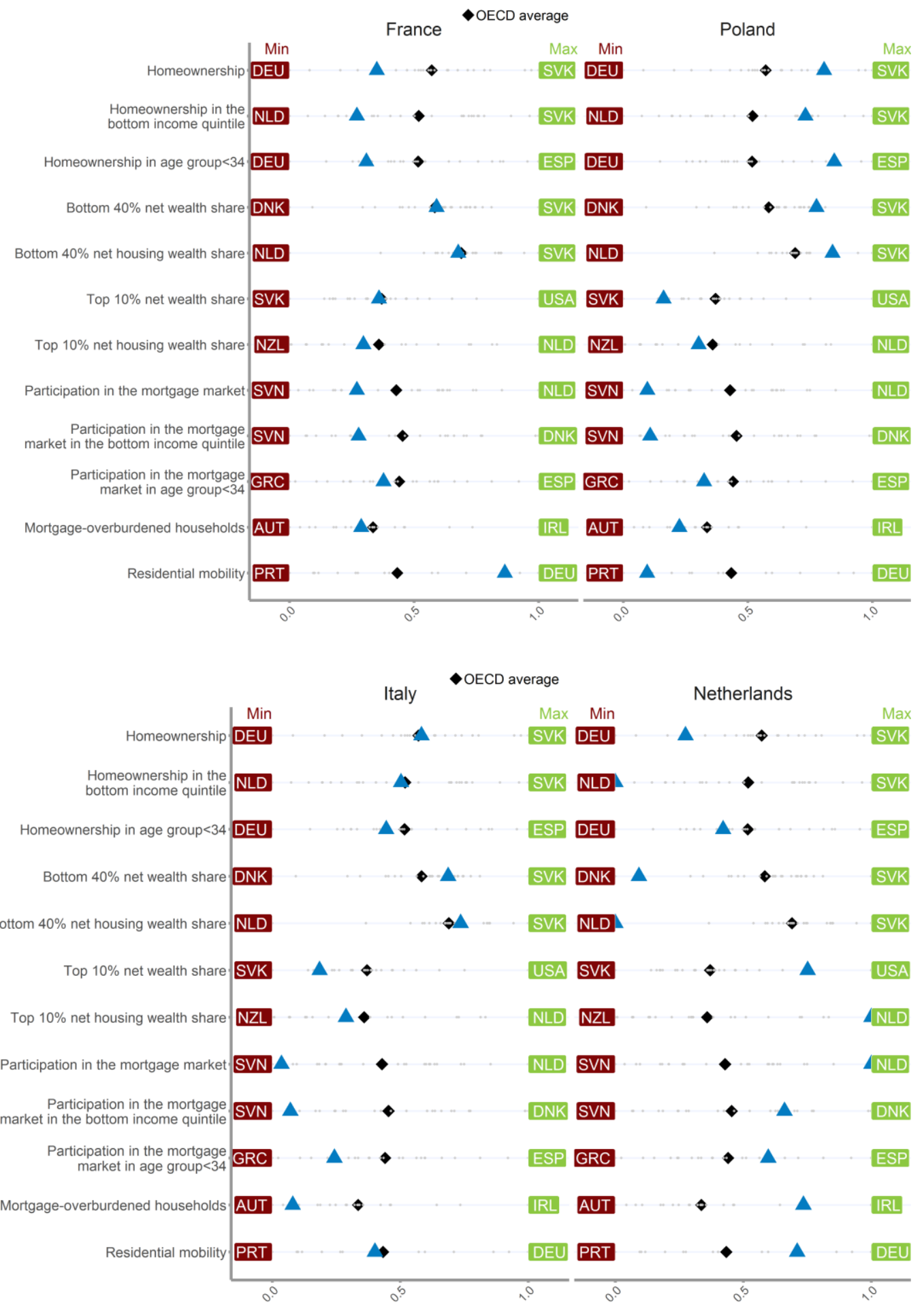

Note: See annex for specific definitions of indicators.

Source: Authors' calculations based on OECD Wealth Distribution database, HFCN and LWS. 


\begin{abstract}
ANNEX
This annex provides additional material on housing and the wealth distribution. It is structured in four parts. Section A complements the conceptual and data section with datarelated information and associated methodological issues. Section B delivers preliminary evidence on housing and wealth inequality over time. Section $\mathrm{C}$ details the microeconometric approach and results of wealth regressions.
\end{abstract}

Annex A 2.1.1 Housing from a wealth distribution perspective: additional details on data and measurement

The paper relies on three data sources that have different levels of granularity and coverage. The ECB Household Finance and Consumption Survey (HFCS) and the Luxembourg Wealth Studies (LWS) are both microdata sources with limited country coverage, while the OECD Wealth Distribution Database (WDD) provides semi-aggregated data for a larger number of countries. Table 3 provides detailed information about year and country coverage of each data source used throughout the paper. 
Table 3. Data coverage and sources

\begin{tabular}{|c|c|c|c|c|c|c|}
\hline & 2011 & 2012 & 2013 & 2014 & 2015 & 2016 \\
\hline Australia & & & & LWS/WDD & & \\
\hline Austria & & & & HFCS/WDD & & \\
\hline Belgium & & & & HFCS/WDD & & \\
\hline Canada & & LWS & & & & WDD \\
\hline Chile & & & & WDD & & \\
\hline Denmark & & & & & WDD & \\
\hline Estonia & & & HFCS/WDD & & & \\
\hline Finland & & & & HFCS/WDD & & \\
\hline France & & & & HFCS/WDD & & \\
\hline Germany & & & & HFCS/WDD & & \\
\hline Greece & & & & HFCS/WDD & & \\
\hline Hungary & & & & HFCS/WDD & & \\
\hline Ireland & & & HFCS/WDD & & & \\
\hline Italy & & & & HFCS/WDD & & \\
\hline Japan & & & & WDD & & \\
\hline Korea & & & & & WDD & \\
\hline Latvia & & & & HFCS/WDD & & \\
\hline Luxembourg & & & & HFCS/WDD & & \\
\hline Netherlands & & & HFCS & & WDD & \\
\hline New Zealand & & & & WDD & & \\
\hline Norway & & & LWS & WDD & & \\
\hline Poland & & & & HFCS/WDD & & \\
\hline Portugal & & & HFCS/WDD & & & \\
\hline Slovak Republic & & & & HFCS/WDD & & \\
\hline Slovenia & & & & HFCS/WDD & & \\
\hline Spain & HFCS/WDD & & & & & \\
\hline United Kingdom & LWS & & & & WDD & \\
\hline United States & & & & & & LWS \\
\hline
\end{tabular}

Note: HFCS refers to the ECB Household Finance and Consumption Survey, LWS to the Luxembourg Wealth Studies and WDD to the OECD Wealth Distribution Database. All three datasets include earlier data that is not used in the paper.

Additional details on the micro-sources used in the paper: HFCS and LWS ${ }^{36}$

Table 4 delivers detailed information about the HFCS database, emphasizing countryspecific methodological features.

${ }^{36}$ See Box 1 for a description of the WDD dataset. 
Table 4. Country-specific methodological features of HFCS survey

\begin{tabular}{|c|c|c|c|c|c|c|}
\hline \multirow[b]{2}{*}{ Country } & \multicolumn{6}{|c|}{ Sampling } \\
\hline & $\begin{array}{l}\text { Probability } \\
\text { sample }\end{array}$ & $\begin{array}{l}\text { Stratified } \\
\text { sample }\end{array}$ & $\begin{array}{l}\text { Over-sampling the } \\
\text { wealthy }\end{array}$ & $\begin{array}{l}\text { Survey has a } \\
\text { panel } \\
\text { component }^{2}\end{array}$ & Total number of sampling stages & $\begin{array}{l}\text { Substitutions } \\
\text { allowed }\end{array}$ \\
\hline Belgium & $\mathrm{x}$ & $x$ & Regional & $\mathrm{x}$ & 1 & \\
\hline Germany & $x$ & $x$ & Regional & $x$ & 3 & \\
\hline Estonia & $x$ & $x$ & Yes & & 1 & \\
\hline Ireland & $x$ & $x$ & Regional & & 2 & \\
\hline Greece & $x$ & $x$ & Regional & & 2 & \\
\hline Spain & $x$ & $x$ & Yes & $x$ & 1 for municipalities with $>100,000$ inhabitants, 2 for the rest & $x$ \\
\hline France & $x$ & $x$ & Yes & $x$ & 2 & \\
\hline Italy & $x$ & $x$ & & $x$ & 2 & $x$ \\
\hline Cyprus & $x$ & $x$ & Yes & $x$ & 1 for municipalities with $>40,000$ inhabitants, 2 for the rest & $x$ \\
\hline Latvia & $x$ & $x$ & Yes & & 2 & \\
\hline Luxembourg & $x$ & $x$ & Yes & & 1 & \\
\hline Hungary & $x$ & $x$ & Regional & & 2 & \\
\hline Malta & $x$ & & & $x$ & 1 & \\
\hline Netherlands & $x$ & & & $\mathrm{x}$ & 1 & \\
\hline Austria & $x$ & $x$ & & & 2 & \\
\hline Poland & $\mathrm{x}$ & $x$ & Regional & & 2 & \\
\hline Portugal & $x$ & $x$ & Yes & & 2 & \\
\hline Slovenia & $x$ & $x$ & & & 2 & \\
\hline Slovakia & $x$ & $x$ & Regional & & 2 & \\
\hline Finland & $x$ & $\mathrm{x}$ & Yes & $x$ & 1 & \\
\hline
\end{tabular}

A feature of HFCS data is the use of multiple imputations for each country except Finland, Ireland and Italy ${ }^{37}$. The objective is to cover for item non-response via stochastic imputation. This means estimating missing observations conditional upon observed variables that can plausibly explain the missing values. For each missing value, five imputed values are provided (thus giving rise to five complete data sets). The reason why missing values are multiply imputed is that if only a single imputation is done, this would not take into account imputation uncertainty. Multiple imputation allows users to make straightforward estimates of the degree of uncertainty associated with the missing information using Rubin's law (Rubin, $1987_{[44]}$ ). The mean of any given statistic $X$ is given by the mean of its estimates across all five replicates:

$$
\bar{X}=\frac{1}{5} \sum_{i=1}^{5} \bar{X}_{i}
$$

Its variance is given by a weighted average of a within and a between component. The within component $\mathrm{W}$ is equal to the mean of the estimates of $\operatorname{Var}(X)$ obtained on each replicate:

$$
\mathrm{W}=\frac{1}{5} \sum_{i=1}^{5} \hat{V}_{i}
$$

The between component provides information on the imputation uncertainty as it measures the variance of the point estimate across replicates:

$$
\mathrm{B}=\sum_{i=1}^{5}\left(\bar{X}_{i}-\bar{X}\right)
$$

Total variance derives from these two components:

\footnotetext{
${ }^{37}$ Multiple imputation is also used for the United States in LWS.
} 


$$
T=W+\frac{6}{5} \mathrm{~B}
$$

The statistical and econometric analysis presented in the paper takes into account multiple imputations according to the equations above.

Table 5 provides detailed information about the LWS datasets. One major limitation of LWS is that the microdata cannot be accessed directly but only through remote access, which reduces the scope of possible statistical and econometric analysis.

Table 5. Methodological information on LWS data

\begin{tabular}{|c|c|c|c|c|c|c|}
\hline & $\begin{array}{l}\text { Name of } \\
\text { survey }\end{array}$ & $\begin{array}{l}\text { Responsible } \\
\text { institution }\end{array}$ & $\begin{array}{l}\text { Survey } \\
\text { year I } \\
\text { Wave }\end{array}$ & Sample size & $\begin{array}{l}\text { Item non-response / } \\
\text { imputation }\end{array}$ & Weighting \\
\hline $\begin{array}{c}\text { Australia } \\
(2014)\end{array}$ & $\begin{array}{l}\text { Survey of } \\
\text { Income and } \\
\text { Housing } \\
\text { (SIH) }\end{array}$ & $\begin{array}{c}\text { Australian } \\
\text { Bureau of } \\
\text { Statistics (ABS) }\end{array}$ & $\begin{array}{c}2013- \\
2014 \\
\text { survey. }\end{array}$ & $\begin{array}{c}14,162 \text { households including } \\
27,265 \text { adults. }\end{array}$ & $\begin{array}{l}\text { Imputation took place for } \\
\text { missing records and } \\
\text { values. } \\
\text { In addition, several data } \\
\text { items were modelled by } \\
\text { ABS on the basis of } \\
\text { information provided by } \\
\text { the respondents. }\end{array}$ & $\begin{array}{l}\text { Final weights are } \\
\text { calculated through an } \\
\text { iterative procedure. }\end{array}$ \\
\hline $\begin{array}{l}\text { Canada } \\
(2016)\end{array}$ & $\begin{array}{l}\text { Survey of } \\
\text { Financial } \\
\text { Securities } \\
\text { (SFS) }\end{array}$ & $\begin{array}{l}\text { Statistics } \\
\text { Canada }\end{array}$ & $\begin{array}{c}2016 \\
\text { survey. }\end{array}$ & $\begin{array}{l}\text { The overall initial sample size } \\
\text { was } 21,112 \text { dwellings. The } \\
\text { public use microdata file } \\
\text { (PUMF) contains } 12,429 \\
\text { family units. }\end{array}$ & $\begin{array}{l}\text { In SCF } 2016 \text { missing } \\
\text { values for the income, } \\
\text { assets, and debts } \\
\text { variables have been } \\
\text { entirely imputed (income } \\
\text { figures are imputed only in } \\
\text { the absence of tax data). } \\
\text { The nearest-neighbour } \\
\text { imputation method was } \\
\text { used primarily. }\end{array}$ & $\begin{array}{l}\text { Design weights for SFS } \\
\text { are determined } \\
\text { separately for the } \\
\text { samples selected from } \\
\text { the two frames. }\end{array}$ \\
\hline $\begin{array}{l}\text { Norway } \\
(2013)\end{array}$ & $\begin{array}{l}\text { Household } \\
\text { Wealth } \\
\text { Statistics }\end{array}$ & $\begin{array}{l}\text { Statsitics } \\
\text { Norway / } \\
\text { Statistisk } \\
\text { sentralbyrå } \\
\text { (SSB) }\end{array}$ & 2013 & $\begin{array}{c}\text { Not applicable (census data). } \\
\text { Note: the } 10 \% \text { extraction for } \\
\text { LIS includes } 235,732 \\
\text { households. }\end{array}$ & $\begin{array}{l}\text { Not applicable (fully } \\
\text { register-based data). }\end{array}$ & $\begin{array}{l}\text { Not applicable (census } \\
\text { data). } \\
\text { Note: the } 10 \% \text { extraction } \\
\text { used for the LIS file is a } \\
\text { self-weighted sample. }\end{array}$ \\
\hline $\begin{array}{l}\text { United } \\
\text { Kingdom } \\
(2009)\end{array}$ & $\begin{array}{l}\text { Wealth and } \\
\text { Assets } \\
\text { Survey } \\
\text { (WAS) }\end{array}$ & $\begin{array}{l}\text { Office of } \\
\text { National } \\
\text { Statistics } \\
\text { (ONS) }\end{array}$ & $\begin{array}{c}2008- \\
2010 \\
\text { Wave } 2 .\end{array}$ & 20,165 households. & $\begin{array}{l}\text { Single imputation was } \\
\text { applied across all of the } \\
\text { variables that formed the } \\
\text { building blocks for key } \\
\text { outputs. }\end{array}$ & $\begin{array}{l}\text { Cross-sectional } \\
\text { calibration weight and } \\
\text { individual longitudinal } \\
\text { weight are available, no } \\
\text { replicate weights. }\end{array}$ \\
\hline $\begin{array}{l}\text { United } \\
\text { States } \\
(2016)\end{array}$ & $\begin{array}{l}\text { Survey of } \\
\text { Consumer } \\
\text { Finances } \\
\text { (SCF) }\end{array}$ & $\begin{array}{l}\text { Board of } \\
\text { Governors of } \\
\text { the Federal } \\
\text { Reserve } \\
\text { System }\end{array}$ & $\begin{array}{c}2016 \\
\text { survey. }\end{array}$ & $\begin{array}{l}6,254 \text { families were } \\
\text { interviewed. The public } \\
\text { version of the data set } \\
\text { contains } 6,248 \text { of the } 6,254 \\
\text { observations in the full data } \\
\text { set ( } 6 \text { observations had net } \\
\text { worth at least equal to the } \\
\text { minimum level needed to } \\
\text { qualify for the Forbes list, thus } \\
\text { they were removed from } \\
\text { public data set). }\end{array}$ & $\begin{array}{l}\text { Most of the variables that } \\
\text { originally contained a } \\
\text { missing value code have } \\
\text { been imputed. A multiple } \\
\text { imputation procedure } \\
\text { yielding five values for } \\
\text { each missing value is used } \\
\text { to approximate the } \\
\text { distribution of the missing } \\
\text { data. }\end{array}$ & $\begin{array}{l}\text { Final non-response- } \\
\text { adjusted sampling } \\
\text { weights are intended to } \\
\text { compensate for unequal } \\
\text { probabilities of selection } \\
\text { in the original design } \\
\text { and for unit } \\
\text { nonresponse (failure to } \\
\text { obtain an interview) }\end{array}$ \\
\hline
\end{tabular}

Source: www.lisdatacenter.org. 


\section{A technical note on the use of semi-aggregated data for analysing household wealth and its distribution}

The WDD provides a consistent, high-quality and comparable set of semi-aggregated data on household wealth with a large country coverage. However, not all statistics on household wealth and its distribution can be correctly calculated with semi-aggregated data, which is why the analysis presented in the paper switches to microdata in a number of cases. This section sheds light on this issue.

One statistic presented in the paper is the share of housing in total household wealth. Based on semi-aggregated data, one could divide the total value of housing assets by the total value of all assets in the country, i.e. the "ratio of means": mean housing wealth over mean total wealth. This statistic does not measure the share of housing in total wealth for the average household. Due to the non-transitivity of the divide operator, the "ratio of means" is different from the "mean of ratios", i.e. the average across all households of the ratio of housing assets over total wealth.

Let $M o R$ be the mean of ratios. Using microdata, one can compute the share of housing in total wealth for each household and average across all the households in the population:

$$
M o R=\frac{1}{N} \sum \frac{\text { Housing }_{i}}{\text { Assets }_{i}}
$$

Let $R o M$ be the ratio of means. Using semi-aggregated data, one can compute the sum of housing assets and divide by the sum of total assets:

$$
R o M=\frac{\text { mean }\left(\text { Housing }_{i}\right)}{\operatorname{mean}\left(\text { Assets }_{i}\right)}=\frac{\operatorname{sum}\left(\text { Housing }_{i}\right)}{\operatorname{sum}\left(\text { Assets }_{i}\right)}
$$

2. The ratio of means (RoM) can be rewritten as follows:

$$
\text { RoM }=\frac{\sum \text { Housing }_{i}}{\sum \text { Assets }_{i}}=\sum \frac{\text { Housing }_{i}}{\text { Assets }_{i}} * \frac{\text { Assets }_{i}}{\sum \text { Assets }_{i}}
$$

The first term $\left(\frac{\text { Housing }_{i}}{\text { Assets }_{i}}\right)$ corresponds to the share of housing over total assets for household $i$, also to be found in the definition of the MoR. The second term $\left(\frac{\text { Assets }_{i}}{\sum \text { Assets }_{i}}\right)$ is equal to household 's assets divided by the sum of all households' assets. It is a weighting factor which increases with the share of household $i$ in the nationwide distribution of assets. As a result, whereas the $M o R$ is an average that gives each households the same weight $\left(\frac{1}{N}\right)$, the RoM gives greater weight to wealthier households $\left(\frac{\text { Assets }_{i}}{\sum \text { Assets }_{i}}\right)$. The MoR measures the share of housing in total wealth from the perspective of the average household within a country. This statistic can only be computed with microdata, as done in e.g. Figure 8 of the paper.

\section{Main concepts and descriptive statistics ${ }^{38}$}

Net wealth is defined as the difference between total (gross) assets and total liabilities. Total assets consist of real assets including the value of the households main residence (HMR) and

\footnotetext{
${ }^{38}$ There are conceptual differences between the WDD and HFCS nomenclatures. For instance, in the HFCS self-employment businesses are under real assets, while they are considered as financial wealth in the WDD. For more detail on the WDD nomenclature, see the following link: http://stats.oecd.org/wbos/fileview2.aspx?IDFile=c8a13487-8e30-4629-9045-74e2a6aa060b.
} 
value of other real estate property as well as financial assets. Real assets include value of the household main residence (HMR), value of other real estate property, value of vehicles, value of valuables of household members. Financial assets include deposits (sight accounts, savings accounts), investment in mutual funds, bonds, investment in non-self-employment private businesses, value of self-employment businesses, publicly traded shares, managed investment accounts, money owed to household as private loans, other financial assets (e.g. options, index certificates), private pension plans and whole life insurance policies. Total liabilities consist of outstanding amount of HMR mortgages, outstanding amount on other real estate mortgages, outstanding amount of debt on credit cards and credit lines/bank overdraft, outstanding amount of other, non-collateralised loans. Net housing wealth is correspondingly defined as the current market value of the HMR net of the outstanding amount of HMR mortgages. The analysis in the paper relied on gross income for HFCS countries (except Finland and Italy) and disposable income for other countries covered in the WDD. Gross income includes labour income, capital income and transfers, but does not exclude taxes. Disposable income is equal to gross income minus taxes. Table 6 provides descriptive statistics for these quantities. 
Table 6. Descriptive statistics

\begin{tabular}{|c|c|c|c|c|c|c|c|c|}
\hline Country & $\begin{array}{c}\text { Mean } \\
\text { household } \\
\text { net wealth } \\
\text { (NW) }\end{array}$ & $\begin{array}{l}\text { Median } \\
\text { household } \\
\text { net wealth } \\
\text { (NW) }\end{array}$ & $\begin{array}{c}\text { Mean } \\
\text { household } \\
\text { gross income }\end{array}$ & $\begin{array}{l}\text { Total non- } \\
\text { financial } \\
\text { assets }\end{array}$ & $\begin{array}{c}\text { Total } \\
\text { financial } \\
\text { assets }\end{array}$ & $\begin{array}{c}\text { Total } \\
\text { liabilities }\end{array}$ & $\begin{array}{l}\text { Housing } \\
\text { wealth }\end{array}$ & $\begin{array}{c}\text { Principal } \\
\text { residence } \\
\text { debt }\end{array}$ \\
\hline Australia & 649,993 & 380,000 & 107,557 & 630,852 & 164,058 & 144,916 & 399,313 & 81,645 \\
\hline Austria & 258,414 & 85,914 & 43,334 & 189,042 & 86,615 & 17,243 & 137,576 & 13,790 \\
\hline Belgium & 330,266 & 217,943 & 51,957 & 255,722 & 114,249 & 39,704 & 190,105 & 30,464 \\
\hline Canada & 574,500 & 258,100 & 106,900 & 430,000 & 244,500 & 100,000 & 301,100 & 77,600 \\
\hline Chile & $42,427,004$ & $17,747,804$ & $1,414,313$ & $45,975,084$ & $4,224,361$ & $7,772,443$ & $32,218,394$ & $4,537,672$ \\
\hline Denmark & 996,949 & 212,967 & 455,775 & $1,416,793$ & 463,113 & 854,025 & $1,059,753$ & 527,346 \\
\hline Estonia & 96,994 & 43,474 & 17,095 & 76,201 & 29,411 & 8,618 & 52,881 & 7,282 \\
\hline Finland & 195,328 & 110,000 & 50,062 & 187,257 & 51,573 & 43,458 & 126,898 & 30,177 \\
\hline France & 243,130 & 113,300 & 37,552 & 192,753 & 85,846 & 33,138 & 126,193 & 18,290 \\
\hline Germany & 214,259 & 60,790 & 48,399 & 157,993 & 82,000 & 25,734 & 102,617 & 16,127 \\
\hline Greece & 104,199 & 65,058 & 21,213 & 96,995 & 14,760 & 7,556 & 59,131 & 5,098 \\
\hline Hungary & $15,553,559$ & $8,018,422$ & $3,300,047$ & $12,484,595$ & $4,502,902$ & $1,428,429$ & $9,534,387$ & 942,083 \\
\hline Ireland & 216,349 & 100,600 & 54,645 & 235,989 & 51,293 & 70,934 & 133,869 & 50,759 \\
\hline Italy & 226,389 & 146,198 & 33,374 & 193,066 & 43,238 & 9,916 & 146,854 & 7,658 \\
\hline Japan & $32,555,000$ & $20,147,000$ & $5,371,000$ & $22,082,000$ & $14,583,000$ & $4,111,000$ & $17,493,000$ & $3,518,000$ \\
\hline Korea & $284,289,984$ & $164,840,000$ & $47,700,000$ & $253,960,000$ & $92,900,000$ & $62,560,000$ & $131,660,000$ & $16,000,000$ \\
\hline Latvia & 40,044 & 14,180 & 14,240 & 36,947 & 10,600 & 7,503 & 23,003 & 4,682 \\
\hline Luxembourg & 768,404 & 437,510 & 87,199 & 698,910 & 166,809 & 97,316 & 438,017 & 66,742 \\
\hline Netherlands & 140,500 & 17,300 & & 163,700 & 82,500 & 105,700 & 138,400 & 90,700 \\
\hline New Zealand & 630,859 & 289,000 & 97,151 & 367,462 & 353,225 & 89,829 & 215,930 & 57,188 \\
\hline Norway & $2,272,944$ & $1,163,457$ & 764,398 & $2,516,776$ & $1,013,656$ & $1,257,486$ & $2,109,448$ & \\
\hline Poland & 403,392 & 238,885 & 70,413 & 340,109 & 84,626 & 21,343 & 283,119 & 16,937 \\
\hline Portugal & 155,956 & 71,215 & 21,546 & 137,590 & 47,182 & 28,814 & 80,965 & 23,753 \\
\hline Slovak Republic & 66,047 & 50,316 & 15,425 & 61,596 & 9,847 & 5,391 & 51,158 & 4,001 \\
\hline Slovenia & 137,718 & 80,367 & 19,841 & 103,822 & 40,494 & 6,597 & 78,007 & 3,793 \\
\hline Spain & 273,579 & 159,639 & 31,856 & 238,283 & 70,152 & 34,857 & 153,450 & 22,612 \\
\hline United Kingdom & 435,500 & 183,000 & 43,700 & 267,600 & 215,600 & 47,600 & 185,100 & 35,400 \\
\hline United States & 632,100 & 77,400 & 99,400 & 302,600 & 434,100 & 102,900 & 191,900 & 66,400 \\
\hline
\end{tabular}

Note: Expressed in national currencies.

Source: OECD Wealth Distribution Database (oe.cd/wealth). 


\section{Annex B 2.1.2 Some preliminary evidence on housing and wealth inequality over time}

Does the negative association between homeownership and wealth inequality in a crosscountry perspective in the paper persists in a time series-perspective? This question is very tentatively addressed by looking at developments in wealth inequality in the sub-sample of countries for which comparable time-series are available in the OECD Wealth distribution database. Despite attempts to ensure methodological consistency over time, these data should be interpreted with care. In addition, the changes refer to short time spans over recent periods, which is somewhat problematic as long time series are needed to analyse the link between changes in housing conditions and in wealth inequality. Still, the data suggest that wealth inequality at the bottom of the distribution is in the short run most sensitive to changes in homeownership and in house prices (Figure 34):

- The share of net wealth accruing to bottom $40 \%$ households has tended to increase in countries with recent rises in homeownership, like France, Norway and Korea, and to decline in countries having experienced recent reductions in homeownership, like the Slovak Republic and Portugal (Figure 34, Panel A).

- The share of net wealth accruing to bottom $40 \%$ households has tended to decline in countries with recent declines in house prices, especially in highownership countries such as Greece, Spain, Italy, Portugal and the Slovak Republic. By contrast, countries with recent increases in house prices have seen either little change in bottom wealth shares like Canada and the United States (Figure 34, Panel B).

- Changes in top wealth shares are not significantly associated with changes in homeownership and in house prices. The lack of sensitivity to house prices of top compared to bottom wealth households is likely to reflect the fact that households at the bottom of the distribution have either very little assets, when they are renters, or no other assets than their house, when they are owners. Overall, this suggests that in countries where homeownership is widespread, bottom households tend to be particularly sensitive to changes in house prices. 
Figure 34. Developments in homeownership and house prices can affect wealth inequality

Panel A. Changes in homeownership and changes in net wealth inequality, bottom $40 \%$ share

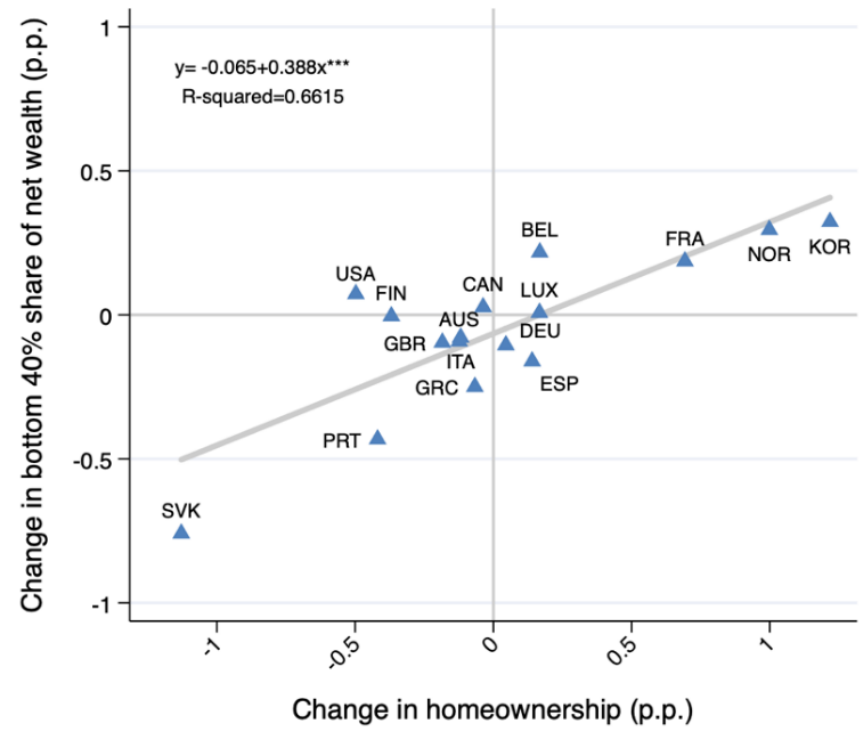

Panel B. Changes in real house prices and changes in net wealth inequality, bottom $40 \%$ share

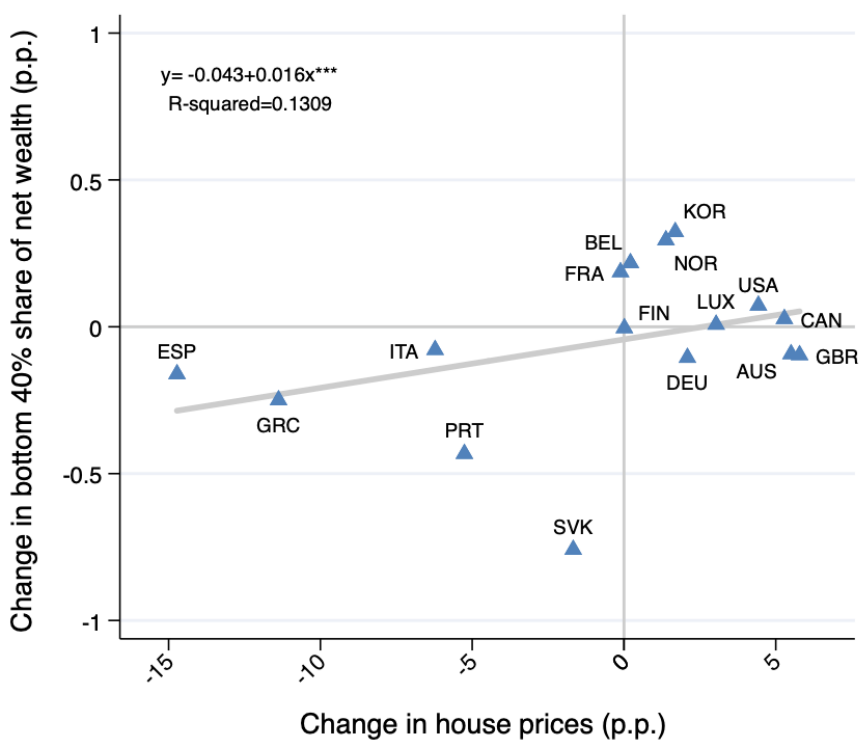

Note: Annual average changes in percentage points (p.p). The figure only shows the OECD countries for which the WDD database provides time-series data that are comparable across waves. The specific period differs across countries: 20122014 (Australia, Norway), 2010-2014 (Belgium, Italy, Norway, the Slovak Republic), 2010-2013 (Portugal), 2009-2014 (Greece, France, Finland), 2009-2012 (Spain), 2011-2014 (Germany, Luxembourg), 2013-2015 (Korea), 2012-2016 (Canada), 2013-2016, (United Kingdom, United States).

Source: OECD Wealth Distribution Database (oe.cd/wealth) and OECD Analytical House Price Database. 


\section{Annex C 2.1.3 Wealth regressions: econometric methodology and results}

To dig into the question of homeownership and wealth accumulation, median country-level and pooled regressions are run to estimate a model of wealth accumulation and derive the effect of housing tenure on household wealth. ${ }^{39}$ The estimated equation features housing tenure status and an extensive array of household-level explanatory variables such as age, household size, education, income, labour market status, as well as inheritance (i.e. whether a member of the household has received any gift or inheritance, whether the household main residence has been inherited).

The parameter of interest is the effect of being homeowner (as opposed to renter) on the level of wealth, in other words the elasticity of wealth with respect to homeownership. This paper relies on the Inverse Hyperbolic sine (IHS) and not the more popular log transformation to estimate the elasticity because wealth can be zero or negative. This approach is based on Pence $\left(2006_{[45]}\right)$ and has become standard in the wealth literature. Deriving the elasticities from IHS wealth regression coefficients is not trivial and some studies have a "naïve" interpretation of their estimates. This paper relies on recent work by Bellemare and Wichman $\left(2018_{[46]}\right)$ who have formally derived the interpretation of estimated coefficients obtained from regressing an IHS-transformed variable on a dummy variable (as housing tenure is a dummy variable). The next paragraphs explain the wealth regression methodology used to estimate wealth tenure gaps and provide detailed regression results.

\section{The Inverse Hyperbolic sine transformation}

The IHS transformation allows for retrieving the properties of the $\log$ transformation in the case of wealth, allowing for negative and zero values. The IHS function $\operatorname{arcsinh}(w)$ approximates $w$ when $w$ is small, and $\log (x)$ when $w$ is large. It is defined as follows:

$$
\operatorname{arcsinh}(w)=\log \left(w+\sqrt{w^{2}+1}\right)
$$

To interpret regression coefficients, start by considering a simple regression model with a single continuous regressor as:

$$
y=\operatorname{arcsinh}(w)=\alpha+\beta x+\mu
$$

In that case, Pence $\left(2006_{[45]}\right)$ shows that $\beta$ can be interpreted as an elasticity when $w$ is large enough for the IHS to approximate a $\log$ :

$$
\beta=\frac{d \operatorname{arcsinh}(w)}{d x}=\frac{1}{\sqrt{w^{2}+1}} \frac{d w}{d x} \approx \frac{1}{w} \frac{d w}{d x}=\frac{d \log w}{d x}
$$

This property results from deriving $\operatorname{arcsinh}(w)$ on $x$ which requires that the regressor be continuous. When it comes to a binary regressor, such as a dummy equal to 1 for homeowners and 0 for renters, this relationship no longer holds. Consider the model below:

$$
y=\operatorname{arcsinh}(w)=\alpha+\beta * \text { owner }+\mu
$$

${ }^{39}$ See e.g. (Arrondel et al., 2014 ${ }_{[19]}$ ) and (Wind and Dewilde, $2017_{[20]}$ ) for wealth accumulation models and for an econometric assessment of the wealth tenure gap. 
The coefficient $\beta$ cannot be cannot interpreted as an elasticity and researchers usually make use of the ratio $\bar{R}$ of the conditional means in order to interpret the regression coefficient associated with a dummy:

$$
\bar{R}=\frac{E(w \mid \text { owner }=1)}{E(w \mid \text { owner }=0)}
$$

In a standard $\log$ regression, the coefficient $\beta$ of a dummy variable is understood as the $\log$ ratio of the average wealth of owners over the average wealth of renters: $\beta=\log \frac{E(w \mid \text { owner })}{E(w \mid \text { renter })}$. The ratio of the conditional means $\bar{R}$ is thus given by $e^{\beta}$. Pence does not provide an explicit interpretation of coefficient of dummy variables in the case of IHS-transformed variables. Bellemare and Wichman $\left(2018_{[46]}\right)$ provide the expression of the proportional effect of a dummy variable on $y$ :

$$
\bar{R}=\frac{E(w \mid \text { owner }=1)}{E(w \mid \text { owner }=0)}=\frac{\sinh (\hat{\alpha}+\hat{\beta}+\hat{\mu})}{\sinh (\hat{\alpha}+\hat{\mu})}
$$

Where sinh is the reverse IHS transformation: $\sinh (y)=w=\frac{e^{y}-e^{-y}}{2}$.

The exact expression of $\bar{R}$ is cumbersome, especially in the case of more than one variable. A simpler approximation is given by:

$$
e^{y}=w+\sqrt{w^{2}+1} \approx 2 w \text { when } w \text { is large enough }
$$

That yields the same result as with the log transformation:

$$
\bar{R}=\frac{E(w \mid \text { owner }=1)}{E(w \mid \text { owner }=0)} \approx e^{\widehat{\beta}}
$$

Citing Kennedy (1981 $\left.{ }_{[47]}\right)$, Bellemare and Wichman recommend using a small-sample bias correction:

$$
\bar{R} \approx e^{\widehat{\beta}-0.5 \operatorname{Var}(\widehat{\beta})} .
$$

In other words, when regressing the model $y=\alpha+\beta *$ owner $+\mu$ where $y$ is the IHStransformed wealth, the ratio of average owner wealth over average renter wealth is given by $\hat{\bar{R}}=e^{\widehat{\beta}-0.5 \operatorname{Var}(\widehat{\beta})}$, and not $\hat{\beta}$.

\section{Estimating the wealth tenure gap}

The paper uses median regressions in order to estimate wealth tenure gaps following standard practice in the wealth literature. Table 7 and Table 8 provide detailed results for the net wealth and financial median regressions. Both regressions are ran on multiply imputed datasets and the resulting standard errors are computed using Rubin's law (Rubin, 1987 ${ }_{[44]}$ ). 
Table 7. Net wealth regression: detailed results

\begin{tabular}{|c|c|c|c|c|c|c|c|c|c|}
\hline & Austria & Belgium & Germany & Estonia & Spain & Finland & France & Greece & Hungary \\
\hline \multirow{2}{*}{$\begin{array}{l}\text { Number of household } \\
\text { members aged } 16+\end{array}$} & $-0.083^{*}$ & 0.008 & 0.108 & $0.133^{*}$ & -0.018 & 0.025 & $0.155^{* \star *}$ & 0.042 & $0.084^{* *}$ \\
\hline & $(0.038)$ & $(0.044)$ & $(0.073)$ & $(0.054)$ & $(0.025)$ & $(0.027)$ & $(0.021)$ & $(0.029)$ & $(0.030)$ \\
\hline \multirow[t]{2}{*}{ Age } & $0.037^{* * *}$ & $0.071^{* * *}$ & -0.007 & -0.002 & $0.076^{* * *}$ & $0.057^{* * *}$ & $0.027^{* * *}$ & 0.027 & $0.045^{* * *}$ \\
\hline & $(0.010)$ & $(0.015)$ & $(0.028)$ & $(0.018)$ & $(0.012)$ & $(0.010)$ & $(0.006)$ & $(0.016)$ & $(0.008)$ \\
\hline \multirow[t]{2}{*}{ Age sq. } & $-0.000 *$ & -0.000 ** & 0.000 & 0.000 & $-0.001^{* * *}$ & -0.000 ** & -0.000 * & 0.000 & $-0.000^{* * *}$ \\
\hline & $(0.000)$ & $(0.000)$ & $(0.000)$ & $(0.000)$ & $(0.000)$ & $(0.000)$ & $(0.000)$ & $(0.000)$ & $(0.000)$ \\
\hline \multirow{2}{*}{$\begin{array}{l}\text { Education : Less than } \\
\text { upper secondary }\end{array}$} & $-0.303^{* * *}$ & $-0.272^{* *}$ & $-1.179 * * *$ & $-0.557^{* * *}$ & $-0.203^{* *}$ & $-0.103^{*}$ & $-0.311^{* * *}$ & $-0.260^{* * *}$ & $-0.554^{* * *}$ \\
\hline & $(0.090)$ & $(0.089)$ & $(0.345)$ & $(0.131)$ & $(0.074)$ & $(0.048)$ & $(0.040)$ & $(0.062)$ & $(0.051)$ \\
\hline \multirow[t]{2}{*}{ Education: Tertiary } & 0.182 ** & 0.077 & $0.462^{* * *}$ & $0.374^{* * *}$ & $0.179^{*}$ & 0.124 ** & $0.406^{* * *}$ & $0.277^{* * *}$ & $0.611^{* * *}$ \\
\hline & $(0.070)$ & $(0.079)$ & $(0.096)$ & $(0.081)$ & $(0.084)$ & $(0.041)$ & $(0.036)$ & $(0.077)$ & $(0.050)$ \\
\hline \multirow{2}{*}{$\begin{array}{l}\text { Labour market status : } \\
\text { Self-employed }\end{array}$} & $0.373^{* *}$ & 0.659 *** & $0.717^{* * *}$ & $1.041^{* * *}$ & $0.808^{* * *}$ & $0.644^{* * *}$ & $0.693^{* * *}$ & $0.704^{* * *}$ & $0.696^{* * *}$ \\
\hline & $(0.121)$ & $(0.189)$ & $(0.200)$ & $(0.234)$ & $(0.095)$ & $(0.051)$ & $(0.065)$ & $(0.087)$ & $(0.080)$ \\
\hline \multirow{2}{*}{$\begin{array}{l}\text { Labour market status: } \\
\text { Unemployed }\end{array}$} & $-2.193^{*}$ & -0.609 * & $-2.044^{* * *}$ & -0.033 & 0.043 & -0.120 & $-0.448 * * *$ & -0.254 & -0.399 * \\
\hline & (0.959) & $(0.244)$ & $(0.358)$ & $(0.212)$ & $(0.079)$ & $(0.113)$ & $(0.091)$ & $(0.173)$ & $(0.176)$ \\
\hline \multirow{2}{*}{$\begin{array}{l}\text { Labour market status: } \\
\text { Retired }\end{array}$} & 0.067 & -0.090 & -0.051 & -0.132 & $0.175^{*}$ & $0.230^{* * *}$ & $0.163^{* * *}$ & 0.025 & 0.007 \\
\hline & $(0.096)$ & $(0.078)$ & $(0.176)$ & $(0.151)$ & $(0.077)$ & $(0.059)$ & $(0.048)$ & $(0.106)$ & $(0.059)$ \\
\hline \multirow{2}{*}{$\begin{array}{l}\text { Gross income (IHS- } \\
\text { transformed) }\end{array}$} & $0.909^{* * *}$ & $0.477^{* * *}$ & $0.517^{* * *}$ & $0.305^{* *}$ & $0.366^{* * *}$ & $0.785^{* * *}$ & $0.206^{* * *}$ & $0.248 * * *$ & $0.389^{* * *}$ \\
\hline & $(0.087)$ & $(0.091)$ & $(0.145)$ & $(0.093)$ & $(0.069)$ & $(0.051)$ & $(0.031)$ & $(0.046)$ & $(0.067)$ \\
\hline \multirow[t]{2}{*}{ Homeowner } & 2.528 *** & $2.757^{* * *}$ & $2.328^{* * *}$ & 3.072 *** & $2.718^{* * *}$ & $3.384^{* * *}$ & $2.293^{* * *}$ & 3.056 *** & $2.676^{* * *}$ \\
\hline & $(0.065)$ & $(0.165)$ & $(0.112)$ & $(0.225)$ & $(0.117)$ & $(0.103)$ & $(0.049)$ & $(0.108)$ & $(0.126)$ \\
\hline \multirow{2}{*}{$\begin{array}{l}\text { Has inherited main } \\
\text { residence }\end{array}$} & $0.279^{* * *}$ & 0.055 & 0.212 & $0.271^{*}$ & 0.019 & $0.442^{* * *}$ & 0.058 & -0.051 & -0.044 \\
\hline & $(0.068)$ & $(0.260)$ & $(0.126)$ & $(0.109)$ & $(0.099)$ & $(0.092)$ & $(0.058)$ & $(0.054)$ & $(0.057)$ \\
\hline \multirow{2}{*}{$\begin{array}{l}\text { Has received any } \\
\text { substantial gift or } \\
\text { inheritance }\end{array}$} & $0.404^{* * *}$ & $0.421^{* * *}$ & $0.519^{* * *}$ & $0.343^{* * *}$ & $0.418^{* * *}$ & $0.222^{* * *}$ & $0.435^{* * *}$ & $0.376^{* *}$ & $0.226^{* * *}$ \\
\hline & $(0.061)$ & $(0.064)$ & $(0.097)$ & $(0.092)$ & $(0.059)$ & $(0.031)$ & $(0.030)$ & $(0.122)$ & $(0.044)$ \\
\hline \multirow[t]{2}{*}{ Male } & 0.003 & -0.017 & -0.057 & 0.088 & 0.012 & 0.005 & $0.101^{* *}$ & $0.153^{*}$ & 0.028 \\
\hline & $(0.065)$ & $(0.083)$ & $(0.114)$ & $(0.099)$ & $(0.060)$ & $(0.037)$ & $(0.033)$ & $(0.060)$ & $(0.037)$ \\
\hline
\end{tabular}


Table 7 Net wealth regression: detailed results (continued)

\begin{tabular}{|c|c|c|c|c|c|c|c|c|}
\hline & Italy & Luxembourg & Latvia & Netherlands & Portugal & Slovenia & $\begin{array}{l}\text { Slovak } \\
\text { Republic }\end{array}$ & $\begin{array}{l}\text { Pooled } \\
\text { EU } \\
\text { OECD }\end{array}$ \\
\hline \multirow{2}{*}{$\begin{array}{l}\text { Number of household members } \\
\text { aged } 16+\end{array}$} & 0.002 & 0.028 & 0.067 & 0.017 & 0.006 & $0.154^{* * *}$ & $0.054^{*}$ & -0.014 \\
\hline & $(0.019)$ & $(0.045)$ & $(0.060)$ & $(0.085)$ & $(0.029)$ & $(0.025)$ & $(0.027)$ & $(0.011)$ \\
\hline \multirow[t]{2}{*}{ Age } & $0.040 * * *$ & 0.050 * & -0.054 & 0.068 & $0.055^{* *}$ & 0.024 & 0.039 ** & $0.030^{* * *}$ \\
\hline & $(0.010)$ & $(0.020)$ & $(0.029)$ & $(0.040)$ & $(0.020)$ & $(0.016)$ & $(0.013)$ & $(0.006)$ \\
\hline \multirow[t]{2}{*}{ Age sq. } & $-0.000^{* * *}$ & 0.000 & 0.001 * & 0.000 & 0.000 & 0.000 & -0.000 ** & $-0.000^{* *}$ \\
\hline & $(0.000)$ & $(0.000)$ & $(0.000)$ & $(0.000)$ & $(0.000)$ & $(0.000)$ & $(0.000)$ & $(0.000)$ \\
\hline \multirow{2}{*}{$\begin{array}{l}\text { Education : Less than upper } \\
\text { secondary }\end{array}$} & $-0.299 * * *$ & $-0.221^{*}$ & $-0.401^{*}$ & -0.164 & -0.230 * & $-0.384^{* * *}$ & $-0.584^{* * *}$ & -0.043 \\
\hline & $(0.038)$ & $(0.092)$ & $(0.204)$ & $(0.174)$ & $(0.102)$ & $(0.076)$ & $(0.090)$ & $(0.026)$ \\
\hline \multirow[t]{2}{*}{ Education: Tertiary } & $0.294^{* \star *}$ & 0.240 * & $0.498^{* * *}$ & -0.077 & $0.297^{* *}$ & $0.463^{* * *}$ & $0.350^{* * *}$ & $0.309^{* * *}$ \\
\hline & $(0.049)$ & $(0.106)$ & $(0.139)$ & $(0.148)$ & $(0.099)$ & $(0.068)$ & $(0.090)$ & $(0.029)$ \\
\hline \multirow{2}{*}{$\begin{array}{l}\text { Labour market status : Self- } \\
\text { employed }\end{array}$} & $0.730 * * *$ & 0.550 ** & $0.723^{* *}$ & 0.382 & $0.978^{* * *}$ & $0.935^{* * *}$ & 0.205 & $0.748^{* * *}$ \\
\hline & $(0.077)$ & (0.193) & $(0.254)$ & (0.299) & $(0.129)$ & $(0.151)$ & $(0.111)$ & $(0.037)$ \\
\hline \multirow[t]{2}{*}{ Labour market status: Unemployed } & 0.390 & -0.642 & -0.144 & -0.105 & -0.051 & $-0.416^{*}$ & $-0.781^{* * *}$ & -0.121 \\
\hline & $(0.205)$ & $(0.515)$ & $(0.376)$ & $(0.468)$ & $(0.150)$ & $(0.212)$ & $(0.216)$ & $(0.065)$ \\
\hline \multirow[t]{2}{*}{ Labour market status: Retired } & $0.157^{* \star *}$ & -0.042 & -0.046 & -0.084 & 0.125 & 0.005 & 0.036 & 0.079 * \\
\hline & $(0.045)$ & $(0.139)$ & $(0.231)$ & $(0.248)$ & $(0.110)$ & $(0.103)$ & $(0.093)$ & $(0.038)$ \\
\hline \multirow[t]{2}{*}{ Gross income (IHS-transformed) } & $0.284^{* * *}$ & $0.461^{* * *}$ & $0.668^{* * *}$ & 0.097 & $0.494^{* * *}$ & 0.066 & $0.114^{* *}$ & $0.584^{* * *}$ \\
\hline & $(0.045)$ & $(0.118)$ & $(0.151)$ & $(0.098)$ & $(0.081)$ & $(0.040)$ & $(0.043)$ & $(0.029)$ \\
\hline \multirow[t]{2}{*}{ Homeowner } & $3.026 * * *$ & $2.769 * * *$ & $4.164^{* * *}$ & $2.488 * * *$ & $3.051^{* * *}$ & $3.425^{* * *}$ & $3.131^{* * *}$ & $2.556 * * *$ \\
\hline & $(0.050)$ & $(0.177)$ & $(0.349)$ & $(0.195)$ & (0.198) & $(0.245)$ & $(0.223)$ & $(0.034)$ \\
\hline \multirow[t]{2}{*}{ Has inherited main residence } & -0.036 & $0.414^{* *}$ & 0.234 & 0.415 & 0.102 & -0.036 & -0.045 & 0.045 \\
\hline & $(0.033)$ & $(0.141)$ & $(0.157)$ & (1.097) & $(0.113)$ & $(0.063)$ & $(0.070)$ & $(0.027)$ \\
\hline \multirow{2}{*}{$\begin{array}{l}\text { Has received any substantial gift or } \\
\text { inheritance }\end{array}$} & $0.257^{* * *}$ & 0.222 ** & 0.418 * & 0.423 * & $0.421^{* * *}$ & $0.297^{* * *}$ & $0.204^{* *}$ & $0.436^{* * *}$ \\
\hline & $(0.034)$ & $(0.077)$ & $(0.173)$ & (0.191) & $(0.062)$ & $(0.066)$ & $(0.064)$ & $(0.022)$ \\
\hline \multirow[t]{2}{*}{ Male } & 0.036 & 0.072 & 0.114 & 0.232 & 0.063 & 0.061 & 0.009 & 0.060 ** \\
\hline & $(0.037)$ & $(0.082)$ & $(0.135)$ & $(0.158)$ & $(0.069)$ & $(0.058)$ & $(0.062)$ & $(0.022)$ \\
\hline
\end{tabular}

Note: $* * * \mathrm{p}<0.001 ; * * \mathrm{p}<0.01 ; * \mathrm{p}<0.05$. Reference category for education is upper- and post-secondary, for labour market status employee and for gender female. Intercept not shown. "Pooled EU OECD" refers to crosscountry fixed effects regressions. Regressions ran on multiply imputed datasets and the resulting standard errors are computed using Rubin's law

Source: HFCS and authors' calculations 
Table 8. Financial wealth regression: detailed results

\begin{tabular}{|c|c|c|c|c|c|c|c|c|c|}
\hline & Austria & Belgium & Germany & Estonia & Spain & Finland & France & Greece & Hungary \\
\hline \multirow{2}{*}{$\begin{array}{l}\text { Number of household } \\
\text { members aged } 16+\end{array}$} & -0.140 & -0.076 & 0.067 & 0.254 * & -0.082 & -0.066 & 0.059 & -0.260 & $0.193^{* *}$ \\
\hline & $(0.077)$ & $(0.131)$ & $(0.091)$ & $(0.102)$ & $(0.105)$ & $(0.055)$ & $(0.054)$ & $(0.162)$ & $(0.064)$ \\
\hline \multirow[t]{2}{*}{ Age } & 0.046 * & 0.069 & -0.022 & -0.070 & 0.087 & -0.024 & $-0.042^{* *}$ & 0.028 & $0.166^{* * *}$ \\
\hline & $(0.019)$ & $(0.041)$ & $(0.038)$ & $(0.037)$ & $(0.048)$ & $(0.014)$ & $(0.014)$ & $(0.051)$ & $(0.037)$ \\
\hline \multirow[t]{2}{*}{ Age sq. } & 0.000 & 0.000 & 0.000 & $0.001^{* *}$ & -0.001 & 0.000 ** & $0.001^{* * *}$ & 0.000 & $-0.002^{* * *}$ \\
\hline & $(0.000)$ & $(0.000)$ & $(0.000)$ & $(0.000)$ & $(0.000)$ & $(0.000)$ & $(0.000)$ & $(0.000)$ & $(0.000)$ \\
\hline \multirow{2}{*}{$\begin{array}{l}\text { Education : Less than } \\
\text { upper secondary }\end{array}$} & -0.490 ** & -0.411 & $-1.723^{* * *}$ & $-0.946^{*}$ & $-0.603^{* *}$ & $-0.351^{* * *}$ & $-0.667^{* * *}$ & $-0.843^{* *}$ & $-1.995^{* * *}$ \\
\hline & $(0.167)$ & $(0.311)$ & $(0.438)$ & $(0.373)$ & $(0.216)$ & $(0.099)$ & $(0.135)$ & $(0.276)$ & $(0.326)$ \\
\hline \multirow[t]{2}{*}{ Education: Tertiary } & 0.239 & 0.305 & $0.623^{* * *}$ & $1.202^{* * *}$ & 0.425 & $0.404^{* * *}$ & $0.758^{* * *}$ & 0.760 * & $1.001^{* * *}$ \\
\hline & (0.153) & $(0.244)$ & $(0.146)$ & $(0.208)$ & $(0.224)$ & $(0.100)$ & $(0.083)$ & $(0.300)$ & $(0.152)$ \\
\hline \multirow{2}{*}{$\begin{array}{l}\text { Labour market status : } \\
\text { Self-employed }\end{array}$} & 0.140 & 0.186 & 0.212 & 0.611 & $0.845^{* *}$ & $0.732 * * *$ & $0.542^{* * *}$ & $0.953 * *$ & 0.445 \\
\hline & $(0.222)$ & $(0.432)$ & $(0.302)$ & $(0.322)$ & $(0.279)$ & (0.121) & (0.133) & $(0.339)$ & $(0.231)$ \\
\hline \multirow{2}{*}{$\begin{array}{l}\text { Labour market status: } \\
\text { Unemployed }\end{array}$} & $-1.836^{* * *}$ & $-1.392 *$ & -1.394 * & -0.612 & -0.261 & $-0.475^{* *}$ & $-0.838^{* * *}$ & -1.299 & -0.473 \\
\hline & $(0.557)$ & $(0.586)$ & $(0.642)$ & $(0.585)$ & $(0.322)$ & $(0.183)$ & $(0.164)$ & $(0.725)$ & $(0.530)$ \\
\hline \multirow{2}{*}{$\begin{array}{l}\text { Labour market status: } \\
\text { Retired }\end{array}$} & -0.061 & -0.289 & -0.192 & -0.198 & 0.007 & $0.431^{* *}$ & 0.148 & 0.219 & -0.340 \\
\hline & $(0.211)$ & $(0.392)$ & $(0.428)$ & $(0.421)$ & $(0.301)$ & $(0.146)$ & $(0.126)$ & $(0.388)$ & $(0.248)$ \\
\hline \multirow{2}{*}{$\begin{array}{l}\text { Gross income (IHS- } \\
\text { transformed) }\end{array}$} & 1.264 *** & $0.905^{* * *}$ & $0.701^{* * *}$ & 0.396 *** & $0.672^{* * *}$ & $1.048^{* \star *}$ & $0.348^{* * *}$ & 0.496 *** & $0.745^{* * *}$ \\
\hline & $(0.151)$ & $(0.173)$ & $(0.116)$ & $(0.074)$ & $(0.149)$ & $(0.097)$ & $(0.058)$ & $(0.070)$ & $(0.096)$ \\
\hline \multirow[t]{2}{*}{ Homeowner } & $0.659^{* * *}$ & 0.952 ** & $0.819 * * *$ & $0.966^{* *}$ & 0.646 * & $0.863^{* * *}$ & $0.878^{* * *}$ & 0.884 * & 0.164 \\
\hline & $(0.145)$ & $(0.300)$ & $(0.211)$ & $(0.313)$ & $(0.259)$ & $(0.129)$ & $(0.108)$ & $(0.349)$ & $(0.284)$ \\
\hline \multirow{2}{*}{$\begin{array}{l}\text { Has inherited main } \\
\text { residence }\end{array}$} & 0.031 & -0.585 & 0.010 & -0.086 & -0.021 & 0.269 & -0.221 & -0.359 & -0.326 \\
\hline & $(0.156)$ & $(0.619)$ & $(0.254)$ & $(0.274)$ & $(0.249)$ & $(0.247)$ & $(0.191)$ & $(0.243)$ & $(0.190)$ \\
\hline \multirow{2}{*}{$\begin{array}{l}\text { Has received any } \\
\text { substantial gift or } \\
\text { inheritance }\end{array}$} & 0.362 ** & $1.152^{* * *}$ & 0.482 ** & 0.333 & $0.726 * * *$ & $0.362^{* * *}$ & $0.818^{* * *}$ & $1.702^{* * *}$ & 0.528 *** \\
\hline & $(0.123)$ & $(0.182)$ & $(0.179)$ & $(0.222)$ & $(0.200)$ & $(0.085)$ & $(0.072)$ & $(0.336)$ & $(0.146)$ \\
\hline \multirow[t]{2}{*}{ Male } & -0.037 & 0.175 & -0.126 & 0.454 * & 0.138 & 0.085 & 0.121 & 0.409 & $0.416^{* * *}$ \\
\hline & (0.121) & $(0.220)$ & $(0.207)$ & $(0.219)$ & $(0.234)$ & $(0.075)$ & $(0.078)$ & $(0.261)$ & $(0.120)$ \\
\hline
\end{tabular}

Note: $* * * \mathrm{p}<0.001 ; * * \mathrm{p}<0.01 ; * \mathrm{p}<0.05$. Reference category for education is upper- and post-secondary, for labour market status employee and for gender female. Intercept not shown. "Pooled EU OECD" refers to crosscountry fixed effects regressions. Regressions ran on multiply imputed datasets and the resulting standard errors are computed using Rubin's law

Source: HFCS and authors' calculations 
Table 8 Financial wealth regression: detailed results (continued)

\begin{tabular}{|c|c|c|c|c|c|c|c|c|}
\hline & Italy & Luxembourg & Latvia & Netherlands & Portugal & Slovenia & $\begin{array}{c}\text { Slovak } \\
\text { Republic }\end{array}$ & $\begin{array}{l}\text { Pooled EU } \\
\text { OECD }\end{array}$ \\
\hline \multirow[t]{2}{*}{$\begin{array}{l}\text { Number of household members } \\
\text { aged } 16+\end{array}$} & -0.237 & -0.197 & -0.458 & 0.006 & -0.095 & 0.089 & 0.116 & $-0.210^{* * *}$ \\
\hline & $(0.049)$ & $(0.134)$ & (0.308) & (0.195) & $(0.087)$ & $(0.138)$ & $(0.102)$ & (0.031) \\
\hline \multirow[t]{2}{*}{ Age } & $0.071^{*}$ & 0.055 & 0.017 & 0.034 & 0.014 & -0.012 & 0.049 & 0.002 \\
\hline & $(0.033)$ & $(0.045)$ & $(0.083)$ & $(0.058)$ & $(0.037)$ & $(0.060)$ & $(0.060)$ & $(0.013)$ \\
\hline \multirow[t]{2}{*}{ Age sq. } & 0.000 & 0.000 & 0.000 & 0.000 & 0.000 & 0.000 & -0.001 & 0.000 \\
\hline & $(0.000)$ & $(0.000)$ & (0.001) & $(0.001)$ & $(0.000)$ & $(0.001)$ & (0.001) & $(0.000)$ \\
\hline \multirow[t]{2}{*}{$\begin{array}{l}\text { Education : Less than upper } \\
\text { secondary }\end{array}$} & -0.610 & $-0.654^{* *}$ & -1.869 & -0.550 & -0.754 & -1.159 ** & $-3.162^{* * *}$ & $-0.582^{* * *}$ \\
\hline & $(0.104)$ & $(0.236)$ & (0.633) & $(0.348)$ & $(0.244)$ & $(0.389)$ & (0.731) & $(0.058)$ \\
\hline \multirow[t]{2}{*}{ Education: Tertiary } & 0.426 ** & 0.578 * & $1.244^{* *}$ & 0.338 & 0.478 * & $\begin{array}{r}1.508 \\
* * *\end{array}$ & $0.982^{* * *}$ & $0.587^{* \star *}$ \\
\hline & $(0.150)$ & $(0.269)$ & $(0.418)$ & $(0.257)$ & $(0.233)$ & $(0.247)$ & $(0.247)$ & (0.061) \\
\hline \multirow{2}{*}{$\begin{array}{l}\text { Labour market status : Self- } \\
\text { employed }\end{array}$} & 0.204 & 0.304 & 1.224 & 0.218 & $0.632^{* *}$ & 0.158 & 0.485 & $0.343^{* *}$ \\
\hline & (0.198) & $(0.433)$ & (0.688) & $(0.545)$ & $(0.239)$ & $(0.542)$ & (0.354) & $(0.116)$ \\
\hline \multirow{2}{*}{$\begin{array}{l}\text { Labour market status: } \\
\text { Unemployed }\end{array}$} & -0.308 & -0.639 & -0.461 & 0.291 & -0.170 & -1.290 & $-3.419^{* * *}$ & -0.538 *** \\
\hline & $(0.563)$ & $(0.767)$ & $(0.852)$ & $(0.564)$ & $(0.333)$ & $(1.015)$ & $(0.892)$ & $(0.107)$ \\
\hline \multirow[t]{2}{*}{ Labour market status: Retired } & $0.471^{* *}$ & -0.131 & -0.762 & -0.055 & 0.144 & 0.385 & 0.435 & -0.033 \\
\hline & $(0.153)$ & $(0.373)$ & $(0.802)$ & $(0.413)$ & $(0.256)$ & $(0.494)$ & $(0.476)$ & $(0.088)$ \\
\hline \multirow[t]{2}{*}{ Gross income (IHS-transformed) } & $\begin{array}{r}0.806 \\
* * *\end{array}$ & $0.899^{* * *}$ & 1.306 & 0.140 & $\begin{array}{r}0.870 \\
* \star *\end{array}$ & 0.246 & $0.415^{* *}$ & $0.967^{* * *}$ \\
\hline & $(0.053)$ & $(0.224)$ & $(0.392)$ & $(0.196)$ & $(0.133)$ & $(0.126)$ & $(0.149)$ & $(0.049)$ \\
\hline \multirow[t]{2}{*}{ Homeowner } & $\underset{* * *}{0.862}$ & 0.787 * & 0.658 & $0.953^{* * *}$ & $\begin{array}{r}1.063 \\
* * *\end{array}$ & $0.694^{*}$ & 0.583 & $0.632^{* * *}$ \\
\hline & $(0.125)$ & $(0.334)$ & $(0.476)$ & $(0.248)$ & $(0.219)$ & $(0.344)$ & $(0.377)$ & $(0.056)$ \\
\hline \multirow[t]{2}{*}{ Has inherited main residence } & 0.012 & 0.632 & -0.223 & 0.802 & -0.090 & -0.368 & -0.261 & -0.200 * \\
\hline & $(0.116)$ & $(0.421)$ & $(0.454)$ & $(1.501)$ & $(0.371)$ & $(0.373)$ & $(0.329)$ & $(0.082)$ \\
\hline \multirow[t]{2}{*}{$\begin{array}{l}\text { Has received any substantial gift } \\
\text { or inheritance }\end{array}$} & $\begin{array}{r}0.485 \\
* * *\end{array}$ & 0.474 * & 0.531 & $0.853^{* *}$ & 0.764 & 0.479 & 0.494 * & $0.633^{* * *}$ \\
\hline & $(0.100)$ & $(0.230)$ & (0.594) & $(0.299)$ & $(0.161)$ & $(0.277)$ & $(0.243)$ & $(0.054)$ \\
\hline \multirow[t]{2}{*}{ Male } & 0.161 & 0.273 & 0.566 & 0.545 & $0.357^{* *}$ & -0.019 & 0.025 & 0.194 ** \\
\hline & $(0.135)$ & $(0.208)$ & $(0.354)$ & $(0.344)$ & $(0.138)$ & $(0.217)$ & $(0.221)$ & $(0.060)$ \\
\hline
\end{tabular}

Note: $* * * \mathrm{p}<0.001 ; * * \mathrm{p}<0.01 ; * \mathrm{p}<0.05$. Reference category for education is upper- and post-secondary, for labour market status employee and for gender female. Intercept not shown. "Pooled EU OECD" refers to crosscountry fixed effects regressions. Regressions ran on multiply imputed datasets and the resulting standard errors are computed using Rubin's law.

Source: HFCS and authors' calculations

The interpretation of the estimated homeownership coefficient is as follows. For Italy, this coefficient is equal to 3.026 in the case of net wealth (Table 4). A naïve quantification would be that the median owner is three times wealthier than the median renter, all else equal. The correct quantification of the tenure gap is approximated by $\hat{\bar{R}}=e^{\widehat{\beta}-0.5 \operatorname{Var}(\widehat{\beta})}=20.6$. In Italy, the median homeowner is 20.6 times wealthier than the median renter. This figure is closer to the uncontrolled ratio of median owner wealth over median renter wealth, which in Italy is equal to 30.5 . This implies that the control variables explain around two thirds of the net wealth tenure gap in the case of Italy.

The wealth tenure gap estimates may seem surprisingly high. One reason for this is that the median wealth of renters is often very low, especially compared with the mean wealth of 
renters resulting in a highly skewed distribution. Many renters have no wealth, and the median is particularly sensitive to this critical mass around zero in the distribution. In Italy, the mean net wealth of renters is equal to $29969 €$, whereas the mean net wealth of homeowners is equal to $317777 €$, thus yielding a mean net wealth ratio of owners over renters of 10.6 (see Table 9).

Table 9. Wealth of renters and owners: mean versus median

\begin{tabular}{rrrrr}
\hline Country & $\begin{array}{c}\text { Renters: median net } \\
\text { wealth }\end{array}$ & $\begin{array}{c}\text { Owners: median net } \\
\text { wealth }\end{array}$ & $\begin{array}{c}\text { Renters: mean net } \\
\text { wealth }\end{array}$ & $\begin{array}{c}\text { Owners: mean net } \\
\text { wealth }\end{array}$ \\
\hline Austria & 11,994 & 300,373 & 53,611 & 483,323 \\
Belgium & 9,391 & 297,476 & 109,354 & 423,518 \\
Estonia & 1,512 & 59,338 & 32,510 & 116,835 \\
Finland & 2,100 & 188,200 & 20,814 & 278,653 \\
France & 11,789 & 228,384 & 49,996 & 379,263 \\
Germany & 10,000 & 220,740 & 51,835 & 418,123 \\
Greece & 3,020 & 88,082 & 27,274 & 134,010 \\
Hungary & 1,470 & 31,840 & 10,466 & 58,387 \\
Ireland & 3,500 & 170,500 & 31,297 & 293,812 \\
Italy & 7,000 & 213,800 & 29,969 & 317,777 \\
Latvia & 150 & 19,884 & 18,936 & 46,698 \\
Luxembourg & 18,030 & 655,049 & 161,619 & $1,059,120$ \\
Netherlands & 10,917 & 192,770 & 32,481 & 238,786 \\
Poland & 939 & 76,901 & 11,676 & 121,136 \\
Portugal & 2,850 & 101,039 & 43,807 & 193,929 \\
Slovak & 2,747 & 57,675 & 8,765 & 75,859 \\
Republic & & & & 168,037 \\
Slovenia & 2,608 & 104,890 & 52,646 & 315,364 \\
Spain & 7,597 & 190,000 & 67,862 & \\
\hline
\end{tabular}

Note: Unit is the country currency.

Source: HFCS and author's calculations. 


\section{References}

Akgun, O., B. Cournède and J. Fournier (2017), "Effects of the Tax Mix on Inequality and Growth", OECD Economics Department Working Papers, OECD Publishing.

Alam, Z. et al. (2019), Digging Deeper-Evidence on the Effects of Macroprudential Policies from a New Database IMF Working Paper Monetary and Capital Markets Department Digging Deeper-Evidence on the Effects of Macroprudential Policies from a New Database.

Albuquerque, B., U. Baumann and G. Krustev (2014), "Has US Household Deleveraging Ended? A Model-Based Estimate of Equilibrium Debt", ECB Working Paper 1643.

André, C. and T. Chalaux (2018), "Building a typology of housing systems to inform policies in OECD and EU member States", Economie et Statistique / Economics and Statistics, http://dx.doi.org/10.24187/ecostat.2018.500t.1943.

Andrews, D. and A. Caldera Sánchez (2011), "The Evolution of Homeownership Rates in Selected OECD Countries: Demographic and Public Policy Influences", OECD Journal: Economic Studies, Vol. 2011/1, http://dx.doi.org/10.1787/eco studies-2011-5kg0vswapmg2.

Andrews, D., A. Caldera Sánchez and Å. Johansson (2011), "Housing Markets and Structural Policies in OECD Countries", OECD Economics Department Working Papers, No. 836, OECD Publishing, Paris, https://dx.doi.org/10.1787/5kgk8t2k9vf3-en.

Arrondel, L. et al. (2014), "How do households allocate their assets? Stylised facts from the Eurosystem Household Finance and Consumption Survey", Document de travail 504, Banque de France, http://www.banque-france.fr.

Atkinson, A. and A. Brandolini (2011), "On the identification of the new middle class", ECINEQ working paper, http://dx.doi.org/10.1080/03085147500000001.

Azpitarte, F. (2010), "The household wealth distribution in Spain: The role of housing and financial wealth", Hacienda Publica Espanola.

Balestra, C. and R. Tonkin (2018), "Inequalities in household wealth across OECD countries: Evidence from the OECD Wealth Distribution Database", OECD Statistics Working Papers, No. 2018/01, OECD Publishing, Paris, https://dx.doi.org/10.1787/7elbf673-en.

Baptista, R. et al. (2016), "Macroprudential policy in an agent-based model of the UK housing market", Bank of England Working paper No. 169.

Bellemare, M. and C. Wichman (2018), "Elasticities and the Inverse Hyperbolic Sine Transformation", http://caseyjwichman.com/wpcontent/uploads/2018/10/BellemareWichmanIHSSeptember2018.pdf (accessed on 18 December 2018).

Bezrukovs, D. (2013), "The role of housing in wealth inequality in Eurozone countries", mimeo.

Bischoff, K. and S. Reardon (2013), Residential Segregation by Income, 1970-2009, US2010.

Bonnet, C., B. Garbinti and S. Grobon (2018), "Rising inequalities in access to home ownership among young households in France, 1973-2013", Economie et Statistique / Economics and Statistics, http://dx.doi.org/10.24187/ecostat.2018.500t.1948.

Brys, B. et al. (2016), "Tax Design for Inclusive Economic Growth", OECD Taxation Working Papers, No. 26, OECD Publishing, Paris, http://dx.doi.org/10.1787/5jlv74ggk0g7-en. 
C(2018)148/REV1 (2018), SUMMARY OF INFORMATION ON PROPOSED HORIZONTAL PROJECTS FOR THE PWB 2019-20.

Caldera Sánchez, A. and D. Andrews (2011), "Residential Mobility and Public Policy in OECD Countries", OECD Journal: Economic Studies, Vol. 2011, http://dx.doi.org/10.1787/19952856.

Carpantier, J., J. Olivera and P. Van Kerm (2018), "Macroprudential policy and household wealth inequality", Journal of International Money and Finance, Vol. 85, pp. 262-277, http://dx.doi.org/10.1016/J.JIMONFIN.2017.11.009.

Catte, P. et al. (2005), "The Contribution of Housing Markets to Cyclical Resilience", OECD Economic Studies, Vol. 2004/1, https://dx.doi.org/10.1787/eco studies-v2004-art6-en.

Causa, O. et al. (2014), "Economic Growth from the Household Perspective: GDP and Income Distribution Developments Across OECD Countries", OECD Economics Department Working Papers, No. 1111, OECD Publishing, Paris, http://dx.doi.org/10.1787/5jz5m89dh0nt-en.

Causa, O. and M. Hermansen (2017), "Income redistribution through taxes and transfers across OECD countries", OECD Economics Department Working Papers, No. 1453, OECD Publishing, Paris, https://dx.doi.org/10.1787/bc7569c6-en.

Causa, O., M. Hermansen and N. Ruiz (2016), "The Distributional Impact of Structural Reforms", OECD Economics Department Working Papers, No. 1342, OECD Publishing, Paris, http://dx.doi.org/10.1787/5jln041nkpwc-en.

Cerutti, E., S. Claessens and L. Laeven (2017), "The use and effectiveness of macroprudential policies: New evidence", Journal of Financial Stability, Vol. 28, pp. 203-224, http://dx.doi.org/10.1016/j.jfs.2015.10.004.

Chetty, R., N. Hendren and L. Katz (2016), The effects of exposure to better neighborhoods on children: New evidence from the moving to opportunity experiment, http://dx.doi.org/10.1257/aer.20150572.

Chiuri, M. and T. Jappelli (2003), "Financial market imperfections and home ownership: A comparative study", European Economic Review, http://dx.doi.org/10.1016/S00142921(02)00273-8.

Cowell, F. et al. (2017), "Wealth, Top Incomes and Inequality", LWS Working Paper Series Luxembourg Income Study (LIS), No. 24.

CTPA/CFA/WP2/A(2018)2 (2018), Working Party No. 2 on Tax Policy Analysis and Tax Statistics: DRAFT AGENDA OF WORKING PARTY NO.2.

Daley, J., B. Coates and T. Wiltshire (2018), Housing affordability: re-imagining the Australian dream Grattan Institute Support Founding members Endowment Supporters, the grattan institute, http://www.grattan.edu.au/.

Davies, J. (2012), "Wealth and Economic Inequality", in The Oxford Handbook of Economic Inequality, http://dx.doi.org/10.1093/oxfordhb/9780199606061.013.0006.

DELSA/ELSA/WP1(2018)6 (2018), Working Party on Social Policy: work on Housing.

ECB (2009), Housing Finance in the euro area, European Central bank, http://www.ecb.europa.eu.

ECO/CPE/WP1(2018)19 (2018), Preliminary results for the 2018 PMR Indicators.

European Commission (2012), European economy: Possible reforms of real estate taxation: Criteria for successful policies, European Commission, http://dx.doi.org/10.2765/24556. 
Fatica, S. and D. Prammer (2017), "Housing and the tax system: how large are the distortions in the euro area?", Fiscal Studies, http://dx.doi.org/10.1111/1475-5890.12159.

FCAC (2017), Home Equity Lines of Credit: Market Trends and Consumer Issues: Public Research Report, Financial Consumer Agency of Canada (FCAC).

Fessler, P., P. Lindner and E. Segalla (2014), "Net wealth across the euro area: why household structure matters and how to control for it", European Central Bank working paper serie No 1663/April 2014, http://www.ecb.europa.eu/pub/pdf/scpwps/ecbwp1663-annexes.zip.

Fischer, S. (2014), "Macroprudential policy in action: Israel", in What have we learned, https://books.google.com/books?hl=en\&lr=\&id=IOCOAwAAQBAJ\&oi=fnd\&pg=PA87\&dq= macroprudential+distributional\&ots=BpXM1NjyeF\&sig=Ah4FjvVVMF1_Mp6mPf0_2MUO7 B4 (accessed on 7 December 2018).

Gambacorta, L. and A. Pabón (2017), "The impact of macroprudential policies and their interaction with monetary policy: an empirical analysis using credit registry data", BIS Working Papers, https://ideas.repec.org/p/bis/biswps/636.html (accessed on 11 December 2018).

Glick, R. and K. Lansing (2010), "Global household leverage, house prices, and consumption", FRBSF Economic Letter, http://homepage.ntu.edu.tw/ nankuang/Global\%20Household\%20Leverage, $\% 20$ House $\% 20$ Pric es, \%20and\%20Consumption-1.pdf (accessed on 4 December 2018).

HFCS (2016), The Household Finance and Consumption Survey Wave 2, European Central Bank Eurosystem.

Huber, S. and T. Schmidt (2016), "Cross-Country Differences in Homeownership: A Cultural Phenomenon", https://sites.google.com/site/stefaniehuber.

HYPOSTAT (2018), A REVIEW OF EUROPE'S MORTGAGE AND HOUSING MARKETS, European Mortgage Federation.

IFS (2018), The IFS Green Budget: October 2018 The Institute for Fiscal Studies.

IMF (2018), Global Financial Stability Report April 2018: A Bumpy Road Ahead.

Kaas, L., G. Kocharkov and E. Preugschat (2015), "Wealth Inequality and Homeownership in Europe Wealth Inequality and Homeownership in Europe *".

Kelly, J., J. Le Blanc and R. Lydon (2018), "Pockets of risk in European Housing Markets: then and now", Research Technical Papers, https://ideas.repec.org/p/cbi/wpaper/12-rt-18.html (accessed on 28 November 2018).

Kennedy, P. (1981), "Estimation with Correctly Interpreted Dummy Variables in Semilogarithmic Equations [The Interpretation of Dummy Variables in Semilogarithmic Equations]", American Economic Review, Vol. 71/4, https://econpapers.repec.org/article/aeaaecrev/v 3a71_3ay 3a1981_3ai_3a4 3ap 3a801.htm (accessed on 24 January 2019).

Kholodilin, K. (2018), "Measuring Stick-Style Housing Policies: A Multi-Country Longitudinal Database of Governmental Regulations", DIW Berlin Discussion Paper, No. 1727, http://dx.doi.org/10.2139/ssrn.3146755.

Kohl, S. (2018), "More Mortgages, More Homes? The Effect of Housing Financialization on Homeownership in Historical Perspective", Politics \& Society, Vol. 46/2, pp. 177-203, http://dx.doi.org/10.1177/0032329218755750. 
Liu, L. (2018), "Regional Labor Mobility in Spain”, IMF WP/18/282, December 2018, IMF.

Lyons, R. (2018), “Credit conditions and the housing price ratio: Evidence from Ireland's boom and bust", Journal of Housing Economics, Vol. 42, pp. 84-96, http://dx.doi.org/10.1016/J.JHE.2018.05.002.

Makoto, N. (2012), Everything You Always Wanted to Know About Reverse Mortgages but Were Afraid to Ask, Federal Reserve of Philadelphia Business Review, http://www.philadelphiafed.org.

Metcalf, G. (2018), "Sand Castles Before the Tide? Affordable Housing in Expensive Cities", Journal of Economic Perspectives, http://dx.doi.org/10.1257/jep.32.1.59.

Mian, A. and A. Sufi (2011), "House Prices, Home Equity-Based Borrowing, and the US Household Leverage Crisis", American Economic Review, Vol. 101/5, pp. 2132-2156, http://dx.doi.org/10.1257/aer.101.5.2132.

Mian, A. and A. Sufi (2008), "The Consequences of Mortgage Credit Expansion: Evidence from the U.S. Mortgage Default Crisis", SSRN Electronic Journal, http://dx.doi.org/10.2139/ssrn.1072304.

OECD (2019), Going for Growth 2019.

OECD (2019), OECD Economic Surveys: Denmark 2019, OECD Publishing, Paris, https://dx.doi.org/10.1787/eco surveys-dnk-2019-en.

OECD (2018), A Broken Social Elevator? How to Promote Social Mobility, https://doi.org/10.1787/9789264301085-en.

OECD (2018), A Broken Social Elevator? How to Promote Social Mobility, OECD Publishing, Paris, https://dx.doi.org/10.1787/9789264301085-en.

OECD (2018), OECD Regions and Cities at a Glance 2018, OECD Publishing, Paris, https://dx.doi.org/10.1787/reg_cit_glance-2018-en.

OECD (2018), "Suburbanisation and land-use within metropolitan areas", in OECD Regions and Cities at a Glance 2018, OECD Publishing, Paris, https://dx.doi.org/10.1787/reg_cit_glance2018-34-en.

OECD (2018), Taxation of Household Savings, OECD Publishing, Paris, http://dx.doi.org/10.1787/9789264289536-en.

OECD (2018), The Role and Design of Net Wealth Taxes in the OECD, OECD Tax Policy Studies, No. 26, OECD Publishing, Paris, https://dx.doi.org/10.1787/9789264290303-en.

OECD (2017), "Going for growth (Edition 2017)", OECD Economic Outlook: Statistics and Projections (database), https://dx.doi.org/10.1787/bdc23680-en (accessed on 21 January 2019).

OECD (2017), "Governing land use", in The Governance of Land Use in OECD Countries: Policy Analysis and Recommendations, OECD Publishing, Paris, https://dx.doi.org/10.1787/9789264268609-5-en.

OECD (2017), The Governance of Land Use in OECD Countries: Policy Analysis and Recommendations, OECD Publishing, Paris, https://dx.doi.org/10.1787/9789264268609-en.

OECD (2013), OECD Guidelines for Micro Statistics on Household Wealth, OECD Publishing, Paris, http://dx.doi.org/10.1787/9789264194878-en. 
OECD (2013), Pensions at a Glance 2013: OECD and G20 Indicators, OECD Publishing, Paris, http://dx.doi.org/10.1787/pension_glance-2013-en.

OECD (2010), Tax Policy Reform and Economic Growth, https://doi.org/10.1787/19900538.

[25]

OECD, P. (ed.) (2019), Links between Housing markets and economic resilience, OECD Economics department working paper, forthcoming.

Ortalo-Magne, F. and S. Rady (2006), "Housing Market Dynamics: On the Contribution of Income Shocks and Credit Constraints", Review of Economic Studies, Vol. 73/2, pp. 459-485, http://dx.doi.org/10.1111/j.1467-937X.2006.383 1.x.

Pence, K. (2006), "The Role of Wealth Transformations: An Application to Estimating the Effect of Tax Incentives on Saving", The B.E. Journal of Economic Analysis \& Policy, Vol. 5/1, http://dx.doi.org/10.1515/1538-0645.1430.

Pham-Dao, L. (2016), "Public Insurance and Wealth Inequality: A Euro Area Analysis", Annual Conference 2016 (Augsburg): Demographic Change 145942, Verein für Socialpolitik / German Economic Association.

Piketty, T. and E. Saez (2013), “A Theory of Optimal Inheritance Taxation”, Econometrica, Vol. 81/5, pp. 1851-1886, http://dx.doi.org/10.3982/ecta10712.

Rubin, D. (1987), Multiple imputation for nonresponse in surveys, Wiley, https://books.google.fr/books/about/Multiple Imputation for_Nonresponse in S.html? id=cNv TIOLs_WMC\&source $=\mathrm{kp}$ cover\&redir esc $=\mathrm{y}($ accessed on 21 January 2019).

Salvi del Pero, A. et al. (2016), "Policies to promote access to good-quality affordable housing in OECD countries", OECD Social, Employment and Migration Working Papers, No. 176, OECD Publishing, Paris, https://dx.doi.org/10.1787/5jm3p5gl4djd-en.

United Nations Economic Commision for Europe (2011), Canberra Group Handbook on Household Income Statistics Second Edition 2011, United Nations Economic Commision for Europe.

Vitale, C. et al (2019), THE 2018 UPDATE OF THE OECD PMR INDICATORS AND DATABASE, OECD.

Whelan, S. and S. Parkinson (2017), Housing tenure, mobility and labour market behaviour, Australian housing and urban research institute (AHURI), http://dx.doi.org/10.18408/ahuri7307101.

Wind, B. and C. Dewilde (2017), "Net worth and financial wealth among tenants and homeowners in 14 Eurozone countries with different institutional arrangements", HOWCOME Working Paper Series, http://www.tilburguniversity.edu/howcome.

Wolff, E. (2017), "Household wealth trends in the United States, 1962 to 2016: has middle class wealth recovered?", NBER working paper No. 24085.

World Bank (2018), Living and Leaving: housing, mobility and welfare in the European union, World Bank.

Xiong, Q. and A. Mavropoulos (2018), Housing Consumption and Macroprudential Policies in Europe: An Ex Ante Evaluation, http://www.iwh-halle.de. 